\title{
Can a Political Documentary Influence Foreign Policy Attitudes? The Agenda-Setting, Priming, and Framing Effects of CBC's Masters of Space.
}

\author{
By François Nadeau, B. Soc. Sci.
}

\author{
A thesis submitted to \\ the Faculty of Graduate and Post Doctoral Affairs \\ in partial fulfillment of the requirements for the degree of \\ Master of Arts \\ in \\ Political Science
}

Carleton University

Ottawa, Ontario

(C) 2011 François Nadeau 
Library and Archives Canada

Published Heritage Branch

395 Wellington Street Ottawa ON K1A ON4 Canada
Bibliothèque et

Archives Canada

Direction du

Patrimoine de l'édition

395, rue Wellington

Ottawa ON K1A 0N4

Canada
Your file Votre référence

ISBN: 978-0-494-81640-0

Our file Notre référence

ISBN: 978-0-494-81640-0
NOTICE:

The author has granted a nonexclusive license allowing Library and Archives Canada to reproduce, publish, archive, preserve, conserve, communicate to the public by telecommunication or on the Internet, loan, distribute and sell theses worldwide, for commercial or noncommercial purposes, in microform, paper, electronic and/or any other formats.

The author retains copyright ownership and moral rights in this thesis. Neither the thesis nor substantial extracts from it may be printed or otherwise reproduced without the author's permission.
AVIS:

L'auteur a accordé une licence non exclusive permettant à la Bibliothèque et Archives Canada de reproduire, publier, archiver, sauvegarder, conserver, transmettre au public par télécommunication ou par l'Internet, prêter, distribuer et vendre des thèses partout dans le monde, à des fins commerciales ou autres, sur support microforme, papier, électronique et/ou autres formats.

L'auteur conserve la propriété du droit d'auteur et des droits moraux qui protège cette thèse. $\mathrm{Ni}$ la thèse ni des extraits substantiels de celle-ci ne doivent être imprimés ou autrement reproduits sans son autorisation.
In compliance with the Canadian Privacy Act some supporting forms may have been removed from this thesis.

While these forms may be included in the document page count, their removal does not represent any loss of content from the thesis.
Conformément à la loi canadienne sur la protection de la vie privée, quelques formulaires secondaires ont été enlevés de cette thèse.

Bien que ces formulaires aient inclus dans la pagination, il n'y aura aucun contenu manquant. 


\section{Abstract}

Despite their rising popularity in recent years, political documentaries have been overlooked by communication scholars as a source of influence on public opinion. The current study addresses this gap in the literature by examining the agenda-setting, priming, and framing effects of the CBC documentary Masters of Space. A quasi-experiment reveals that Masters of Space has both agenda-setting and framing effects on viewers, while no conventional priming effects are detected. In particular, the documentary seems to raise perceptions that space weaponization and nuclear proliferation are important issues and that satellites are important to one's personal way of life. Viewing the documentary also sparks opposition to Canada's involvement in missile defence, while increasing support for Canada-United States cooperation on space debris tracking. Finally, the film appears to convince viewers that America's space policy is aggressive towards other countries. These findings show that political documentaries do not only educate and entertain; they can influence foreign policy attitudes. 


\section{Acknowledgements}

It is a pleasure to thank all those who helped and inspired me to write this thesis. I owe my deepest gratitude to Dr. Scott E. Bennett for teaching me the fundamentals of multivariate statistics and for helping me understand the nature and malleability of public opinion. I am also grateful to Dr. Elinor Sloan, whose lectures on Canadian defence policy and strategic thought inspired me to study the issue of space security.

Moreover, this study would not have been possible without the assistance of my dear colleagues Lesley Copeland and Myles Hulme, who kindly allowed me to survey their students as part of this experiment. My gratitude equally extends to their students, who agreed to watch the documentary and to fill out the surveys. My thanks go out as well to the Department of National Defence for awarding me with a scholarship through the Security and Defence Forum.

Finally, I thank family members for all their support throughout the years. I thank my parents for being there when it mattered most and for helping me to pursue my interest in scholarly work. I could not have achieved this without you. I thank my loving wife Julia for putting up with my somewhat bohemian lifestyle and appearance these past few months. And last, but not least, I dedicate this study to my newborn son Galen, whose affectionate little smile has gotten me through the most stressful of times. 


\section{Table of Contents}

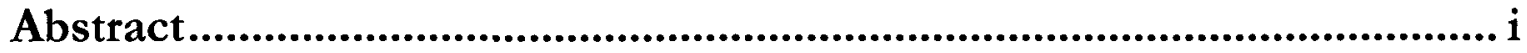

Acknowledgements .......................................................................... ii

Table of Contents ............................................................................iii

List of Tables ................................................................................................

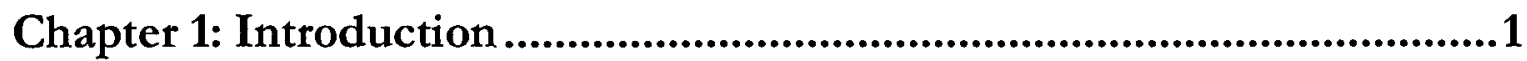

Chapter 2: CBC's Masters of Space .........................................................4

Background Information ............................................................................................4

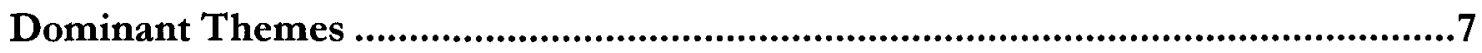

Importance of Satellite Technology ...................................................................... 7

Dual-use Nature of Space Technology ................................................................ 9

The Aggressiveness of America's Space Policy ..................................................... 15

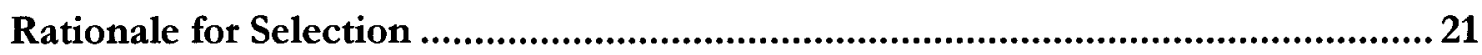

Chapter 3: Literature Review ............................................................24

Agenda-Setting Effects ...........................................................................................24

Second-Level Agenda-Setting Effects...........................................................................30

Priming Effects ...........................................................................................................32

Framing Effects................................................................................................36

Core Values and Beliefs ...........................................................................................42

Chapter 4: Methodology ............................................................................44

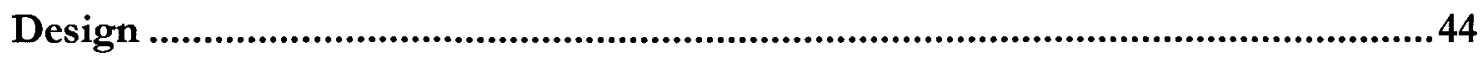

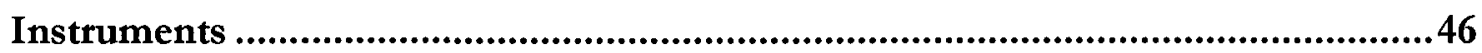

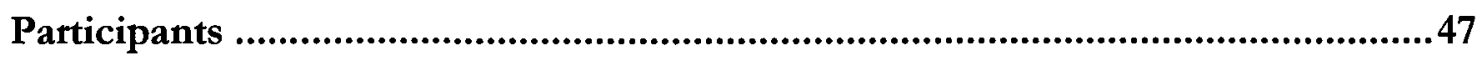

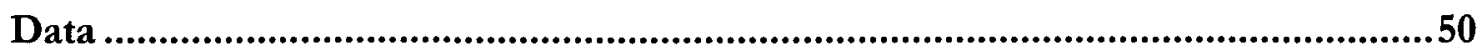

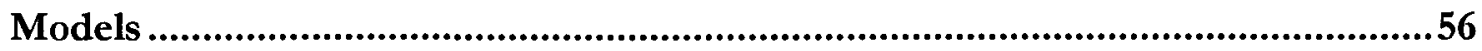

Chapter 5: Results ........................................................................61

First and Second-Level Agenda-Setting Effects (Hypotheses 1 and 2)................... 61

Priming Effects (Hypothesis 3) .............................................................................64

Framing Effects (Hypotheses 4 and 5) ...................................................................67

Chapter 6: Conclusion .............................................................................78

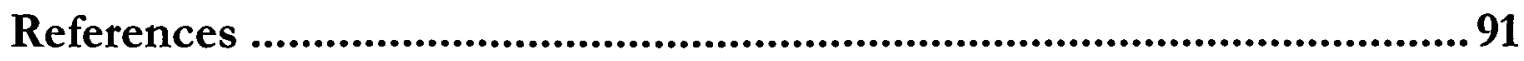


Appendix A: Letter of Information (Control Group)............................98

Appendix B: Letter of Information (Treatment Group) .........................100

Appendix C: Pre-Test Questionnaire ..................................................... 102

Appendix D: Post-Test Questionnaire ............................................. 105

Appendix E: Ethics Clearance Form ..................................................... 109

Appendix F: Regression Output from SPSS ........................................ 110 


\section{List of Tables}

Table 1.1: Comparison of background characteristics of treatment group and control group respondents

Table 1.2: Comparison of scores on dependent variables at $1^{\text {st }}$ measurement

between treatment group and control group and control group

participants

Table 1.3: Descriptive statistics for dependent variables at $1^{\text {st }}$ and $2^{\text {nd }}$ measurement for all participants

Table 2: Regression predicting the perceived importance of security issues and issue attributes

Table 3: Regression predicting attitudes about President Obama based on his perceived commitment to banning weapons in space

Table 4.1: Regression predicting opposition to Canadian participation in the development of a missile defence shield

Table 4.2: Regression predicting opposition to Canadian participation in the development of a foreign satellite tracking system

Table 4.3: Regression predicting opposition to Canadian participation in the development of a space debris tracking system

Table 4.4: Regression predicting opposition to Canadian participation in the development of micro-satellite technology

Table 5: Regression predicting perceived aggressiveness of America's space policy towards other countries 


\section{Chapter 1: Introduction}

For most citizens, the mass media is a primary source of information about foreign policy issues (Jordan \& Page, 1992; Seaver, 1998; Soroka, 2003). The media, as the term implies, both mediates and moderates the flow of information between policy elites and the mass public. Not long ago, news media was a far more cohesive enterprise in society. Newspapers, radio, and television were among the only sources of news people could turn to for information about the world beyond their borders. However, new forms of media have now begun to appear in society and they are rapidly changing the way people search for and obtain information about international affairs. Consequently, these changes may also be affecting the type of information people are exposed to and the effects this information has on their foreign policy attitudes.

Scholars have long been interested in studying the way media content influences public opinion. Early pioneers of this research focussed on the ways news media influences which issues people think about and how frequently they think about them. They labelled this effect as agenda-setting (see McCombs and Shaw, 1972). This gradually gave way to research examining the media's role in deciding which criteria people use to judge political elites. The news media, some scholars argued, influences what information we use to form our opinions about politicians by simply making that information more readily accessible in memory. They labelled this effect as priming (see Iyengar and Kinder, 1987). Today, scholars are more inclined to examine how the media presents certain issues and whether that presentation influences how viewers then think about those issues. They label these outcomes as framing effects (Weaver, 2007). Framing, they argue, involves highlighting some aspects of an issue while omitting others in the process (see Entman, 1993). Yet despite this 
gradual evolution in media effects research, most of the literature has remained focussed almost exclusively on the impact of news media.

Surprisingly, one source of information about foreign policy issues that has been overlooked in recent years is the political documentary (Nisbet \& Aufderheide, 2009). Documentary film making has become a highly lucrative industry for many film-makers such as Michael Moore and Denis Delestrac and films like Fabreinbeit 9-11, An Inconvenient Truth, and Inside Job are increasingly being praised by critics as 'eye opening' and 'insightful.' The internet has also allowed amateur film-makers espousing radical world views to disseminate their low-budget documentaries to the masses on web sites like YouTube and Veoh. Filmmaker Peter Joseph, for instance, gained notoriety for his on-line documentary Zeitgest, which alleges that the $9 / 11$ attacks on the World Trade Center were orchestrated by the United States government. In fact, a number of web sites and television stations, including CBC's Doc Zone and $C B C$ News World in Canada, now air political documentaries free of charge to the public. The rate at which these films are being produced and disseminated and the messages they deliver raise an important question: can they actually influence public opinion? Studies have found that documentaries in general can have numerous effects on viewers. In the early days of public affairs broadcasting, television documentaries were found to re-enforce existing attitudes towards issues by providing viewers with a sense of closure about positions advanced in these films (Fitzsimmons \& Osburn, 1968). More recently, a number of studies have examined the impact of documentary film on attitudes towards climate change. Al Gore's 2006 documentary An Inconvenient Truth was found to increase knowledge about, concern for, and willingness to reduce, green house gases (Nolan, J. M., 2010). Conversely, a polemic documentary framing the climate change movement as the greatest "swindle" in history caused viewers to question conventional beliefs in man-made 
global warming (Bennett, 2010). Studies have also examined the impact of documentaries on environmental sensitivity (Barbas et al., 2009), attitudes towards schizophrenics (Penn et al., 2003), levels of issue interest and affective learning (LaMarre, H. L., 2009), as well as the ideological implications of using documentary films to teach controversial events in history (Stoddard, J. D., 2009). Yet despite scholarly interest in documentaries, no study to date has examined the effects of documentary film on attitudes towards foreign policy issues.

This quasi-experimental study extends the literature on agenda-setting, priming, and framing effects to the study of political documentaries. Chapter 2 provides a brief summary of the CBC documentary Masters of Space, used here as an experimental treatment, and identifies three dominant themes based on the film-maker's personal views. Chapter 3 provides a review of the literature on agenda-setting, priming, and framing effects and relates these theories to the major themes identified in the film. Chapter 4 describes the experiment in detail while Chapter 5 presents the results from a test of five hypotheses. Of interest here is the documentary's impact on attitudes towards outer space security issues. Chapter 6 concludes with a discussion about the findings and the limitations of this study. In the end, the findings reveal that while political documentaries are often considered educational and entertaining, they can also influence political attitudes towards foreign policy issues. 


\section{Chapter 2: CBC's Masters of Space}

By way of introduction, this study begins with a brief summary of the $\mathrm{CBC}$ documentary Masters of Space. Some background information is provided concerning the film's producer and his source of inspiration. Three dominant themes are then identified in the film based on the views expressed by the film-maker himself during several media interviews. These three themes include: the importance of satellite technology in society; the dual-use nature of space technology; and the aggressiveness of America's national space policy. 'This section ends with a brief rationale for selecting the film.

\section{Background Information}

Masters of Space is a made-for-television version of the full length documentary Pax Americana and the Weaponization of Space. The film was written and directed by French-born Canadian film-maker Denis Delestrac. The full length documentary was first screened at numerous international film festivals in 2009 before being officially released in Canadian theatres in June 2010. Mark Achbar, director of the 2004 documentary The Corporation, served as executive producer and also financed the film with a performance envelope he received from Telefilm Canada, a Crown Corporation owned by the Canadian government (Anderson, 2010). The film was also produced in collaboration with the Canadian Broadcasting Corporation (CBC) and Radio Canada.

Delestrac was inspired to write the film after having a telephone conversation with linguist and political activist Noam Chomsky. As he recalls: "I was talking with him about nuclear terrorism and he told me that there is a much more imminent threat....That was the 
weaponization of space" (Anderson, 2010). Like Chomsky, Delestrac believes that the media is spreading elite propaganda in society and he argues documentary filmmakers like him must address this problem. As he puts it:

Too often, the media we trust to get informed are - purposefully or not - relaying institutional propaganda with the terrible consequences we've all seen in Iraq for example. One of the responsibilities of documentary filmmakers is to fill this gap, to shed some light on the important challenges of today's society, and the weaponization of space is undoubtedly one of them (Pax Americana, 2010).

To fill this particular gap, Delestrac applied for, and obtained, access to United States Air Force (USAF) bases along with permission to interview members of the military establishment. Film crews mostly shot footage of Cadets training at the USAF Academy in Colorado Springs and this footage was later used in both the original and the $\mathrm{CBC}$ versions of the documentary.

Delestrac's documentary is political in nature. The documentary is not only meant to inform viewers about space security issues, but also to motivate them into taking action and publicly opposing the weaponization of space. When asked whether he worried people would be overwhelmed by yet another documentary revealing a problem in society, Delestrac responded:

The world is falling apart and the environment and nuclearization and food and water, and now space $[s i c]$. Come on. But I think it needs to be on the radar screen for people. Yes, it's difficult to raise attention and to go further than watching a film. 
My hope is that people are going to go a step further and sign a petition and organize a screening, things like that (Stone, 2010).

Delestrac's documentary is not only intended to raise awareness about the issue, but also to provoke action. Delestrac thinks of himself as an activist with a message after having worked on the film for five years (Stone, 2010). Shortly after the film's release, he helped activists organize Space for Peace Week in October 2010, an event sponsored by an American organization called the Global Network against Weapons and Nuclear Power in Space'. Incidentally, many of the American activists appearing in the $\mathrm{CBC}$ documentary, including Bruce Gagnon, Loring Wirbel, and Karl Grossman, are affiliated in some capacity with this organization.

Delestrac's documentary was later edited for use by the $\mathrm{CBC}$. The $\mathrm{CBC}$ version was aired on the television program The Nature of Things (CBC, 2010b). The CBC version is 44 minutes long and it is narrated by host David Suzuki. Although the CBC version is significantly shorter than the full length documentary, it presents many of the same interviews and maintains a similar tone and structure. The $\mathrm{CBC}$ version, entitled Masters of Space, is currently sold as an educational video on the CBC Learning web site under the heading 'Politics and Government', where it is advertised as a teaching aid for secondary and post-secondary students. Masters of Space has also been publicly accessible on YouTube.com since 28 August 2010, where it was accessed and used for this experiment.

${ }^{1}$ see http://www.space4peace.org/sales.htm. 


\section{Dominant Themes}

To assess the documentary's impact on attitudes and perceptions, it is necessary to identify some of the dominant themes transmitted through the film. Here, three themes are identified based on what Delestrac himself emphasized in media interviews while promoting the film. These themes include: the importance of satellite technology; the dual-use nature of space technology; and the aggressiveness of America's national space policy. This subsection provides a brief summary of how these themes surface in the film.

Importance of Satellite Tecbnology The first of these themes concerns the importance of satellite technology for personal well-being and national security. When asked by one critic to mention the most surprising thing he learned from his research, Delestrac answered:

Every step I took in this research opened another door that confirmed this subject was really urgent and really important. For example, I had no idea when I started that so many of the orbiting satellites are owned by the U.S. I did not realize at all that we use them every day. Things like that. On the military side, I was very surprised to learn how the military depends on space (Stone, 2010).

Accordingly, Masters of Space opens with a segment emphasizing the importance of satellite technology in society. Theresa Hitchens, director of the Center for Defense Information (CDI), argues that satellites are crucial to every-day life. As she puts it: "our entire life depends on satellites. They are essential. But we are not conscious of that until we 
lose 1t" (CBC, 2010a). She argues that most civillans are unaware of how much they rely on satellite technology in their day-to-day lives. Satellites, she notes, are used whenever a person opens a cell phone, withdraws money from the bank with an ATM card, watches television programming from around the world, relies on a GPS system to get directions, and follows the weather forecast in the news Suzukı then provides statistics showing that the United States is 'the master of space' because its use of satellite technology far exceeds that of any other country. Of the 1000 satellites currently orbitung the Earth, he notes, the United States owns nearly $50 \%(48.9 \%)$. These are evenly divided between civllan satellites $(24.5 \%)$, owned largely by telecommunication companies and used for ctvilian purposes, and dedicated military satellites $(24.5 \%)$.

Viewers are then informed about the American military's dependence on satellite technology Robert J. Stevens, CEO of the Lockheed Martin Corporation, is shown giving a speech at the $23^{\text {rd }}$ National Space Symposium. Stevens claims that space is "the backbone of [Amenca's] national security" and that there is "no alternative to military dominance in outer space" for America (CBC, 2010a). The United States, and its intelligence services in particular, are highly concerned about the vulnerability of their satellites in low Earth orbit ${ }^{2}$. The Chinese could cripple the United States military by launching a surprise attack in space and disabling as few as 50 dedicated military satellites. Doing so, it is argued, could prevent the United States military from communicating effectively with its forces and potentially blind the intelligence community, which relies on satellite imagery to monitor military force movements around the world. "Without space," one expert notes, "the U.S. would be unable to conduct any type of military operation in an effective way" (CBC, 2010a). Taken together,

${ }^{2}$ Low Earth Orbit (LEO) ranges from approxımately $180 \mathrm{~km}$ to $2,000 \mathrm{~km}$ above the Earth's surface 
the importance of satellite technology for civilian and military use is a central theme in the CBC documentary Masters of Space.

Dual-use Nature of Space Technology Another important theme in this documentary is the issue of dual-use space technology. Here, Delestrac intends to show that different types of space technology can be used for either benign or belligerent purposes. The systems he highlights include, among others, missile defence, space surveillance, and micro-satellites. In one interview, for instance, Delestrac claims:

It's very easy to think that missile defence is really about defence or that a military satellite is only there to observe....But as we say in the film, there's the issue of dual use. We can make a very simple comparison with a hammer - you can use a hammer to build a house or you can use a hammer to torture and kill somebody. But you're not going to prohibit hammers in stores (Anderson, 2010).

Accordingly, Delestrac's documentary emphasizes how American space technology could be used to attack foreign-owned satellites. In particular, the documentary is highly critical of ballistic missile defence (BMD). Since the film does not distinguish BMD from previous missile defence programs such as the Strategic Defence Initiative (SDI) or National Missile Defence (NMD), a brief clarification is provided below.

BMD is designed to locate, track, intercept, and destroy intercontinental ballistic missiles (ICBMs) during various stages of an attack. Tested and deployed by the second Bush Administration, the system is a layered version of the National Missile Defence (NMD) system introduced under the Clinton Administration. Like NMD, BMD is designed to 
protect the continental United States from deliberate or accidental launch of a small number of nuclear missiles by China, Russia, and smaller rogue states. The system has been expanded to provide coverage to American allies overseas, as well as to allied forces deployed abroad (Sloan, 2005).

The program currently consists of three operational components: land-based, seabased, and theater-based defence. The land-based component, called Ground-Based Midcourse Defence (GMD), is designed to intercept and destroy long-range ballistic missiles while they travel through low Earth orbit (midcourse phase) en route to their target. The seabased component, called Aegis Ballistic Missile Defence, consists of missile interceptors mounted on naval warships (Ticonderoga class missile cruisers). These are designed to intercept and destroy short, medium, and intermediate-range missiles in all three stages of flight: ascent, midcourse, and terminal (re-entry). A third layer, Terminal High Altitude Area Defense (THAAD), is a mobile ground based platform carrying similar hit-to-kill interceptors designed to destroy incoming missiles during their descent.

These systems, developed under the guidance of the Missile Defence Agency (MDA), fall under the purview of the United States Strategic Command (STRATCOM). STRATCOM is responsible for battle management of the system. It also gathers information from anti-ballistic missile early warning satellites (BMEWS) and space surveillance networks and channels it to NORAD for interpretation and assessment.

BMD, which integrates sensors, weapons, and command capabilities, is designed to function as follows. Radars and satellites identify incoming targets and relay the information to land and sea-based operating platforms. Interceptor missiles are then launched from these platforms en route to the incoming missile. As it approaches its target, during a period of twenty minutes or so, a kinetic hit-to-kill vehicle separates itself from the booster and travels 
directly into the missile's path by tracing its heat signature ${ }^{3}$. The kill vehicle is designed to collide head-on with its target and thereby neutralize the threat. These three systems have been proven effective when tested under optimal conditions and the results have been improving steadily for both land and sea based components over the past decade (Harvey, 2000; Boese \& Pomper, 2005; Fergusson, J. G., 2010).

Yet despite these developments, Delestrac's documentary provides a very narrow depiction of missile defence. As Delestrac argued in his interview: "a lot of people think that 'Star Wars' is past, is finished.... That's part of my reason for making the film, to say it's not finished and it's always been there" (Anderson, 2010). In keeping with this view, Suzuki, the narrator, traces the origins of BMD back to Ronald Reagan's Strategic Defense Initiative (SDI), a far more ambitious research program investigating the feasibility of deploying x-ray lasers and missile interceptors in space to neutralize an entire Soviet arsenal. Footage from a televised debate in the 1980s shows planetary astronomer Carl Sagan arguing that SDI cannot work and can be overwhelmed and outfoxed by a large scale Soviet attack. Suzuki claims that 'Star Wars' (SDI) re-surfaced as 'missile defence' under the Bush Administration in 2000. Footage is shown of President George W. Bush announcing America's withdrawal from the ABM Treaty with Russia, which subsequently allowed the United States to test and deploy missile defence. These scenes are fashioned together to give viewers the perception that Ballistic Missile Defence is the Strategic Defence Initiative, even though the two programs differ significantly in scope and objectives.

Next, the President of Ploughshares Joseph Cirincione argues that the threat of nuclear weapons is declining and that there are far fewer nuclear missiles in the world today

\footnotetext{
${ }^{3}$ The device used to intercept an incoming ballistic missile is called an exoatmospheric kill vehicle (EKV) The EKV is a $14 \mathrm{~m}$ long cylindrical device equipped with a long range electro-optacal infrared sensor to detects incoming missiles (Jane's, 2010).
} 
than there were fifteen years ago. He adds that there are fewer hostile countries towards the United States possessing ballistic missile programs. Iran and North Korea, the only two real threats, lack the intercontinental ballistic missiles (delivery systems) required to launch a nuclear assault on North America. This leads Cirincione to conclude that missile defence "is the longest running fraud in the history of the U.S. Department of Defense" (CBC, 2010a). Building on this argument, Suzuki questions whether "missile defence [is] another way of funding space weaponry" (CBC, 2010a). Here, he points out that the United States conducted its own anti-satellite weapons test in 2008 using a modified missile defence interceptor to shoot down one of its own satellites in low Earth orbit. In doing so, he implies the possibility that missile defence is really a "Trojan horse" for space weaponization.

Interestingly, the documentary offers no clear definition of missile defence and overlooks BMD's capabilities and limitations. It also fails to point out that missile defence technology has evolved out of SDI research and that it presently has a much narrower application to continental defence. Instead, the film frames BMD as 'Star Wars' (SDI), emphasizes statements about its futility, and depicts the system as part of an anti-satellite weapons program in disguise.

Moreover, the documentary questions President Barack Obama's commitment to banning weapons in space. Suzuki recalls how there was hope that Barack Obama would prevent the weaponization of space when he took office in 2009 by "seeking a ban on weapons that interfere with military and commercial satellites," according to a White House memo (CBC, 2010a). Suzuki notes, however, that "the Obama Administration's 2010 defence budget requested close to a billion dollars that was applicable to space warfare systems," including “a new program called offensive counterpace," defined by the Defense 
Department as “offensive measures to disrupt, deny, degrade, or destroy any adversary's space capabilities" (CBC, 2010a).

Meanwhile, the documentary provides a far more ambiguous depiction of satellite tracking and navigation technology. According to Suzuki, "trying to track down what the Defence Department is spending on space weapons projects is a tricky business" (CBC, 2010a). He cites the USAF's research on laser technology as an example. The Starfire optical laser system has been used in the past to research satellite tracking capabilities. However, Air Force budget documents recently mentioned use of Starfire as a potential anti-satellite weapon. Hitchens explains that the Air Force is attempting to narrow its experimental laser beam and project it onto a satellite in space. She questions the Air Force's denial of antisatellite testing with Starfire claiming a narrow beam is less effective than a wider beam for tracking stars. Hitchens claims she and her colleagues worry that Starfire "is actually an antisatellite weapons test in disguise" (CBC, 2010a).

The film also raises concerns about micro-satellite technology. The XSS-11 microsatellite, tested in April 2005, is depicted as having the ability to disrupt other nations' satellites. They can help scientists diagnose problems with larger satellites by effectively navigating around them and taking pictures. Hitchens warns, however, that those same micro-satellites could theoretically be used as projectiles to destroy the satellites of other countries.

Talk of destroying satellites leads to a segment about space debris. Suzuki mentions that "blowing up satellites - your own or someone else's - has very physical consequences..." (CBC, 2010a). Destroying another country's assets in space can create debris that interferes with and threatens one's own assets in space. Suzuki mentions "there are roughly 600,000 pieces of our space garbage currently orbiting the Earth" (CBC, 2010a). 
These objects travel at 14,000 mules per hour with the equivalent force of a cannonball.

NASA, according to Hitchens, is concerned about losing its ability to conduct operations in low Earth orbit "because the [debris] that is already up there will start breaking up and creating more and more clutter" (CBC, 2010a).

Interestingly, the emphasis then shifts to the harmful effects of America's antisatellite test in 2008. "One year after the Chinese anti-satellite test," Suzukı says, "the U.S. destroyed one of its own satellites in orbit. These kinds of tests risk increasing the amount of space garbage" (CBC, 2010a). The segment concludes with a warnıng that placing weapons in space risks creating debris that could jeopardize billions of dollars of satellite technology in orbit.

It should be noted here that Suzuk1's statement is somewhat misleading. Unlike the Chinese, the Americans deliberately destroyed their satellite (USA-193) at an altitude of 247 $\mathrm{km}$ to ensure that over 99 percent of the debris generated would re-enter the Earth's atmosphere and disintegrate shortly after the interception (Liemer \& Chyba, 2010). By comparison, the Chinese anti-satellite test was conducted at $864 \mathrm{~km}$ in altitude and produced thousands of debris fragments in orbit now lodged at between 800 and $1000 \mathrm{~km}$ in altitude. Surprisingly, Suzuki and the documentary do not highlight this difference, nor the amount of space debris China produced after its test. Instead, Suzuki uses the American test as an example of how anti-satellite testing produces space debrrs.

\footnotetext{
${ }^{4}$ Here, Hitchens is likely referring to Kessler's Syndrome, a theory advanced by NASA scientist Donald J Kessler in the 1970s (see Kessler \& Cour-Palats, 1978) The theory asserts that as space becomes increasingly crowded with artuficial satellites, the probability of collisions between these satellites will rise Each collision could produce fragments that could, in turn, collide with other satellites and fragments (including debris-on-debris) This chain reaction would eventually produce a belt of debris around the Earth that would threaten NASA's operations in low Earth orbit The theory has often been cited by scientists and activists However, the documentary does not mention active debris removal (ADR) techniques being examıned by NASA Ironically, one promising technique involves ground and space-based lasers that could, when fired on a prece of debris repeatedly, lower its orbital altutude and cause it to de-orbit into the Earth's atmosphere (Weeden, 2011)
} 
The Aggressiveness of America's Space Policy Yet another important theme in this film is the idea that America's national space policy is aggressive towards other countries. When asked about the purpose of the film during an interview, Delestrac told a reporter:

I wanted to go beyond the clichés and make a clear inventory of what's really happening over our heads. And after three years of investigation, the conclusions were both surprising and alarming: the United States, who own more satellites than the rest of the world combined, are pursuing a space control policy which aims at denying access to space to other nations and controlling the Earth from the high ground' of space (Lupick, 2010).

To this end, the documentary presents numerous complaints from peace activists, scientists, and foreign experts that America's actions are prompting a global arms race in outer space. First, America's space policy is framed as a means of establishing an empire on Earth. The film opens with Suzuki questioning to what extent satellites and space debris are connected to military ambitions in space. Later, a preacher is seen giving a speech to young Air Force cadets about the similarities between America and ancient Rome. Hitchens explains that 'Pax Americana', the theme of that sermon, "is a political view which...says that because America is currently the sole superpower, that it has not only the ability, but the responsibility into the far future to maintain world peace” (CBC, 2010a). The United States, she argues, is in a good position to establish an empire that will survive several decades into the future. Asserting control over space, she claims, is a way for the United States to achieve this objective. 
The focus then shifts to how the United States is conducting its military operations in space. Frank Gaffney, a one-time Assistant Secretary of Defense under the Reagan Administration, explains that:

There is a tremendous premium on the United States being able to prevent other people from attacking our assets in space and to ensure that we can contunue to exercise full use of them and, if necessary, also to be able to deny others the use of similar assets for their own purposes (CBC, 2010a).

Gaffney's comment prompts a closer look at the next generation of A1r Force cadets trained to defend American space assets. Air Force cadets are pictured in a classroom wearıng battle dress uniforms (army fatigues) and Cadet First Class (C1C) Colton Tuttle is heard saying "in military strategy, it shows that if you want to control the battlefield, you need to be the first in seizing the high-ground....So, making sure that we can deny our enemies space is a huge advantage" (CBC, 2010a). These comments by Gaffney and Tuttle set the stage for a lengthy and negative portrayal of America's actions in outer space over the past 50 years.

A significant portion of the film depicts how the United States recruited former Nazi scientrst Werner Von Braun to work on NASA's rocket propulsion systems at the onset of the Cold War ${ }^{5}$. The documentary traces the origins of space weaponry back to Nazi Germany's V2 missile, used extensively against London during World War II. While showing

\footnotetext{
5 Von Braun, a German aristocrat by birth, had little sympathy for the Nazis and considered the movement vulgar (Burrows, 1998) According to Burrows, his devotion to rocketry was not 1deological, but rather was rooted in a genuine destre to bring about manned space exploration Though Von Braun was fully aware of the practical consequences of his research during World War II, he worked with the Nazis to "milk the military purse" to fund his personal research (Burrows, 1998 79) This Faustian deal would forever haunt Von Braun (Ibid) This information is omitted from the documentary
} 
footage of Hitler and Nazi scientists attending a launch, Suzuki describes how Von Braun, the chief engineer on the project, "sparked interest across the Atlantic" in ballistic missiles (CBC, 2010a). The V2 and its engineers were sought after by both the Americans and the Russians immediately after World War II. Von Braun and hundreds of his best engineers were recruited by the United States to build an improved version of the V2 and Von Braun eventually became the Associate Director of NASA ${ }^{6}$. Karl Grossman, a journalism professor, argues that these scientists (Nazi collaborators) began looking at space as a new arena of war. Footage from a speech Von Braun gave to military officers on 20 October 1955 is displayed and shows Von Braun describing how space could serve as a platform for dropping bombs on Earth. These images re-enforce the idea that America pursued military ambitions in space.

During the segment on missile defence, Suzuki and a number of activists frame the United States as intent on dominating space and denying other countries access to it. Space activist Bruce Gagnon quotes the United States Space Command's Vision 20/20 report released in 1998 as evidence that the United States is actively seeking to control, dominate, and deny other countries access to, space. Suzuki argues that "in making their claim to dominate space, the Americans have staked a mysterious new battle ground" (CBC, 2010a). The discussion slowly turns to the weapons the United States is allegedly developing to achieve this objective. These include, notwithstanding missile defence, an orbiting space plane (Falcon $\mathrm{H}^{\prime} \mathrm{TV}-3 \mathrm{X}$ ) that could manoeuvre rapidly and fire weapons at ground-based targets and satellite-based missiles that would "park weapons in space" and drop them on Earth-

\footnotetext{
${ }^{6}$ According to one reporter, "Delestrac suggests that one reason why this history has remained far from public view is that NASA is so 'great at PR"' (Anderson, 2010) Interestungly, NASA did onginally conceal the military, Naz1, and S S backgrounds of these German scientists to make them more "palatable" to the public (Moltz, 2008)
} 
bound targets (CBC, 2010a). The orbital bombardment system, Suzuki warns, could be as devastating as nuclear weapons.

Finally, the United States is framed as the unjust aggressor, while countries like China are framed more as victims of American hegemony. First, activist Bruce Gagnon alleges that the American government is deliberately deceiving the people into believing countries like China and North Korea pose a threat. He claims, for instance:

The Pentagon has said that moving the arms race into space will be the largest industrial project in the history of the planet Earth. They can't take any chances. They have to have an enemy. They have to make the people afraid: 'Someone's going to attack us with nuclear weapons'; We've got to have missile defence in order to protect us from attack.'. 'Iraq', one of the rogue states... 'Iran'... 'North Korea'... and now they throw China into that equation.... (CBC, 2010a).

Then, another activist, Loring Wirbel, follows with a similar comment:

"For the last three years," he claims, "the Pentagon has been trying to make China the new 'boogeyman' and China unwittingly played into the United States' hands with its anti-satellite test" (CBC, 2010a).

Here, China is framed as a kind of victim of American stereotyping despite its own testing of an anti-satellite weapon in 2007 . The documentary obfuscates the issue by revealing that the United States knew China was conducting the test even before China 
launched its missiles. The United States, it is argued, has reconnaissance and surveillance satellites that can detect every launch of a missile.

In the end, the documentary depicts the United States as pursuing an aggressive unilateral space policy that threatens the security of other nations. The discussion shifts towards the need for a United Nations treaty banning space weapons. Here, Noam Chomsky points out that the United States has repeatedly voted down efforts by other countries to renew and extend the Outer Space Treaty at the Conference on Disarmament. That treaty only bans placing nuclear weapons in space. Wirbel argues that a treaty alone is not enough. Rather, countries "should work on international treaties to make...military space networks used for multi-lateral purposes" (CBC, 2010a). Obama's willingness to ban space weapons is questioned because of his funding of counter-space warfare programs and claims are made about the unlikelihood of America giving up its imperial ambitions. These scenes re-enforce the perception that America is determined to weaponize space at all costs.

The film concludes with a warning that countries will have no choice but to develop their own space defences if the United States does so first. According to Suzuki, "it is probable that more countries will decide that their space programs must also be used for national defence" (CBC, 2010a). Japan, for instance, recently lifted its ban on the military use of space and Iran is pursuing an ambitious space program of its own. The European Community, one French expert warns, will also need to consider ways of defending its interests in space "if the Americans continue not only to place military satellites, but also weapons in space" (CBC, 2010a). And Russia, Suzuki warns, "has threatened to develop counter-measures to destroy any orbiting threat" (CBC, 2010a). But Noam Chomsky`s statement is perhaps the most alarming of all. He warns that "if we move to the weaponization of space, we can bid farewell to the planet. The chances of survival are very 
slight" (CBC, 2010a). Indeed, the popular consensus among these experts appears to be that America's space policy is provoking other countries to develop their own space-based defences. This, they argue, could have a catastrophic impact on the world. Taken together, the final 14 minutes of footage depict a very negative and aggressive image of the United States and its national space policy. 


\section{Rationale for Selection}

Masters of Space was selected as a case study because it provides a unique opportunity to gauge how future generations might react to space security issues in the media. The documentary, for instance, explores the highly contentious issue of missile defence; a topic that some argue may re-surface in Canadian politics. The issue has been the source of at least two major controversies in Canada since the 1980 s. In 1985, Brian Mulroney declined government-togovernment participation with the United States in Ronald Reagan's Strategic Defence Initiative amidst flerce opposition from politicians, academics, and activists in the media. Then, in 2004, Paul Martin turned down an offer from George W. Bush for Canada to actively participate in Ballistic Missile Defence under similar circumstances ${ }^{7}$.

In both cases, opponents framed support for SDI and BMD as violating Canada's position on outer space security at the United Nations (Fergusson, 2010). These critics pointed out that both programs would eventually rely on interceptors in space to neutralize incoming ballistic missiles. This, they charged, would violate the principles set forth in the Outer Space Treaty of 1967. Proponents, meanwhile, argued that the treaty only prohibits the deployment of nuclear weapons in orbit and neither prohibits conventional weapons in space nor the lawful use of force in space ${ }^{8}$.

Moreover, though it has repeatedly voiced opposition to the militarization of space since 1967, Canada, some pointed out, had previously developed its own military space program including launch capabilities in the 1950 s. It had participated in continental space programs with the United States during the 1960 s to explore the possibilities of space

\footnotetext{
7 Paul Martin did not attribute his decision on BMD participation to public criticism in his memoirs, clarming instead that he declined the offer mainly because he could not obtain re-assurances that Canadian cities would be defended durng a large scale nuclear attack (see Martin, 2008) However, many anti-missle defence activists believe their efforts to mobilize public opposition (especially through the media) contributed to Martin's decision (see Staples, 2006)

${ }^{8}$ For a legal interpretation of the Outer Space Treaty, see Gleeson, 2007.
} 
surveillance, ballistic missile early warning, space-based communication networks, and satellite navigation. Godefroy (2006) even argues that "there was no reluctance on the part of Canada to militarize or weaponize space; in fact, the record suggests that if further resources had been available a higher profile effort may have resulted" (331). The dismantling of Canada's military space programs, he notes, only began under the Trudeau government in 1968, which saw no distinction between placing military 'assets' in space and placing 'weapons' in space (Godefroy, 2000). Proponents thus point out that the anti-space weaponization arguments against participating in SDI and BMD have been founded primarily on the Trudeau government's restrictive interpretation of the Outer Space Treaty. Fergusson (2010) argues Canadian policy-makers could once again be faced with an American offer to participate in BMD, prompting yet another national debate on the issue. Future presidential administrations could conceivably test and deploy a final layer of spacebased kinetic-kill interceptors to defend the continent and protect essential military, civilian, and commercial satellites in orbit. This decision would depend on the technological feasibility of such a system and its overall affordability. It would also be driven by the existential threat of nuclear proliferation in hostile countries like Iran and North Korea. For, now, participating in ground-based missile defence is still an option for Canada and many have argued in recent years that the new government should reconsider its position to help solidify NORAD relations (see, among others: Kenny, 2006; MacKenzie, 2008; and Fergusson, 2010). Prime Minister Stephen Harper pledged in 2006 that he would hold a free vote in the House of Commons after his party was elected and this has yet to happen. Given the right political circumstances, however, some believe the issue of missile defence could reappear on the political agenda in Canada. 
Beyond missile defence, Canada-United States co-operation in military space projects could also become a contentious issue depending on America's actions in space. As a partner in NORAD, Canada depends on America's ballistic missile early warning systems (BMEWS) for notification of a nuclear attack on North America. Canada will also be co-operating with the United States on space surveillance by launching the Sapphire satellite into orbit. The satellite will relay tracking information and surveillance data of Earth orbiting objects directly to the Joint Space Operations Center (JSpOC) as part of Canada's contribution to NORAD. Along with Sapphire, the Department of National Defence has funded a joint project involving the development of micro-satellites to help track foreign satellites and asteroids in higher orbits. The NEOSSat project, like Sapphire, will feed information into the United States Space Surveillance Network. Given Canada's involvement in NORAD, a decision by the United States to deploy space-based missile defence could conceivably spark public opposition to joint military space projects between the two countries.

If history is any indication, public opinion about these issues will likely be shaped by a number of actors, including politicians, academics, activists, and the media. Since Masters of Space presents several arguments against missile defence and the weaponization of space, it provides a unique opportunity to measure how future generations might respond to these arguments in the mass media. 


\section{Chapter 3: Literature Review}

Having examined the documentary and identified its dominant themes, this section now provides a theoretical framework for assessing the documentary's impact on foreign policy attitudes. Three important theories about media effects are discussed in this section, including agenda-setting, priming, and framing. A rationale is offered for why these theories apply to this particular documentary and a number of hypotheses are advanced for testing.

\section{Agenda-Setting Effects}

Since Masters of Space, like most political documentaries, aims primarily at raising awareness about a political issue, it seems reasonable to expect the film to have an agenda-setting effect on its viewers. Agenda-setting theory holds that the media is capable of shaping the public's perception about the salience of an issue by simply reporting on that issue more frequently than on others. McCombs and Shaw (1972) were the first to introduce the concept when emphasizing the mass media's role in shaping what issues voters perceived as most important during the 1968 presidential election campaign. In their study, the researchers interviewed 100 residents of Chapel Hill North Carolina and asked them to outline the key election issues as they saw them. Only respondents that were uncommitted to any particular party or candidate were selected for further analysis. When the researchers cross-referenced individual level data with data from a separate content analysis of news articles and television broadcasts, they found near perfect correlations between the level of emphasis the media placed on certain issues and the level of salience respondents attributed to those same issues. They also found that the importance voters attributed to issues did not reflect the amount of 
attention those issues received from the three political candidates. McCombs and Shaw concluded that editors, newsroom staff, and broadcasters are influential in determining what issues get placed on the political agenda during election campaigns. This gave new life to Cohen's statement that the press "may not be successful much of the time in telling people what to think, but it is stunningly successful in telling its readers what to think about" (1963: 13).

McCombs and Shaw sparked massive interest in the study of media effects and prompted many others to begin studying the phenomenon using a similar cross-sectional approach. By 1982, research on agenda-setting effects had produced mixed results and Iyengar and associates (1982) attributed the lack of consistent findings to the use of these cross-sectional designs, which they claimed failed to effectively capture the appearance and disappearance of major issues in the media over time. To address the problem, the researchers ran a series of experiments in which different groups of participants were asked to watch newscasts over a period of six days and to evaluate the relative importance of national problems both before and after the viewing. Participants in both experiments were broken up into different groups and exposed to the previous evening's news broadcasts, edited differently for each group to include significantly more reporting about a specific issue. The findings for the first experiment showed that participants whose news programs had been infused with more stories about the vulnerability of U.S. defence capabilities grew significantly more concerned about defence with each passing day. These findings were then replicated in the second experiment and also extended to the issue of pollution. These results suggested that the media, by attending to some problems more than others, could profoundly affect which problems viewers took seriously. This led Iyengar and associates to 
argue for a revival of experimentation in political communication as a more effective means of identifying and explaining agenda-setting effects.

Although, research on agenda-setting steadily progressed during the $1970 \mathrm{~s}$ and $80 \mathrm{~s}$, it would take nearly two decades before researchers investigated the cognitive processes underlying these effects (Shah et al., 2009). Iyengar (1990) was the first to develop a comprehensive theory of agenda-setting when he linked the phenomenon to a well-known memory-based model of information processing developed by Wyer and Srull (1986). These researchers had merged a number of isolated theories into a broad conceptual framework to explain how the human cognitive system operates in its natural social context. The authors described the model metaphorically as "an interrelated system of both storage and processing units" connected and monitored by "an Executor that controls the flow of information from one unit to another and transmits instructions to the various processing units" (Wyer \& Srull, 1986: 323). In brief, Wyer and Srull envisioned the human mind as a kind of manufacturing plant where new information was constantly being scooped up by the senses, encoded, organized into a number of "storage bins" in ones memory, and later called upon when required for developing judgements or decisions about a person, object, or issue in society.

Of particular interest to Iyengar was the idea of "referent bins." These bins had been originally envisioned by Wyer and Srull as "containing the knowledge one has accumulated about persons, objects, and events or prototypic ones" (1986: 329). The bins were considered permanent storage units with headers associating them with particular thing. Although Wyer and Srull never described precisely how information was ordered or stacked within a bin, Iyengar expounded on the idea and used it to describe how news media makes certain information more retrievable in memory. Iyengar argued that "those items of 
information that have been more frequently (or recently) used are stacked at the top of the referent bins and are, therefore, encountered first when individuals locate the appropriate bin" (1990: 3). Drawing on other theories pointing to "the human proclivity to simplify" the decision making process, Iyengar reasoned that extensive news coverage of an issue simply renders that issue more easily retrievable in memory when individuals are subsequently asked to judge the relative importance of that issue.

Iyengar's research on agenda-setting in the 1980 s caused another significant shift in the study of media effects toward understanding the interaction between the media and the individual's cognitive system (Shah et al., 2009). However, the extent to which his accessibility-based model of agenda-setting accurately measures the perceived importance of issues is still a matter of debate (Scheufele, 1999; Schuefele, 2000; Takeshita, 2006; Scheufele \& Tewksbury, 2007). The term 'salience' is often either equated with 'accessibility' or defined as 'perceived importance' (Takeshita, 2006). The term has become progressively more associated with accessibility-based models of agenda-setting and it is therefore best measured using latent response variables if one is measuring memory recall (Scheufele, 2000). But as Takeshita argues, the term salience was more likely conceived by McCombs and Shaw to mean 'perceived importance' because they had first associated agenda-setting effects with the 'status conferral function' of the mass media: the idea that the media bestows a certain level of prestige or importance on individuals and issues and that this, in turn, is transmitted to the audience (2006). For this reason, Takeshita claims that the concept of salience in agendasetting ought not to be equated with the concept of accessibility, but rather with the amount of importance viewers attribute to an issue.

As for the issues themselves, a number of studies have found that the media can significantly increase the importance of foreign policy issues. Iyengar and Simon (1993), for 
instance, studied the agenda-setting effects of Gulf War media coverage by plotting the average amount of monthly coverage against the percentage of Gallup poll respondents nominating that issue as most important between April 1990 and March 1991. The researchers noticed a 'bi-directional' effect in their findings. That is, the emergence of the Gulf issue in the media not only increased the perceived importance of that issue, but simultaneously drove down the importance the public attributed to economic and crime related issues, which had been far more prevalent before the war began. Soroka (2003) obtained similar results when he examined the agenda-setting effects of American and British media networks on foreign policy issues. By regressing aggregate survey scores of 'most important issue' responses on the frequency of foreign policy coverage in major newspapers, Soroka found that media content affected public attention to foreign affairs in both countries and that this rendered foreign policy issues more important in the public eye.

While these survey-based studies provide valuable insight about the agenda-setting effects of news media, they do not provide causal evidence of salience transfer at the individual level. Moreover, like most studies, they add to the literature on news-media effects, but overlook the influence of alternate media sources. Since recent studies have called for the expansion of agenda-setting research to other forms of media (Shah et al., 2009), this study examines the agenda-setting effects of a documentary. Here, as prescribed by Takeshita (2006), agenda-setting is defined as perceived importance of an issue rather than the accessibility of an issue in short term memory. The high level of importance film-maker Denis Delestrac attributes to the issue of space weaponization is expected to carry over to his audience and raise their perceived importance of it during the viewing. Moreover, in keeping with the findings from Iyengar and Simon (1993), since the documentary simultaneously portrays the nuclear threat to America as shrinking, a bi-directional effect is expected, where 
a rise in the importance of space weaponization will be accompanied by a fall in the perceived importance of nuclear proliferation. These expectations are summarized as follows:

Hypothesis 1: Participants watching the documentary will attribute a) more importance to the issue of space weaponization and b) less importance to the issue of nuclear proliferation after the viewing. 


\section{Second-Level Agenda-Setting Effects}

Early agenda-setting research (or first level agenda-setting) has been criticized in recent years for overlooking the influence that specific attributes of an issue can have on the overall perceived importance of that issue (Shah et al., 2009). Critics argue that overlooking these attributes causes one to overlook the true source of media influence: the media's tendency to emphasize certain attributes of an issue over others. McCombs and associates (2000) were the first to advance agenda-setting research to the second level by comparing the media's emphasis on characteristics of electoral candidates with the characteristics voters found most important in those candidates during the 1996 Spanish General Election. These researchers found strong correlations between the two measures, supporting claims that the media can influence what aspects of a political candidate viewers find most important.

Beyond the realm of electoral politics, Craft and Wanta (2004) found that the media can also influence which aspect of a foreign policy issue viewers find most important. When examining the media's coverage of the aftermath of the 9-11 terrorist attacks, the researchers found that the media influenced which aspects of the issue viewers considered of greatest concern to their personal well-being. In particular, they found that the public agenda was highly correlated with the media agenda on two of the three most publicized issue attributes - future terrorist attacks and the effects of terrorist attacks on the economy - but that the Israel-Palestine conflict ranked higher on the media's agenda than it did in the minds of respondents. These results showed that the personal consequences associated with terrorist attacks outweighed the effects of extensive coverage of a separate issue (Israeli-Palestinian conflict) on judgements about the salience of issues. 
These findings suggest the possibility that Masters of Space may also have a secondlevel agenda-setting effect on viewers by raising the level of importance these viewers attribute to satellite technology. The documentary opens with a segment on the many benefits average citizens derive from satellite technology, such as satellite television, ABM banking, and GPS tracking. The documentary also displays a pie chart revealing that over half of the world's satellites (commercial and military) are owned by the United States. The remainder of that segment describes how the American military is highly dependent on satellites to conduct its operations both at home and abroad. In the end, the consequence of space warfare is defined as the collateral destruction of civilian and military satellites on which people and nations depend for their well-being and security. Given the documentary's emphasis on these attributes of space weaponization, it seems fitting to advance the following hypothesis:

Hypothesis 2: Participants that watch the documentary will consider satellites more important a) to their personal way of life, b) to the American way of life, c) to the defence of North America, and d) to American military operations abroad after the viewing. 


\section{Priming Effects}

As noted in Chapter 2, the documentary Masters of Space raises doubts about President Barack Obama's commitment to banning space-based weapons by pointing out his willingness to fund counter-space research within the Department of Defense. Counter-space research is defined as "offensive measures to disrupt, deny, degrade, or destroy any adversary's space capabilities" (CBC, 2010a). This goes above and beyond the documentary's attempt to raise awareness about the risks associated with weaponizing space. In doing so, one might expect the documentary to have a 'priming effect' on how viewers feel about President Obama.

Iyengar and Kinder (1987) provided one of the earliest definitions of political priming. "By calling attention to some matters while ignoring others," they argued, "television news influences the standards by which governments, presidents, policies, and candidates for public office are judged" (Iyengar \& Kinder, 1987: 63). Simply put, viewers are more likely to judge politicians or policies based on information they obtain from news media simply because that information is more readily accessible in memory. As such, media priming is an extension of agenda-setting because it is founded on the same accessibilitybased model of information processing (Scheufele, 2000).

In building their theoretical framework, Iyengar and Kinder (1987) began by drawing on psychological research positing that the human capacity to store and process information is limited and that we organize our impressions of others around only a few central themes. The researchers also operated on a long-standing assumption that human beings prefer taking cognitive shortcuts when reasoning through a problem and rely on information that is most accessible in memory at any given time to form evaluations about others. "A person's judgement", they argued, "depends in part on what comes to mind - on considerations that 
are, for whatever reason and however briefly, accessible" (Iyengar \& Kinder, 1987: 65). Since television news is among the more important sources of information about presidential performance available to citizens, the researchers hypothesized that television news could determine the standards citizens use to evaluate presidential performance on issues by simply emphasizing these issues more than others in their broadcasts.

Iyengar and Kinder found evidence to support that hypothesis while conducting a series of experiments in the early 1980s. Participants were asked to watch a series of broadcasts over a six-day period and to evaluate both the importance of various political issues and the president's handling of those issues. Some participants were presented a broadcast with significantly more reporting on U.S. defence preparedness, while others watched broadcasts dotted with significantly more stories about inflation or unemployment. These groups were then matched against a control group to measure the effects of each broadcast on presidential evaluations. The researchers found that viewers primed with defence-oriented broadcasts were nearly three times more likely than the control group to evaluate President Carter based on his perceived performance on defence issues. Conversely, those primed with inflation and unemployment-oriented broadcasts were more likely than the control group to evaluate the President based on those issues. Additional experiments also showed that the degree to which television news broadcasts imply presidential responsibility (or ownership) of issues also determines the likelihood of issue-based evaluations.

Although Iyengar and Kinder developed their priming theory to explain the influence of news broadcasts, researchers have begun exploring its applicability to other genres of media (Roskos-Ewoldsen \& Roskos-Ewoldsen, 2009; Holbert et al., 2003; Holbrook \& Hill, 2005; Holbert \& Hanson, 2006). One study by Holbert and associates 
(2003) examined the priming effects of the prime-time television drama The West Wing on character evaluations of Presidents George H. W. Bush and Bill Clinton. The researchers found that the program produced positive perceptions of the U.S. presidency and that these positive evaluations were in turn used to evaluate the character traits of former Presidents Bush Sr. and Clinton. Holbrook and Hill (2005) found similar results when they examined the effects of crime dramas on evaluations of President George W. Bush. Using a similar experimental design, the researchers found that students watching a crime drama were more likely than those watching family dramas to rely on judgements about Bush's handling of crime to evaluate his overall performance. Another study by Holbert and Hansen (2006) examined the priming effects of Michael Moore's documentary Fabrenbeit 9-11 on viewers' "affective" assessments of President George W. Bush. Here, rather than focussing on cognitive outcomes (i.e. evaluations of performance), the researchers focussed on the documentary's increase or reduction of affective ambivalence towards President Bush in relation to one's need for closure and left-right ideological leanings. They found evidence that Republicans with a high need for closure - a preference for order and predictability were more likely to experience a greater rise in ambivalence about President Bush after viewing Moore's documentary than Democrats or Independents.

These studies recommend extending the research on presidential priming effects to alternate forms of media. Accordingly, Masters of Space provides the opportunity to test the priming effects of a political documentary because the film raises doubts about President Obama's commitment to banning space weaponization. A third hypothesis is therefore advanced as follows: 
Hypothesis 3: Participants that are primed with the documentary are more likely to judge President Barack Obama based on his perceived commitment to banning space weapons. 


\section{Framing Effects}

Since the weaponization of space has been, and may once again become, a highly contentious issue in Canadian politics, the documentary Masters of Space provides a unique opportunity to gauge whether certain messages in the media could shape attitudes and perception about the issue. To better understand how the media shapes public opinion, a brief review of the literature on framing effects is in order.

Here, a theoretical account of framing effects begins with the work of Price and Tewksbury (1997a). The Price and Tewksbury model of media effects, an associative network model, asserts the importance of taking both accessibility and applicability of information into account when measuring the influence of that information on attitudes and perceptions. In essence, the researchers expound on the work of Iyengar and Kinder (1987) to include, within a comprehensive framework, an explanation for the effects the message itself can have on viewers beyond its mere availability in memory. Price and Tewksbury base their model on the assumption that constructs, or pieces of information in memory, are linked together in the form of cognitive networks. When a particular construct (or node) within a network is brought into awareness (or activated) through outside stimulation (i.e. hearing about a concept in the media), then the activation spreads from one node to many others along various neural pathways. This means activating the construct of, say, missile defence can raise the likelihood that other related constructs such as President Bush, NORAD, and Canada-United States defence relations could be activated within the individual's mind.

Price and Tewksbury argue that news production practices and journalists' values can influence public opinion along one of two routes (2007b; see also Brewer et al., 2003). First, 
the media can have an indirect influence on public opinion by reporting on certain stories they deem more newsworthy than others. As the authors put it:

The inevitable selection of newsworthy issues and events out of the universe of possible incidents and developments can lead audiences to develop a media-induced, and perhaps distorted, view of the greater political environment (Price \& Tewksbury, 2007b).

By making certain issues more salient than others, the media also increases the likelihood that these issues will be used by individuals to make judgements about politicians and policies. These are the traditional agenda-setting and priming effects (discussed earlier) that the researchers rely on to build their theoretical framework.

An important implication of these accessibility-based effects is that a news story or coverage need not necessarily be directly related to the target of judgement (Brewer et al., 2003). That is, the particular issue covered by the media need not pertain directly to an individual or a policy for viewers to use that issue in their evaluations of him or it. In this sense, agenda-setting and priming effects are considered indirect forms of media influence because viewers typically lack awareness about the media's effects on their personal judgements.

Direct effects, on the other hand, are primarily associated with the concept of media framing. To frame, according to Entman, is "to select some aspects of a perceived reality and make them more salient in a communicating text, in such a way as to promote a particular problem definition, causal interpretation, moral evaluation, and/or treatment recommendation for the item described" (1993). The Masters of Space documentary, for example, frames a number of American military 
space assets as potential weapons that could be used by the United States to destroy foreign satellites. Missile defence, for one, is referred to as a 'Trojan horse' - an anti-satellite system in disguise - by one activist as well as 'the greatest fraud' ever perpetrated by the Department of Defence by another. While doing so, the documentary also omits information about the way the system works, its capabilities, and its limitations.

When the media frames issues in a particular light, it can impact the way viewers think about these issues (Miller and Krosnick, 2000). As such, framing effects are generally experienced during the viewing and involve both interpretation and reaction to specific stories produced by the media (Price \& Tewksbury, 1997a). Whether or not the information obtained from the story is subsequently activated for use in evaluating a target person or object depends on its applicability to the task at hand. This can otherwise be conceptualized as the activation of one node leading to the subsequent activation of many others along associated pathways. The overall process implies a conscious decision made by the viewers about the actual relevance of the information.

A number of studies in recent years have lent support to this theoretical model. In a follow up study, Price and associates (2007b) examined the effects of news frames on student attitudes towards university tuition caps. The researchers found that reading different versions of a news articles about the issue - one emphasizing conflict, one emphasizing human interest, and one emphasizing consequences - had different effects on the extent to which students opposed or supported tuition caps. Those reading the article framing state budget cuts as having positive consequences for tuition rates (lower rates) were significantly more likely than those that did not to support tuition caps. Interestingly, participants reading the articles emphasizing interest group conflict and human interests produced fewer thoughts about tuition increases. Drawing on the Price and Tewksbury 
model for theoretical support, the researchers concluded that framing issues in a particular light can induce knowledge activation and, in turn, significantly influence decision making by altering the mix of considerations brought to mind.

Drawing on the same model, Brewer and associates (2003) investigated two possible routes - priming and framing - by which the news media can affect evaluations of foreign countries. Using a similar experimental design, the researchers exposed participants to newspaper stories linking foreign nations to anti-terrorism and anti-drug trafficking. The researchers found that stories portraying Iran as a sponsor of terrorism significantly altered the impact participants' attitudes about American anti-terrorism efforts had on their evaluations of Iran. Exposure to stories framing Mexico and Columbia as American allies in the drug war also caused participants to draw a positive correlation between attitudes about the war on drugs and their attitudes towards Mexico and Columbia. This led the researchers to conclude that shaping how a mass audience judges another country can be achieved by providing the audience with "a frame that explains what issue is at stake and on which side of the issue the foreign nation stands" (Brewer et al., 2003: 506).

Although these two particular studies focus on the effects of newsprint media, a number of studies have investigated the framing effects of alternate forms of media. An earlier study by Williams and associates (1985) examined whether watching a 1983 Hollywood docudrama about astronaut John Glenn's heroics in the 1960 s enticed people to vote for Glenn as a Presidential contender that year. The experiment revealed that movie goers gave Glenn more favourable reviews as both a politician and as a person after viewing the film. Those interviewed immediately after the viewing were also more likely than the pretest group to favour Glenn as a Democratic presidential nominee and to vote for Glenn as President over incumbent Ronald Reagan. This led Williams and his colleagues to conclude 
that the film had "an apparent 'halo effect' whereby favourably perceived characteristics in one area overlap into higher evaluations in other areas" (1985: 333).

Meanwhile, Feldman and Sigelman (1985) examined the effects of the prime-time television movie The Day After on various attitudes and perceptions associated with nuclear war. Results showed, among other things, that the movie's depiction of a nuclear war between the United States and Russia caused viewers to favour cutting defence spending. Less educated viewers also became more worried about American nuclear defences than they had been prior to the viewing. Although the film had no significant effects on attitudes towards nuclear arms limitations, its depiction of life after the bomb had fallen moved viewers to believe that basic services such as food, shelter, and medical care would not be available after an attack and that their chances of survival would be very slim. Together, the results suggested that the effects of fictional television programs were equally as deserving of attention as network news, especially when deemed credible sources of information by the audience.

A similar study by Lenart and McGraw (1987) revealed that the prime-time television mini-series Amerika, depicting life in the United States ten years after a Soviet invasion, had a significant impact on political attitudes towards that country. For instance, viewers became less tolerant of communism after watching the program and more accepting of increasing America's military strength. The film also re-enforced positive stereotypes about Americans compared to Russians. The researcher attributed these finding to the film's "dominant message: namely, that Americans need to be increasingly vigilant against the Soviet threat" (Lenart \& McGraw, 1987: 710). Although these studies on entertainment media did not explicitly define the results as framing effects, they do suggest the possibility that alternate 
media sources can shape public opinion about foreign policy issues by framing them in a particular light.

The current study extends research on framing effects one step further towards the study of political documentaries. Military space relations with the United States could become a controversial issue in Canada and Masters of Space provides a unique opportunity to gauge the impact certain messages might have on public opinion. Canada may once again be confronted with an American offer to participate in missile defence. Its involvement with the United States in satellite tracking and micro-satellite programs is considered vital for preserving NORAD relations (see Fergusson, 2010). Since the documentary examines the issue of dual-use space technology and touches on America's military space program, it provides an interesting opportunity to examine how space security arguments in the media might one day affect future generations. With these possibilities in mind, the following two hypotheses are advanced:

Hypothesis 4: Participants watching the documentary will demonstrate more opposition to Canada-United States co-operation on a) tracking the satellites of other countries, b) tracking space debris, c) developing a missile defence system, and d) developing micro-satellite technology after the viewing.

Hypothesis 5: Participants watching the documentary will perceive America's space policy as being more aggressive towards other countries after the viewing. 


\section{Core Values and Beliefs}

Since Hypotheses 4 and 5 examine the formation of attitudes and perceptions towards foreign policy issues, it is equally beneficial to consider the impact certain core values and beliefs might have on the way viewers react to information in the documentary. In their seminal work on the cognitive determinants of foreign policy attitudes, Hurwitz and Peffley (1987) found that attitudes about foreign policy issues were constrained by higher levels of domain beliefs and core values. Using structural equation modelling on a random sample of Americans, the researchers found that policy preferences on more specific issues, such as military involvement and defence spending, were highly correlated with more abstract beliefs, such as belief in having strong military forces and preference for isolationism in world affairs. These beliefs were, in turn, constrained by higher and more abstract values such as partisanship and thoughts about the morality of warfare.

In a similar study, Peffley and Hurwitz (1985) found that specific foreign policy attitudes towards defence spending and relations with (Soviet) Russia were highly correlated with broader domain beliefs, such as promoting national empathy towards other countries and being understanding and flexible in international relations. These beliefs were, in turn, highly correlated with Liberal-Conservative leanings in domestic politics. These findings led the researchers to conclude that the American public, being far less knowledgeable about international affairs than foreign policy elites, rely on certain cognitive heuristics such as beliefs and values to form their opinions about complex foreign policy issues.

Jenkins-Smith and associates (2004) obtained similar results nearly two decades later when they applied the Peffley-Hurwitz model to American and British publics. Rather than test the model on more general issue positions, these researcher applied it to specific policy 
preferences concerning American missile defence and nuclear weapons postures. Using a regression model fitted with interaction terms, these researchers found that support for missile defence was highly constrained by partisanship and beliefs about international affairs. In particular, right-wing respondents and those believing countries must tend to their own interests were far more supportive of plans to erect a missile defence shield in Europe and North America. The researchers concluded that one "must not underestimate the theoretical significance of the structure and distribution of mass beliefs" and encouraged future application of the Peffley-Hurwitz model to mass publics in other countries.

Although these studies were all based on national-level data, they raise the possibility that participants in this study might form their attitudes towards Canada-United States defence relations based on partisan predispositions and existing world views. Furthermore, viewers might also respond differently to information in the documentary based on different values and beliefs. In light of these findings, ideology, beliefs about international relations, and general attitudes towards the United States will all serve as control variable and potential moderators when measuring the documentary's impact on policy preferences. 


\section{Chapter 4: Methodology}

\section{Design}

Media effects are often examined using a true experimental design. This involves randomly dividing participants into two or more groups and comparing group scores on a given measure after the treatment group is exposed to some media stimulus. If treatment group participants report significantly higher or lower attitudinal scores, then the treatment is said to be causing a rise or a fall in these attitudes respectively. In cases where true experiments are either impractical or unfeasible, researchers have been encouraged to approximate such a design by comparing treatment group scores with those of a similar, but non-equivalent, control group. This particular 'quasi-experimental' design, as coined by Campbell (Campbell, Russo 1999; 363), has been especially popular in educational research where, for instance, student grades are compared between classrooms to measure the relative effectiveness of teaching techniques. This kind of design can also produce highly reliable results if participants from both groups differ little in personal characteristics and attitudinal scores at first measurement.

A non-equivalent control group design with pre-test and post-test measures was used to measure the documentary's effects. Undergraduate students from a third-year political science course (PSCI 3107) were recruited as treatment group participants and similar students from another third year course (PSCI 3606) were recruited as non-equivalent control group participants. The treatment group class was selected because its instructor happened to be airing the documentary in her course. The control group class was selected because it happened to be scheduled at precisely the same time of day and dealt with a 
similar subject matter. To minimize the influence of class lectures and assigned readings on students' attitudinal responses, the experiment was conducted early in the term at the beginning of the second week's class.

The experiment was conducted on the morning of January $14^{\text {th }}, 2011$. With the instructor's consent, the researcher began by approaching students in the treatment classroom and inviting them to participate in the experiment. Students were informed that participation would entail completing a brief questionnaire, watching the documentary, and filling out a second questionnaire immediately after the viewing. They were also informed that their participation would have no bearing on their academic grades and that they could refuse to participate or withdraw their participation at any time during the experiment. They were then asked to read the letter of information and sign the consent form if they wished to participate. After carrying out the treatment phase of the experiment, the researcher then moved on to the control group classroom and repeated the same procedure without airing the documentary between surveys. The experiment was successfully carried out and only one student in the treatment group withdrew her participation. 


\section{Instruments}

Pre-test and post-test questionnaires were used to measure changes in attitudes and perceptions. Since control group participants were not exposed to the documentary, they were asked to fill out the same two questionnaires consecutively. The pre-test questionnaire included 29 items and the post-test questionnaire included 22. The pre-test questionnaire opened with questions about educational background and closed with standard sociodemographic variables such as age, gender, place of birth, province of origin, partisanship, and political orientation. The post-test survey opened with questions about the documentary and its perceived credibility and closed with a battery of questions probing for agreement or disagreement with various statements made in the film. Questions common to both surveys touched on the perceived salience of security issues and their attributes, defence policy preferences, attitudes towards the United States and its space policy, and various threat perceptions. The questions were mostly derived from existing surveys to ensure accuracy and some were re-worded to offer balanced response options. Attitudes and perceptions were measured using seven-point numbered Likert scales with 1 labelled the least, 7 labelled the most, and 4 labelled 'not sure'. 


\section{Participants}

A total of 80 students - 38 in the treatment group and 42 in the control group - participated in the study. To control for selection bias, and possible selection-treatment interactions, participants were asked a number of questions concerning their background characteristics. Table 1.1 below illustrates basic descriptive statistics for all participants and compares mean scores between the two groups using proportional chi square tests and student $t$-tests where applicable. Overall, most participants were between the ages of 21 and 22 years $(42.5 \%)$ and 19 and 20 years $(28.8 \%)$. Only $12 \%$ of participants were 25 years of age and over.

Proportionally, the treatment group had significantly more participants in the 21 to 22 year age range than the control group $\left(X^{2}(1, N=80)=7.020, p=.008\right)$ and the latter had significantly more participants aged 19 to 20 than the former $\left(X^{2}(1, N=80)=5.935, p=\right.$ .015). More importantly, however, the two groups did not differ in the proportion of participants aged 23 to 25 years and up. Participants were also evenly divided between males and females $(50 \%)$ and neither the treatment group nor the control group contained significantly more or less of each.

As for educational background, participants only differed significantly in the types of courses they had taken in the past. First, the vast majority of all participants $(91.3 \%)$ reported having taken a class about international affairs, while only a third (30\%) had taken a class on national defence. It appears those having taken an IR class $\left(X^{2}(1, N=80)=3.394, p=.065\right)$ or a defence class $\left(X^{2}(1, N=80)=5.051, p=.050\right)$ had been more likely to enrol in the treatment group class about causes of war than in the control group class about Canadian foreign policy. Despite differences in previous course selection, participants in the two groups did not differ significantly in the level of interest and knowledge they reported having 
in international affairs. Participants seemed overall highly interested in learning about IR ( $M$ $=6.025, S D=0.779)$ and they were quite modest about the amount of knowledge they reported possessing about the subject $(M=4.938, S D=0.817)$. Meanwhile, the $70 \%$ of political science majors in the overall sample were evenly divided between the two groups. Participants in general had completed between 1 and 5 years of university education and the average was $2.863(S D=0.882)$. Neither group had completed significantly more years than the other.

Finally, the average participant was only slightly more left of center on a 7 point ideological scale $(M=4.228, S D=1.768)$ and the two groups did not differ significantly in their average ideological leanings. As for international beliefs, participants were on average slightly more realist than internationalist, as evidenced by their more general agreement to the statement that countries in today's world need to look after themselves $(M=3.650, S D$ $=3.218$ ). The question for this variable was borrowed from the aforementioned study by Jenkins-Smith and associates (2004). 
TABLE 1.1

Comparison of background chatacteristics of treatment group and control group respondents

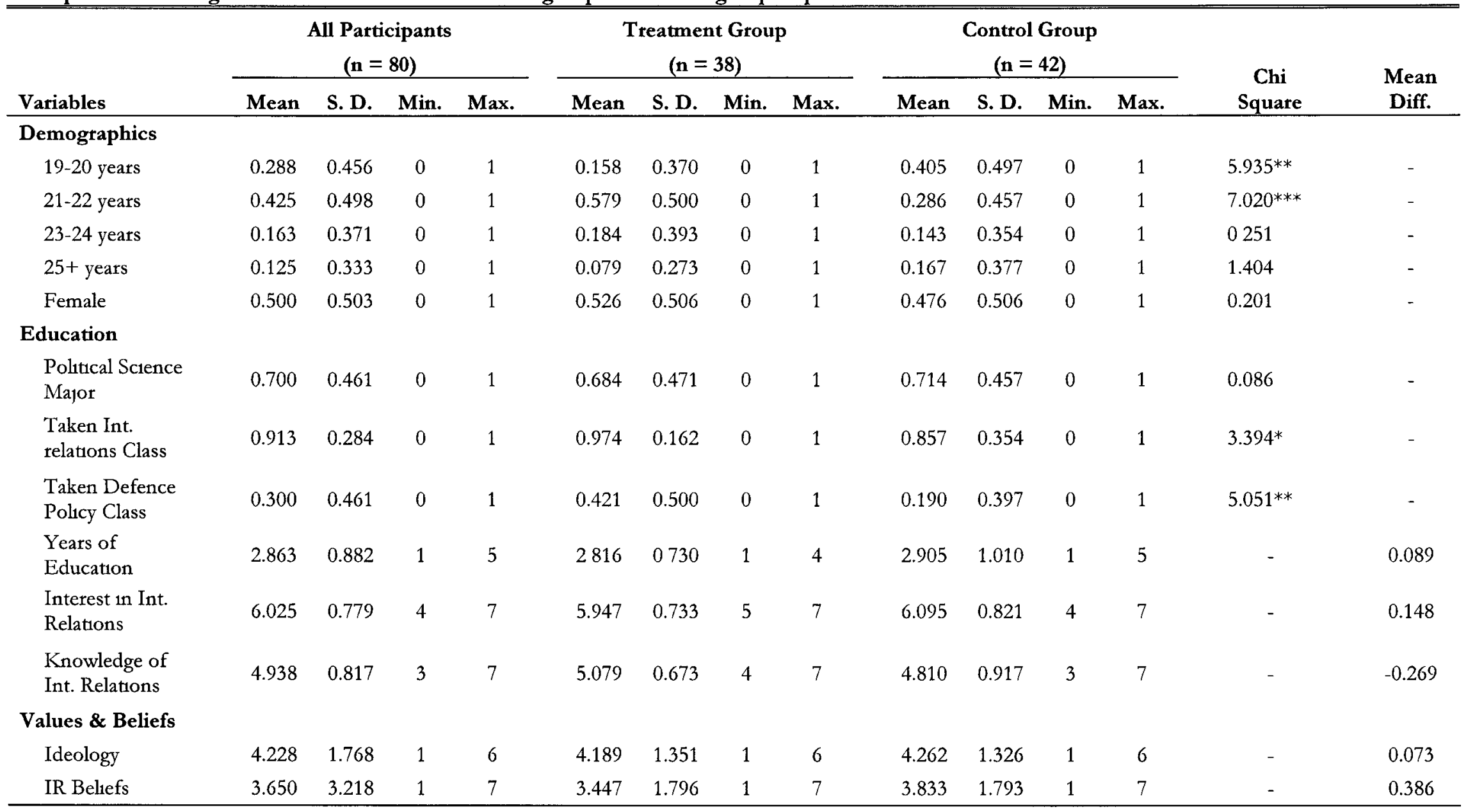

Significance Level: ${ }^{*} p<.10,{ }^{* *} p<.05,{ }^{* * *} p<.01$ 


\section{Data}

The attitudinal questions were designed to detect any agenda-setting, priming, and framing effects. Table 1.2 below provides a preliminary comparison of average scores between the two groups on dependent variables at $1^{\text {st }}$ measurement. Note that all dependent variables were measured on a seven-point Likert scale. As one might expect, the two groups did not differ significantly in their original perceptions about the salience of nuclear proliferation and space weaponization issues. Respondents were asked: "In your opinion, how important is the issue of nuclear proliferation?" On average, treatment group participants believed the issue was slightly more important than unimportant $(M=5.368, S D=1.149)$ and control group participants shared similar views $(M=5.381, S D=1.696)$. When asked "And how important is the issue of space weaponization?" immediately after, respondents in both the treatment group $(M=4.553, S D=1.465)$ and the control group $(M=4.214, S D=1.586)$ were generally more ambivalent about this issue according to their average scores. This may simply reflect the predominance of nuclear proliferation issues in the media in recent years (i.e. Iran's alleged nuclear ambitions) when compared to more sporadic reports of spacerelated security issues like anti-satellite weapons tests.

A number of second-level agenda-setting questions were also asked on the surveys to measure more specific perceptions. The main question was phrased "How important or unimportant do you feel space satellites are to:" and participants were asked to provide a specific rating between $1=$ not at all important and $7=$ very important on four different functions served by satellites. Neither group felt that satellites were significantly more or less important than the other group for fulfilling these functions. Treatment group participants $(M=4.947, S D=1.541)$ were, on average, less inclined than the control group participants 
$(M=5.310, S D=1.689)$ to believe that satellites were important to their "personal way of life." Participants also felt that satellites were slightly more important than unimportant to "the American way of life", according to a mean of 5.132 for the treatment group ( $S D=$ $1.758)$ and 5.381 for the control group $(S D=1.448)$. Average scores were similar on the importance of satellites for "the defence of North America" and for "American military operations abroad". Neither group felt that satellites were significantly more or less important to serving these four functions.

Participants were also asked priming-related questions concerning President Barack Obama and his position on space security. The SpaceBan variable measured responses to the question "In your opinion, how committed or uncommitted is President Barack Obama to banning weapons in space?" Values reported here range from $1=$ very committed to $7=$ not at all committed. Control group participants, on average, perceived the President to be significantly more committed to banning space-based weapons than treatment group participants $(t(77)=2.207, p=.030)$. No such differences were observed between the two groups on more general opinion questions about Obama (USObama) and the United States (Attitudes_US). The former asked participants "How favourable or unfavourable are your opinions about President Barack Obama?" and the latter asked "How favourable or unfavourable are your opinions about the United States?" Values ranged from 1 = very unfavourable to $7=$ very unfavourable.

Finally, participants were asked a series of questions related to framing effects. The SpacePolicy variable represents responses to the question "And in your opinion, how aggressive or non-aggressive would you say that the United States' space policy is towards other countries?" Values here range from $1=$ not aggressive at all to $7=$ very aggressive. On average, treatment group participants perceived American space policy to be significantly 
more aggressive towards other countries than control group participants $(t(78)=2.554, p=$ .013). However, the mean difference was less than a full point on the seven point scale. Values and beliefs will be taken into account when examining the documentary's effects on post-test responses to this variable.

Another set of questions measured attitudes towards Canada-United States defence co-operation on a number of potential projects related to space security. The question opened with a statement emphasizing long-standing defence relations between the two countries. Participants were asked the following question: "Canada and the United States have worked together on a number of defence projects since the end of World War II. Looking forward, to what extent would you favour or oppose Canada participating in the following projects?" Response values were reversed and ranged from $1=$ strongly favour to $7=$ strongly oppose. SatTracking measures whether respondents would favour or oppose "Developing a system to locate and track the satellites of other countries?" The following variable DebTracking measured attitudes towards "Developing a system to locate and track space debris" MissileDef measured attitudes towards "Developing a missile defence system to defend against incoming ballistic missiles" The last variable MicroSats measured attitudes towards 'Developing smaller 'micro-satellites' that can navigate towards and around other satellites." Participants from both groups, on average, were more supportive than opposed to the idea of co-operating on these projects and no significant differences in attitudes existed between the two groups. Overall, these groups only differed significantly on perceptions about Obama's commitment to banning space weapons and to perceptions about the aggressiveness of U.S. space policy towards other countries.

Turning now to pre-test and post-test differences, Table 1.3 below provides a comparison of mean scores and standard deviations on the dependent variables for all 
participants involved in the study. The mean difference between first and second measurement appear larger among the framing and agenda-setting variables than the priming variables. None, however, exceeded a one-point unit shift on average. The largest observed difference in these scores, without necessarily testing for significance, appears to be on perceived importance of the space weaponization issue (SpaceWeapons $=-.582)$ and the smallest (non-existent) difference was in attitudes towards the United States (AttitudesUS = $.000)$. Table 1.3 serves as a point of reference for interpreting the upcoming results. 


\section{TABLE 1.2}

Comparison of scores on dependent variables at 1st measurement between treatment group and control group participants

\begin{tabular}{|c|c|c|c|c|c|c|c|c|c|c|c|}
\hline \multirow[b]{2}{*}{$\begin{array}{l}\text { Dependent Variables } \\
\text { (1st Measurement) }\end{array}$} & \multirow[b]{2}{*}{$\mathbf{N}$} & \multicolumn{4}{|c|}{$\begin{array}{l}\text { Treatment Group } \\
\qquad(\mathbf{N}=\mathbf{3 8})\end{array}$} & \multirow[b]{2}{*}{$\mathbf{N}$} & \multicolumn{4}{|c|}{$\begin{array}{l}\text { Control Group } \\
(N=42)\end{array}$} & \multirow[b]{2}{*}{$\begin{array}{l}\text { Mean } \\
\text { Diff. }\end{array}$} \\
\hline & & Mean & S. D. & Min. & Max. & & Mean & S. D. & Min. & Max. & \\
\hline \multicolumn{12}{|c|}{ Agenda-Setting Variables } \\
\hline Proliferation & 38 & 5.368 & 1.149 & 3 & 7 & 42 & 5.381 & 1.696 & 1 & 7 & -.013 \\
\hline SpaceWeapons & 38 & 4.553 & 1.465 & 1 & 7 & 42 & 4.214 & 1.586 & 1 & 7 & .338 \\
\hline SatPersonal & 38 & 4.947 & 1.541 & 2 & 7 & 42 & 5.310 & 1.689 & 1 & 7 & -.362 \\
\hline Sattmercs & 38 & 5.132 & 1.758 & 1 & 7 & 42 & 5.381 & 1.448 & 1 & 7 & -.249 \\
\hline SatDefence & 38 & 5.368 & 1.403 & 2 & 7 & 42 & 5.714 & 1.255 & 1 & 7 & -.346 \\
\hline SatOperations & 38 & 5.711 & 1.346 & 2 & 7 & 42 & 5.595 & 1.822 & 1 & 7 & .115 \\
\hline \multicolumn{12}{|l|}{ Priming Variables } \\
\hline SpaceBan & 37 & 4.351 & .889 & 3 & 7 & 42 & 3.881 & .993 & 1 & 7 & $.470^{*}$ \\
\hline USObama & 38 & 3.053 & 1272 & 1 & 6 & 42 & 2.833 & 1.576 & 1 & 7 & .219 \\
\hline Att1tudesUS & 38 & 3.763 & 1532 & 1 & 7 & 42 & 3.690 & 1.600 & 1 & 7 & .073 \\
\hline \multicolumn{12}{|l|}{ Framing Variables } \\
\hline SpacePolicy & 38 & 5.026 & .915 & 4 & 7 & 42 & 4.429 & 1.151 & 1 & 7 & $.598^{*}$ \\
\hline SatTracking & 38 & 3684 & 1.844 & 1 & 6 & 42 & 3.524 & 1.518 & 1 & 7 & .160 \\
\hline DebTrackıng & 37 & 2.838 & 1.236 & 1 & 6 & 41 & 3.122 & 1.552 & 1 & 6 & -.284 \\
\hline MissileDef & 38 & 3.105 & 1.737 & 1 & 7 & 42 & 3.262 & 1.563 & 1 & 7 & -.157 \\
\hline MicroSats & 38 & 3.658 & 1.146 & 1 & 7 & 42 & 3.571 & 1.346 & 1 & 7 & .087 \\
\hline
\end{tabular}

Stgntficance: ${ }^{*} \mathrm{p}<.05$ 
TABLE 1.3

Descriptive statistics for dependent variables at $1^{\text {st }}$ and $2^{\text {nd }}$ measurement for all participants

\begin{tabular}{|c|c|c|c|c|c|c|c|c|c|c|}
\hline \multirow[b]{2}{*}{ Dependent Variables } & \multirow[b]{2}{*}{$\mathbf{N}$} & \multicolumn{4}{|c|}{$1^{\text {st }}$ Measurement } & \multicolumn{4}{|c|}{$2^{\text {nd }}$ Measurement } & \multirow{2}{*}{$\begin{array}{c}\text { Mean } \\
\text { Diff. }\end{array}$} \\
\hline & & Mean & S. D. & Min. & Max. & Mean & S. D. & Min. & Max. & \\
\hline \multicolumn{11}{|c|}{ Agenda-Setting Variables } \\
\hline Proliferation & 78 & 5423 & 1437 & 1 & 7 & 5513 & 1403 & 1 & 7 & -090 \\
\hline SpaceWeapons & 79 & 4367 & 1537 & 1 & 7 & 4949 & 1449 & 1 & 7 & -582 \\
\hline SatPersonal & 80 & 5138 & 1621 & 1 & 7 & 5375 & 1679 & 1 & 7 & 238 \\
\hline Satdmercans & 80 & 5263 & 1597 & 1 & 7 & 5450 & 1574 & 1 & 7 & -188 \\
\hline SatDefence & 80 & 5550 & 1330 & 1 & 7 & 5400 & 1308 & 1 & 7 & 150 \\
\hline SatOperations & 79 & 5709 & 1537 & 1 & 7 & 5759 & 1407 & 1 & 7 & -051 \\
\hline \multicolumn{11}{|l|}{ Priming Variables } \\
\hline SpaceBan & 78 & 4103 & 975 & 1 & 7 & 4090 & 1130 & 1 & 7 & 013 \\
\hline USObama & 79 & 2949 & 1440 & 1 & 7 & 3013 & 1523 & 1 & 7 & -063 \\
\hline AttitudesUS & 79 & 3725 & 1559 & 1 & 7 & 3725 & 1559 & 1 & 7 & 000 \\
\hline \multicolumn{11}{|l|}{ Framing Variables } \\
\hline SpacePolıcy & 79 & 4709 & 1088 & 1 & 7 & 5076 & 1238 & 1 & 7 & -367 \\
\hline SatTracking & 80 & 3600 & 1437 & 1 & 7 & 3813 & 1600 & 1 & 7 & -213 \\
\hline DebTracking & 77 & 2961 & 1400 & 1 & 6 & 2714 & 1486 & 1 & 7 & 247 \\
\hline MissileDefence & 79 & 3203 & 1644 & 1 & 7 & 3405 & 1621 & 1 & 7 & -203 \\
\hline MicroSatellites & 79 & 3608 & 1255 & 1 & 7 & 3772 & 14496 & 1 & 7 & -165 \\
\hline
\end{tabular}

Note No significance tests were performed at this stage 


\section{Models}

The basic model used to measure the documentary's first and second-level agenda-setting effects can be expressed in the following terms:

$$
Y_{2}=\beta_{0}+\beta_{1} \text { Film }+\beta_{2} \text { Lagged } \mathrm{DV}_{t 1}+e
$$

For the first hypothesis, $Y_{\mathrm{t} 2}$ represents the post-test measurements for one of two dependent variables measuring the perceived salience of the nuclear proliferation issue (NukeProliferation) and the space weaponization issue (SpaceWeaponization). For the second hypothesis, the term represents post-test measurements for one of four dependent variables measuring the importance of satellites to one's personal way of life (SatPersonal), to the American way of life (SatAmericans), to the defence of North America (SatDefence), and to American military operations abroad (SatOperations). The Treatment term represents a dummy-coded variable indicating whether or not the individual was exposed to the documentary during the experiment. Its values are $1=$ watched the documentary and $0=$ did not watch it. The term $\beta_{2}$ Lagged $D V_{t 1}$ represents the pre-test measurement of the given dependent variable in the equation. Adding the lagged DV to the model allows for the assessment of exposure effects independent of pre-existing attitudinal differences. The overall approach has commonly been used in the literature on media effects (see Feldman and Sigelman, 1985; Iyengar and Kinder, 1987; Lenart and McGraw, 1989; and Bennett, 2009 for examples).

The first hypothesis was tested by computing the model for each dependent variable and comparing results. If the Film coefficient is significant when controlling for the lagged 
DV, then the documentary can be said to influence perceptions about the salience of the issues. Furthermore, the $R-S q u a r e$ value will provided a basis for comparing the overall amount of variance explained in post-test measures of issue salience when controlling for the treatment's effects and pre-test measures of the dependent variables. If the treatment's effects were greater on the perceived salience of space weaponization compared to nuclear proliferation, then the null hypothesis could be rejected. The second hypothesis was tested in a similar way by computing the model four times for each of the dependent variables. The four models were then compared to measure perceptions about the relative importance of satellites for various personal and military functions.

Iyengar and Kinder's approach (1987) was used to test the documentary's ability to prime attitudes towards President Barack Obama (Hypothesis 3). The model can be summarized as follows:

(Step 1)

$$
\text { zUSObama }_{\mathrm{t} 2}=\beta_{1} \operatorname{spaceBan}_{\mathrm{t} 2}+\mathrm{e}
$$

(Step 2)

$$
\begin{aligned}
\text { zUSObama }_{\mathrm{t} 2} & =\beta_{1} \mathrm{zSpaceBan}_{\mathrm{t} 2}+\beta_{2} z \text { Film } \\
& +\beta_{3} \mathrm{zUSObama}_{n}+e
\end{aligned}
$$

(Step 3)

$$
\begin{aligned}
\operatorname{zUSObama}_{t 2} & =\beta_{1} \text { SPaceBan }_{\mathrm{t} 2}+\beta_{2} \text { Film } \\
& +\beta_{3} \mathrm{zUSObama}_{t 1} \\
& +\beta_{4}\left(\mathrm{zFilm}_{\mathrm{U}} \mathrm{zSpaceBan}_{\mathrm{t} 2}\right)+e
\end{aligned}
$$

Here, zUSObama ${ }_{2}$ represents one of two post-test dependent variables measuring general attitudes towards President Barack Obama (zUSObama ${ }_{\mathrm{t} 2}$ ). zSpaceBan $\mathrm{zS}_{\mathrm{t} 2}$ represents 
the extent to which participants believed President Obama was committed or uncommitted to banning weapons in space. The $z$ Film $x z \operatorname{SpaceBan}_{\mathrm{t} 2}$ term represents the interaction effect between watching the documentary and adopting the position that President Obama is less committed to banning space-based weapons. The letter $\mathrm{z}$ preceding each coefficient indicates that covariates in the model are standardized before they are entered into the equation. This procedure is recommended when testing for moderators in SPSS because the program otherwise standardizes the product of the interaction $\left(Z_{X \times Z}\right)$ rather than first standardizing each covariate and then computing the product of their interaction $\left(Z_{x} \times Z_{Z}\right)$. This can hinder one's ability to detect any real increase in the interaction term's predictive contribution to the model compared to the individual contributions of each covariate (Friedrich, 1982). Standardizing the variables also centers their distributions and reduces the occurrence of multicollinearity between the covariates (see Tabachnik and Fidell, 2004; Aguinis, 2004). The unstandardized coefficients produced are therefore interpretable as beta scores: desirable here for measuring the documentary's relative impact on predicting the outcome compared to the impact of perceptions about Obama's position on space security at Step 2.

The model, then, measures whether watching the documentary provides viewers with the necessary information about President Obama's approach to space security on which to form either favourable or unfavourable attitudes towards the President. This approach is adapted from Iyengar's work (1987) to measure indirect priming effects. That is, the model assumes that accessibility to information alone is enough for that information to be used in subsequent evaluations without consciously thinking about its use. The analysis is performed in three steps to compare changes in the amount of variance the model predicts in the dependent variables prior to and after taking the interaction term into account. If the 
interaction term is significant, and its addition significantly improves the model's predictive ability, then the documentary will be deemed to have a priming effect on its viewers.

Finally, Hypotheses 4 and 5 concerning framing effects were tested using a similar design while also controlling for values, belief, general attitudes towards the United States, and their interaction effects with the treatment. Borrowing the methodological approach of Price and associates (1997b), the model can be summarized as follows:

(Step 1)

$$
\begin{aligned}
z Y_{t 2}= & \beta_{1} z \text { Ideology }+\beta_{2} z I R \_B e l i e f s \\
& +\beta_{3} z \text { Attitudes_US } \\
t 1 & +e
\end{aligned}
$$

(Step 2)

$$
\begin{aligned}
z Y_{\imath 2}= & \beta_{1} z \text { Ideology }+\beta_{2} z I R \_B e l i e f s \\
& +\beta_{3} z \text { Attitudes_US }{ }_{t 1}+\beta_{4} z \text { Film }+\beta_{5} \text { Lagged DV } t \\
& +e
\end{aligned}
$$

(Step 3)

$$
\begin{aligned}
& z Y_{t 2}= \beta_{1} z \text { Ideology }+\beta_{2} z I R \_B e l i e f s \\
&+\beta_{3} z \text { Attitudes_US }{ }_{t 1}+\beta_{4} z \text { Film }+\beta_{5} \text { Lagged DV }_{n} \\
&+\beta_{6}(\text { Film x zIdeology })+\beta_{7}(\text { Film x zIR_Beliefs }) \\
&+\beta_{8}(\text { Film } x \text { zAttitudes_US } \\
& n
\end{aligned}
$$

For Hypothesis 4, $z Y_{i 2}$ represented one of four dependent variables measuring attitudes towards Canada-United States co-operation on different space security-related projects. Co-operation between the two countries was first framed as a normal long-standing tradition on the survey. The question was phrased: "Canada and the United States have worked together on a number of defence projects since the end of World War II. Looking 
forward, to what extent would you favour or oppose Canada participating in the following projects?" Here, the objective was to measure whether the documentary's framing of space security issues could significantly convince participants to oppose Canadian co-operation in developing a system to locate and track foreign satellites (zSatTracking), a system to locate and track space debris (zDebTrack), a missile defence system to defend against incoming ballistic missiles (zMissileDef), and smaller micro-satellites that can navigate towards and around larger satellites (zMicroSats). A different model was calculated for each dependent variable to compare the influence of competing frames on the issue while taking the control variables into account.

The same hierarchical model is then used to test Hypothesis 5. $\mathrm{z} Y_{2}$ represents posttest measures of the dependent variable zSpacePolicy measuring the extent to which participants perceived American space policy to be aggressive towards other countries. Since studies have shown that members of the mass public also rely on left-right ideological values ( $\left.\beta_{1} z I d e o l o g y\right)$, internationalist beliefs ( $\left.\beta_{2} z I R \_B e l i e f s\right)$, and general attitudes towards the United States $\left(\beta_{3} z\right.$ Attitudes_US $\left.{ }_{t 1}\right)$ as cognitive heuristics to help them form attitudes towards foreign policy issues, models testing Hypotheses 4 and 5 controlled for these factors at every step, as well as for any interaction effects between the treatment and the aforementioned control variables. 


\section{Chapter 5: Results}

\section{First and Second-Level Agenda-Setting Effects (Hypotheses 1 and 2)}

Table 2 illustrates the standardized coefficients from six regressions models testing both first and second-level agenda-setting effects. Beginning first with Model 1.1, a beta value of .41 indicates that viewing the documentary caused a significant increase in the perceived importance of space weaponization among viewers $(\beta=.41, t(78)=5.29, p<.001)$. When controlling for lagged scores on the dependent variable, exposure to the documentary appears to accounts for $56 \%$ of the variance in perceived importance $\left(R^{2}=.56, F(78)=\right.$ $48.19, p<.001)$. As hypothesized, the documentary appears to have an agenda-setting impact on its viewers.

Interestingly, similar, albeit weaker, results are obtained when testing Hypothesis 2. Model 1.2 lists the findings from a similar regression based on a slightly reduced sample of 78 participants. Contrary to expectations, watching the documentary significantly increased the amount of importance viewers attributed to the issue of nuclear proliferation $\beta=.28$, $t(77)=3.67, p<.001)$. Taking exposure into account helps predict $58 \%$ of the variance in the outcome $\left(\mathrm{R}^{2}=.58, F(77)=51.52, p<.001\right)$. This is somewhat surprising given the messages by some activists in the film that the threat of nuclear missiles is diminishing. To be sure, exposure to the documentary has a far greater impact on perceptions of space weaponization than it does on perceptions of nuclear proliferation. The documentary contributes twice as much to predicting the former than it does to predicting the latter. Yet given the positive direction of the relationship between exposure and issue salience in Model 1.2 , the results contradict Hypothesis $1 \mathrm{~b}$. 
Models 2.1 to 2.4 test for any second-level agenda-setting effects produced by the documentary. Here, all 80 participants are included in the analyses except for one in Model 2.4. As expected, Model 2.1 first reveals that watching the documentary significantly increased the perceived level of importance of satellites to one's personal way of life $(\beta=.30$, $t(79)=3.54, p=.001)$. Taking exposure into account while controlling for lagged scores helps predict $47 \%$ of the variance in issue salience $\left(R^{2}=.47, F(79)=34.65, p<.001\right)$. Similar results are obtained at Model 2.2. When asked to consider the importance of satellites to Americans and their way of life, watching the documentary significantly increases the level of importance viewers attribute to this purpose $(\beta=.18, t(79)=2.07, p=.042)$. The documentary's effects are somewhat weaker here, however, suggesting viewers are more inclined to associate what they see with their own personal conditions. Taking exposure into account predicts $44 \%$ of the variance in attribute salience: $3 \%$ less than the previous model. Meanwhile, Models 2.3 and 2.4 reveal no significant effects from exposure. Together, these findings support Hypotheses $1 \mathrm{a}$ and $1 \mathrm{~b}$ as well as $2 \mathrm{a}$ and $2 \mathrm{~b}$. They provide evidence that $\mathrm{a}$ documentary can indeed have both first and second-level agenda-setting effects on viewers. 
Table 2

Regressions predicting the perceived importance of security issues and issue attributes (Hypotheses 1 and 2)

\begin{tabular}{|c|c|c|c|c|c|c|}
\hline & \multicolumn{2}{|c|}{ Perceived importance of: } & \multicolumn{4}{|c|}{ Perceived importance of satellites for: } \\
\hline & $\begin{array}{c}\text { Space } \\
\text { Weaponization } \\
\text { (Model 1.1) } \\
\end{array}$ & $\begin{array}{c}\text { Nuclear } \\
\text { Proliferation } \\
\text { (Model 1.2) } \\
\end{array}$ & $\begin{array}{c}\text { One's } \\
\text { personal } \\
\text { way of life } \\
\text { (Model 2.1) } \\
\end{array}$ & $\begin{array}{c}\text { The } \\
\text { American } \\
\text { way of life } \\
\text { (Model 2.2) }\end{array}$ & $\begin{array}{c}\text { Defending } \\
\text { of North } \\
\text { America } \\
\text { (Model 2.3) }\end{array}$ & $\begin{array}{c}\text { Military } \\
\text { operations } \\
\text { abroad } \\
\text { (Model 2.4) }\end{array}$ \\
\hline \multicolumn{7}{|l|}{ Variables } \\
\hline Film & $.41^{* *}$ & $.28^{* *}$ & $30^{*}$ & $.18^{*}$ & .08 & -.02 \\
\hline \multicolumn{7}{|l|}{ Model Fit } \\
\hline $\mathrm{R}^{2}$ & $.56^{* *}$ & $.58^{* *}$ & $.47^{* *}$ & $.44^{* *}$ & $.61 * *$ & $.43^{* *}$ \\
\hline Adj. $R^{2}$ & $.55^{* *}$ & $.57^{* *}$ & $.46^{* *}$ & $.42^{* *}$ & $.60^{* *}$ & $.41^{* *}$ \\
\hline$N=$ & 79 & 78 & 80 & 80 & 80 & 79 \\
\hline
\end{tabular}

Note: Entries are standardized coefficients from OLS regression. The dependent variables (DVs) were scored $1=$ not important at all to

$7=$ very important, with $4=$ not sure.

${ }^{*} p<.01,{ }^{* *} p<.001$. 


\section{Priming Effects (Hypothesis 3)}

Turning now to priming effects, it was hypothesized at the outset that viewers were more likely than non-viewers to form their attitudes about President Barack Obama based on his perceived level of commitment to banning weapons in space. That is, by mentioning the President's decision to fund counter-space research programs, it was hypothesized that the documentary would make viewers question Obama's commitment to banning space-based weapons and increase the accessibility of this information for later use in forming unfavourable attitudes towards the President.

Table 3 below presents the unstandardized regression coefficients from a hierarchical regression predicting favourable opinions about the President. This dependent variable had values ranging from $1=$ very unfavourable to $7=$ very favourable, with $4=$ not sure. To reiterate, all values, including the DV, were standardized prior to being entered into the equation to avoid having SPSS standardize the interaction term after their product was computed. The coefficients can therefore be interpreted as betas and provide a common metric for comparing the documentary's effects with the effects of other variables in the model.

At Step 1, including only the SpaceBan 2 variable in the model helps one predict $18 \%$ of the variance in attitudes towards Obama $\left(R^{2}=.18, F(78)=16.40, p<.001\right)$. That is, participants were significantly more likely to have favourable opinions of Obama if they believed the President was committed to banning weapons in space $(b=.42, t(78)=4.05, p$ $<.001)$. The relationship between these variables weakens considerably at Step 2, however, when the experimental conditions are added to the model. SpaceBan2 nonetheless retains its significance as a contributor to the model $(b=.10, t(78)=2.42, p=.018)$ while the 
documentary, by comparison, has no significant impact on attitudes towards Obama $(b=$ $.01, t(78)=-0.65, p=.792)$. The model's predictive ability does increase significantly by $72 \%$ $\left(\Delta R^{2}=.72, F(2,75)=212.42, p<.001\right)$, but this can be attributed to controlling for lagged scores on the DV. Finally, Step 3 reveals no significant interaction effect between the two main IVs. Viewing the documentary does not moderate the relationship between perceptions about Obama's commitment to banning space weapons and general attitudes towards Obama. Adding the interaction term to the model only increases its predictive ability by less than $1 \%\left(\Delta R^{2}=.003, F(1,74)=163.22, p<.115\right)$ : an insignificant change in $R^{2}$. The documentary therefore had no significant priming effects on participants during the experiment. Rather, the lack of findings suggests that participants watching the film might simply have overlooked the information it conveyed about President Obama or discarded it as unnecessary for their evaluative purposes. 
TABLE 3

Regression predicting attitudes about President Obama based on his perceived commitment to banning weapons in space (Hypothesis 3 )

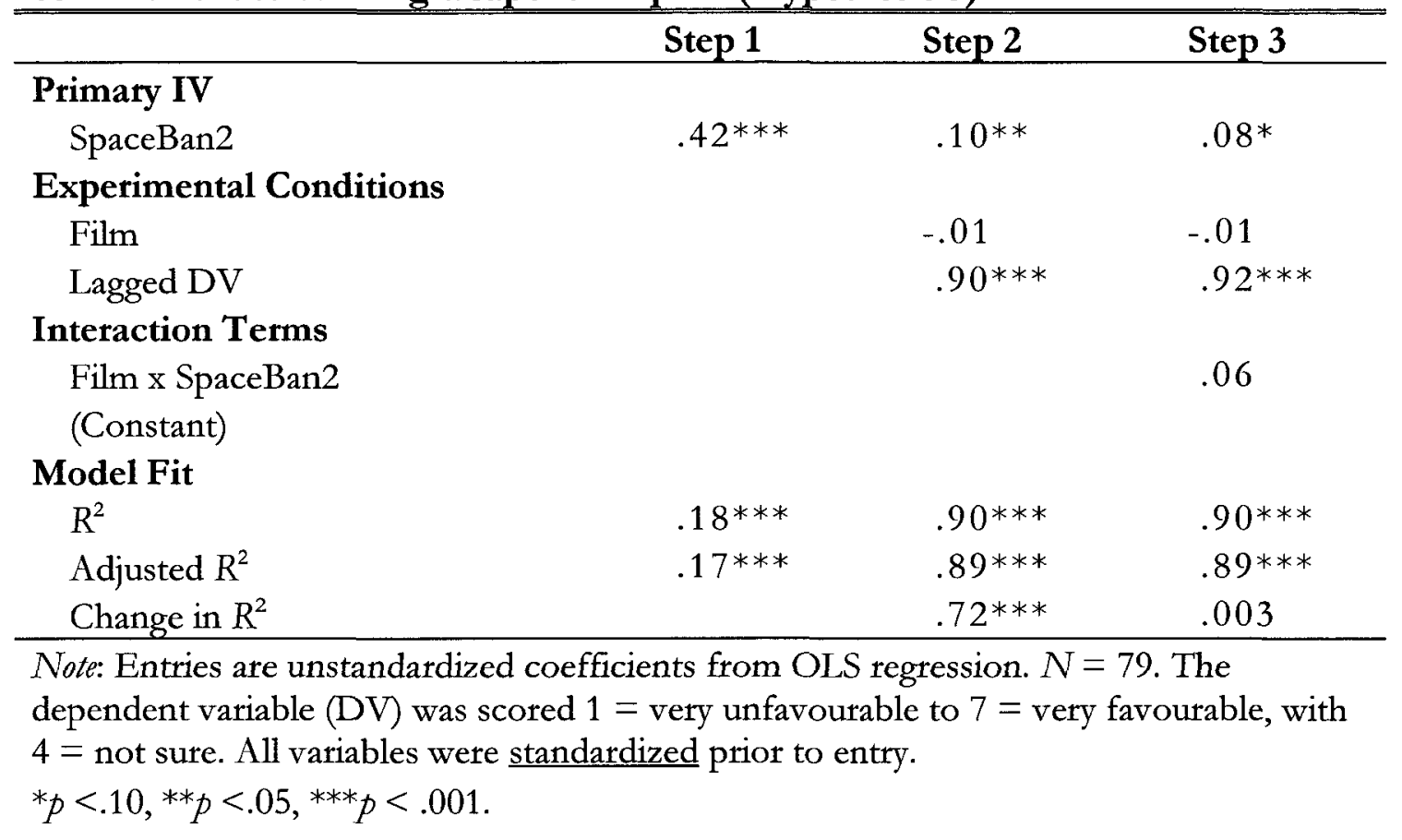




\section{Framing Effects (Hypotheses 4 and 5)}

Tables 4.1 to 4.4 below present the findings from four hierarchical OLS regressions each predicting different defence policy preferences for Canada. Results from the first regression, listed in Table 4.1, compare the documentary's impact on attitudes towards participating in missile defence along with other cognitive heuristics known to constrain foreign policy attitudes. The analysis is based on a sample of 78 participants. At Step 1, when traditional heuristics are included, ideological leanings significantly predict whether or not participants opposed missile defence participation $(b=-.34, t(77)=-3.01, p=.004)$. The negative value in front of the coefficient (in this case a beta) means that participants on the left are more likely to oppose such a policy. The model at Step 1 explains $19 \%$ of the variance in these policy preferences $\left(R^{2}=.19, F(77)=5.73, p=.001\right)$ and it is significantly more useful at predicting the outcome than relying on mean scores alone.

This changes when the experimental conditions are added to the model at Step 2. Ideology, along with other cognitive heuristics, are crowded out of the model and viewing the documentary becomes the only significant predictor of policy preferences $(b=.21, t(77)$ $=2.64, p=.010$ ) when controlling for the lagged DV. Participants viewing the documentary were significantly more likely than non-viewers to oppose Canadian participation in the development of a missile defence shield. Adding the experimental conditions also significantly improves the model's predictive ability by $36 \%\left(\Delta R^{2}=.36, F(2,72)=28.05, p<\right.$ $.001)$.

At Step 3, adding interaction terms does not significantly improve the model's overall predictive value $\left(\Delta R^{2}=.03, F(3,69)=1.32, p=.276\right)$. The model only explains an additional $3 \%$ of the variance in policy preferences about missile defence. This despite a near 
significant interaction between viewing the film and being left wing $(b=-.17, t(77)=-1.76, p$ $=.083)$. Yet the interaction term is a weaker predictor of these policy preferences than the documentary alone $(b=.21, t(77)=2.66, p=.010)$. These findings support the main hypothesis that watching the documentary causes viewers to oppose Canada's participation in missile defence more so than ideological leanings, internationalist beliefs, and prior attitudes towards the United States. Moreover, the film does not significantly impact viewers in different ways depending on their values, beliefs, and attitudes.

Table 4.2 lists the findings from a similar regression using attitudes towards developing a foreign satellite tracking system as the dependent variable. Here, the analysis is based on a sample of 79 participants. At Step 1, both ideology and attitudes towards the United States are important predictors of policy preferences. Participants with left-wing leanings $(b=-.33, t(78)=-3.03, p=.003)$ and participants with less favourable attitudes towards the United States $(b=-.26, t(78)=-2.41, p=.018)$ were more likely to oppose Canada's participation in the development of a system to locate and track foreign satellites. Beliefs about international relations, meanwhile, did not appear to contribute significantly to the model. When taking these three variables into account, the model predicts $23 \%$ of the variance in these policy preferences $\left(R^{2}=.23, F(78)=7.33, p<.001\right)$.

At Step 2, however, viewing the documentary is found to have no significant effect on these particular policy preferences $(b=.06, t(78)=0.71, p=.482)$ and adding it (along with the lagged DV) to the model renders ideological leanings and attitudes about the United States insignificant predictors. Moreover, at Step 3, there are no significant interaction terms predicting policy preferences. Although the model improves significantly at Steps 2 and 3, the additional variance it predicts in the outcome is mainly attributable to the inclusion of the lagged DV. Viewers therefore did not likely rely on information from the documentary 
to form their attitudes towards Canadian involvement in foreign satellite tracking with the United States.

These results change dramatically when the same question used as the dependent variable is re-worded to emphasize tracking of 'space debris' rather than 'foreign satellites'. Table 4.3 presents the findings from a similar regression based on a sample of 77 participants. At Step 1, none of the cognitive heuristics significantly predict policy preferences and the overall model is insignificant when including only these three variables $\left(R^{2}=.03, F(76)=0.66, p=.579\right)$. Adding the experimental condition at Step 2 drastically improves the model's predictive ability by $62 \%\left(\Delta R^{2}=.62, F(2,71)=61.95, p<.001\right)$ and allows one to predict $64.5 \%$ of the variance in these policy preferences. The film variable is the only significant predictor of the outcome $(b=-.33, t(76)=-4.47, p<.001)$, notwithstanding the lagged DV. Here, the negative sign in front of the coefficient means that members of the control group were significantly more likely to oppose Canadian participation in the joint development of a system to locate and track space debris.

Conversely, this also means viewers were significantly more likely to support such a policy after watching the film. The model's predictive ability did not significantly improve when interaction effects were taken into account at Step $3\left(\Delta R^{2}=.002, F(3,68)=.14, p=.934\right)$ and viewing the documentary remained the only significant predictor in the model. These findings suggest that participants relied on information in the documentary to evaluate the prospects of Canada-United States co-operation on space debris tracking. These effects appeared to be greater than, and independent of, ideological leaning, IR beliefs, and existing attitudes towards the United States.

Finally, results from a fourth regression model show that the documentary had little to no impact on policy attitudes towards participation in micro-satellite development. Table 
4.4 presents the findings based on a sample of 78 participants. At Step 1, Ideology is the only significant predictor of policy preferences. Left-leaning participants $(b=-.32, t(77)=-2.86, p$ $=.006$ ) were more likely to oppose participation and the model explains $16 \%$ of the variance in policy preferences $\left(R^{2}=.16, F(76)=14.24, p=.006\right)$. When adding the experimental conditions at Step 2, viewing the documentary is not found to contribute significantly to the model $(b=-.01, t(77)=-0.07, p=.946)$. It's addition does, however, cause both ideology $(b$ $=-.19, t(77)=-2.14, p=.036)$ and IR beliefs $(b=.24, t(77)=2.67, p=.009)$ to share the explained variance in policy preference. The model's efficiency improves significantly $\left(\Delta R^{2}=\right.$ $.34, F(2,72)=24.51, p<.001)$ due primarily to the inclusion of the lagged DV. A significant interaction is detected between the documentary's effects and internationalist beliefs at Step $3(b=.20, t(76)=2.21, p<.05)$. However, the interaction term is a weaker predictor than IR beliefs alone and ideology alone and its addition to the model does not significantly improve the its predictive ability, increasing it only marginally by $4 \%\left(\Delta R^{2}=.04, F(3,69)=2.1, p=\right.$ .108). The documentary did not appear to cause viewers to oppose Canada's participation in micro-satellite development with the United States. Rather, when asked to evaluate the prospects, participants in general were more likely to rely on ideology and IR beliefs to form their policy preferences. 


\section{TABLE 4.1}

Regression predicting opposition to Canadian participation in the development of a missile defence shield (Hypothesis 4a)

\begin{tabular}{llll}
\hline \hline & Step 1 & Step 2 & Step 3 \\
\hline Values and Beliefs & & & \\
$\quad$ Ideology & $-.34^{* *}$ & -.14 & $-.17^{\dagger}$ \\
$\quad$ Internationalism & -.02 & -.01 & .03 \\
$\quad$ Anti-Americanism & -.16 & -.01 & .03 \\
Experimental Conditions & & & \\
$\quad$ Film & & $.21^{*}$ & $.21^{*}$ \\
$\quad$ Lagged DV & $.65^{* * *}$ & $.68^{* * *}$ \\
Interaction Terms & & & \\
$\quad$ Film x Ideology & & & $-.17^{\dagger}$ \\
$\quad$ Film x Internationalism & & & .12 \\
$\quad$ Film x Anti-Americanism & .01 & .01 & .05 \\
$\quad$ Constant) & & & .00 \\
Model Fit & $.19^{* *}$ & $.54^{* * *}$ & $.57^{* * *}$ \\
$\quad R^{2}$ & $.16^{* *}$ & $.51^{* * *}$ & $.52^{* * *}$ \\
$\quad$ Adjusted $R^{2}$ & & $.36^{* * *}$ & .03 \\
\hline Change in $R^{2}$ & & & \\
\hline
\end{tabular}

Note: Entries are unstandardized coefficients from OLS regression. $N=78$. The dependent variable (DV) was scored $1=$ strongly favour to $7=$ strongly oppose with $4=$ not sure. All variables were standardized prior to entry.

${ }^{\dagger} p<.10,{ }^{*} p<.05,{ }^{* *} p<.01,{ }^{* * *} p<.001$. 
TABLE 4.2

Regression predicting opposition to Canadian participation in the development of a foreign satellite tracking system (Hypothesis 4b)

\begin{tabular}{|c|c|c|c|}
\hline & Step 1 & Step 2 & Step 3 \\
\hline \multicolumn{4}{|l|}{ Values and Beliefs } \\
\hline Ideology & $-.33 * *$ & -.15 & -.16 \\
\hline Internationalism & .04 & .03 & .05 \\
\hline Anti-Americanism & $-.26 *$ & -.14 & $-.17^{\dagger}$ \\
\hline \multicolumn{4}{|l|}{ Experimental Conditions } \\
\hline Film & & .06 & .06 \\
\hline Lagged DV & & $.57 * * *$ & $.54 * * *$ \\
\hline \multicolumn{4}{|l|}{ Interaction Terms } \\
\hline Film x Ideology & & & -.01 \\
\hline Film x Internationalism & & & .11 \\
\hline Film $x$ Anti-Americanism & & & -.08 \\
\hline (Constant) & .03 & .01 & .00 \\
\hline \multicolumn{4}{|l|}{ Model Fit } \\
\hline $\mathrm{R}^{2}$ & $.23 * * *$ & $.49 * * *$ & $.51 * * *$ \\
\hline Adjusted $R^{2}$ & $.20 * * *$ & $.46 * * *$ & $.45^{* * *}$ \\
\hline Change in $R^{2}$ & & $.27 * * *$ & .01 \\
\hline
\end{tabular}

Note: Entries are unstandardized coefficients from OLS regression. $N=78$. The dependent variable (DV) was scored $1=$ strongly favour to $7=$ strongly oppose with $4=$ not sure. All variables were standardized prior to entry.

${ }^{\dagger} p<.10,{ }^{*} p<.05,{ }^{* *} p<.01,{ }^{* * *} p<.001$. 
TABLE 4.3

Regression predicting opposition to Canadian participation in the development of a space debris tracking system (Hypothesis 4c)

\begin{tabular}{|c|c|c|c|}
\hline & Step 1 & Step 2 & Step 3 \\
\hline \multicolumn{4}{|l|}{ Values and Beliefs } \\
\hline Ideology & -.13 & -.03 & -.03 \\
\hline Internationalism & .08 & .08 & .08 \\
\hline Anti-Americanism & -.08 & .00 & -.01 \\
\hline \multicolumn{4}{|l|}{ Experimental Conditions } \\
\hline Film & & $-.33 *$ & $-.33^{*}$ \\
\hline Lagged DV & & $.71 *$ & $.70^{*}$ \\
\hline \multicolumn{4}{|l|}{ Interaction Terms } \\
\hline Film x Ideology & & & .02 \\
\hline Film $\mathrm{x}$ Internationalism & & & .04 \\
\hline Film $x$ Anti-Americanism & & & -.05 \\
\hline$($ Constant $)$ & -.01 & .01 & .00 \\
\hline \multicolumn{4}{|l|}{ Model Fit } \\
\hline$R^{2}$ & .03 & $.65^{*}$ & $.65^{*}$ \\
\hline Adjusted $R^{2}$ & -.01 & $.62 *$ & $.61 *$ \\
\hline Change in $\mathrm{R}^{2}$ & & $.62 *$ & .00 \\
\hline \multicolumn{4}{|c|}{$\begin{array}{l}\text { Note: Entries are unstandardized coefficients from OLS regression. } N=77 \text {. The } \\
\text { dependent variable (DV) was scored } 1=\text { strongly favour to } 7=\text { strongly oppose } \\
\text { with } 4=\text { not sure. All variables were standardized prior to entry. } \\
{ }^{*} p<.001 \text {. }\end{array}$} \\
\hline
\end{tabular}


TABLE 4.4

Regression predicting opposition to Canadian participation in the development of micro-satellite technology (Hypothesis 4d)

\begin{tabular}{llll}
\hline & Step 1 & Step 2 & Step 3 \\
\hline Values and Beliefs & & & \\
$\quad$ Ideology & $-.32^{* *}$ & $-.19^{*}$ & $-.23^{*}$ \\
$\quad$ Internationalism & .18 & $.24^{* *}$ & $.27^{* *}$ \\
$\quad$ Anti-Americanism & -.17 & -.07 & -.08 \\
Experimental Conditions & & & \\
$\quad$ Film & & -.01 & -.00 \\
$\quad$ Lagged DV & & $.62^{* * *}$ & $.58^{* * *}$ \\
Interaction Terms & & & -.12 \\
$\quad$ Film x Ideology & & & $.20 *$ \\
Film x Internationalism & .03 & .01 & -.10 \\
Film x Anti-Americanism & & & -.00 \\
$\quad$ Constant) & $.16^{* *}$ & $.50^{* * *}$ & .54 \\
Model Fit & .12 & $.46^{* * *}$ & .49 \\
$R^{2}$ & & $.34^{* * *}$ & .04 \\
$\quad$ Adjusted $R^{2}$ & & & \\
$\quad$ Change in $R^{2}$ & & & \\
\hline
\end{tabular}

Note: Entries are unstandardized coefficients from OLS regression. $N=78$. The dependent variable (DV) was scored $1=$ strongly favour to $7=$ strongly oppose with $4=$ not sure. All variables were standardized prior to entry.

${ }^{*} p<.05,{ }^{* *} p<.01,{ }^{* * *} p<.001$. 
Moving now to the effects of aggression framing, Table 5 below presents the findings from a final regression predicting the documentary's impact on the perceived aggressiveness of America's space policy towards other countries. The analysis is based on a sample of 78 participants and possible scores on the dependent variable range from $1=$ not at all aggressive to $7=$ very aggressive. When the cognitive heuristic variables are first included in the model at Step 1, only ideology is a significant predictor of perceived aggression scores $(b=-.35, t(77)=-2.94, p=.004)$. The negative coefficient means that leftleaning participants were significantly more likely to respond at the outset that American space policy is aggressive towards other countries. Including the three variables only explains $11 \%$ of the variance in perceived aggression $\left(R^{2}=.11, F(77)=3.01, p=.036\right)$.

At Step 2, when the experimental conditions are added to the equation, the model is able to predict an additional $43 \%$ of the variance in the outcome, a highly significant increase in predictive power $\left(\Delta R^{2}=.43, F(2,72)=34.01, p<.001\right)$. Ideology remains an important predictor $(b=-.33, t(77)=-3.73, p<.001)$, but exposure to the documentary is much stronger overall $(b=-.50, t(77)=5.98, p<.001)$, accounting for approximately $35 \%$ more of the variance in the dependent variable (when controlling for lagged DV scores). No interaction terms significantly predict the outcome when added to the model at Step 3 and their inclusion does not increase the model's predictive ability significantly at only $2 \%$ $\left(\Delta R^{2}=.02, F(3,69)=1.23, p=.304\right)$. When these terms are added, both ideology and exposure remain the only significant predictors in the model. It appears that watching the documentary increased the perception among viewers that the United States was pursuing an aggressive space policy towards other countries. The documentary had a greater overall impact on these perceptions than did other cognitive heuristics, such as having left-wing political leanings. The documentary also appeared to influence these perceptions 
independent of any moderating effects. That is, the documentary did not have a greater impact on left or right leaning participants, or on internationalists or more anti-American participants. 


\section{TABLE 5}

Regression predicting perceived aggressiveness of America's space policy towards other countries (Hypothesis 5)

\begin{tabular}{|c|c|c|c|}
\hline & Step 1 & Step 2 & Step 3 \\
\hline \multicolumn{4}{|l|}{ Values and Beliefs } \\
\hline Ideology & $-.35 * *$ & $-.33 * * *$ & $-.30 * *$ \\
\hline Internationalism & .13 & .04 & .01 \\
\hline Anti-Americanism & .03 & .10 & .09 \\
\hline \multicolumn{4}{|l|}{ Experimental Conditions } \\
\hline Film & & $.50 * * *$ & $.51 * * *$ \\
\hline Lagged DV & & $.32 * * *$ & $.30 * *$ \\
\hline \multicolumn{4}{|l|}{ Interaction Terms } \\
\hline Film x Ideology & & & .12 \\
\hline Film x Internationalism & & & .13 \\
\hline Film $x$ Anti-Americanism & & & .07 \\
\hline (Constant) & .00 & .00 & .01 \\
\hline \multicolumn{4}{|l|}{ Model Fit } \\
\hline$R^{2}$ & $.11 *$ & $.54 * * *$ & $.57 * * *$ \\
\hline Adjusted $\mathrm{R}^{2}$ & $.07 *$ & $.51 * * *$ & $.52 * * *$ \\
\hline Change in $R^{2}$ & & $.43 * * *$ & .02 \\
\hline
\end{tabular}

Note: Entries are unstandardized coefficients from OLS regression. $N=78$. The dependent variable (DV) was scored $1=$ not at all aggressive to $7=$ very aggressive, with $4=$ not sure. All variables were standardized prior to entry.

${ }^{*} p<.05,{ }^{* *} p<.01,{ }^{* * *} p<.001$. 


\section{Chapter 6: Conclusion}

The purpose of this study was to expand the literature on agenda-setting, priming, and framing effects into the realm of political documentaries. Exploring the effects of a documentary about the weaponization of space in a controlled quasi-experimental setting has produced a number of important findings.

First, the documentary was found to have both first and second-level agenda-setting effects on its viewers. Here, agenda-setting was defined in more traditional terms as 'perceived importance' (implying the conscious processing and weighing of media information) rather than 'salience' (implying the mere recall and use of more accessible information) as recommended in recent studies (Nelson et al., 1997; Takeshita, 2006). When asked to rate the importance of space weaponization, participants viewing the film considered it significantly more important than those who did not. Interestingly, they also rated the issue of nuclear proliferation as significantly more important despite what little attention that issue received in the film. Certain experts in the film even emphasized that the threat of nuclear missiles is diminishing rather than increasing. It may be that images of missiles and missile interceptors were arousing enough to have a greater subsequent impact on judgements than the actual information provided. Newhagen (1992), for instance, found that semantic narrative information is not remembered as well as oral emotion-laden information when conveyed in the presence of compelling images. The results nonetheless coincide with recent findings that agenda-setting effects apply to more than simply news media (Holbrook \& Hill, 2005). In this case, film-maker Denis Delestrac's personal belief about the importance of space weaponization was transferred over to the audience. 
The documentary was also found to have second-level agenda-setting effects because it emphasized the importance of satellite technology. Here, like Craft and Wanta (2004), I defined second-level agenda-setting as the media's ability to make certain attributes of an issue seem more important than others. In this case, attributes of the space weaponization issue were identified as the important benefits derived from satellite technology. This is because the security of satellites - whether military, civilian, or commercial - has been at the core of space weaponization debates since the Rumsfeld Commission first alerted American policymakers in 1998 to the possibility of an attack on American satellites the likes of Pearl Harbour (see Moltz, 2008). Since then, some experts have proposed deploying ground and space-based weapons systems to protect American satellites, while others have warned that this could spark an 'arms race in space.' In either case, proponents and opponents of space weaponization are driven by an underlying concern for the safety of American satellites.

Delestrac's documentary highlights the importance of satellites for providing personal well being and for defending national interests at home and abroad. The film raises concerns about the negative consequences space warfare could have on personal and national interests by threatening the security of American satellites in space. As such, these become central attributes of a larger space weaponization issue.

Results show that viewers were more inclined than non-viewers to consider satellite technology important to their personal way of life after watching the documentary. They also considered satellites to be more important to the "American way of life", indicating heightened awareness about America's growing dependence on satellite technology. Surprisingly, despite emphasizing the American military's reliance on space assets, the documentary had no significant impact on perceived importance of satellites for defending 
North America (i.e. Ballistic Missile Early Warning Systems) or for conducting military operations abroad.

These findings may reflect the amounts of information presented about each attribute. For over a minute, viewers are informed about the many personal benefits derived from satellite technology, including cell phone communication, instant banking, satellite television, weather forecasting, and GPS tracking. This information is also conveyed through images of a woman using, or encountering the use of, these various applications while walking down a city street. By contrast, the military use of satellites is only discussed for half a minute and within the context of American vulnerabilities. That viewers believed satellites were more important to their personal way of life than to the military's operations may perhaps reflect the amount of description each attribute received in the film. This coincides with similar findings (albeit on a different scale) showing that viewers tend to assign more importance to attributes of an issue that receive more coverage by the media (Craft \& Wanta, 2004).

Turning now to priming effects, the experiment revealed no evidence that Masters of Space primed students' attitudes towards President Obama. Here, priming was defined as the media's ability to influence "the standards by which governments, presidents, policies, and candidates for public office are judged" by "calling attention to some matters while ignoring others" (Iyengar \& Kinder, 1987). By highlighting President Obama's funding of counterspace warfare programs (despite having pledged not to weaponize space), the documentary was expected to give viewers negative information on which to evaluate the President. That is, since this information was relatively accessible in memory after the viewing, viewers were expected to rely on it to evaluate their attitudes towards President Obama. 
The results show that viewers were no more likely than non-viewers to base their attitudes towards Obama on his perceived commitment to banning space weapons. In general, participants were more likely to have favourable opinions about the President if they believed he was committed to banning space weapons. However, watching the documentary neither reinforced nor weakened this relationship significantly. Results from this study therefore do no support past findings that other media sources, such as entertainment television (see Holbrook \& Hill, 2005; Holbert et al., 2003) and documentaries (see Holbert \& Hanson, 2006), may influence presidential evaluations.

The lack of priming effects here may reflect a number of factors. Previous studies (see Price and Tewksbury, 1997; Miller \& Krosnick, 1996) suggest the possibility that viewers might simply have deemed the information about President Obama inapplicable to the task of forming an opinion about him. For instance, viewers might have perceived Obama as reluctantly funding these programs while under pressure from military officials and Congress. They therefore might have given the President the benefit of the doubt rather than form negative opinions about him. The information might also have been insufficient to offset fonder recollections about Obama amassed prior to watching the film. In any event, this particular documentary did not have a priming effect on opinions about the President.

Participants did nonetheless appear to rely on information from the documentary to evaluate the prospects of Canadian participation in joint military space projects with the United States. Viewers were more likely than non-viewers to oppose Canada's involvement in missile defence after watching the film. Moreover, the film's impact was greater than, and independent from, other cognitive factors typically relied upon by citizens to form their foreign policy attitudes. Simply put, viewers were more likely to rely on information about 
missile defence presented in the documentary than on left-right ideology, beliefs about international relations, or general attitudes towards the United States.

These effects appear to coincide with the way missile defence is framed in the documentary. Commentators, including the narrator David Suzuki, are highly critical of missile defence. Joseph Cirincione, President of the Ploughshares Fund, calls missile defence "a con" and "the longest running fraud in the history of the Department of Defense" (CBC, 2010a). Bruce Gagnon, a space activist, calls it "a Trojan horse" that will lead to the weaponization of space. Even Suzuki insinuates that missile defence "is another way to fund space weaponry," alluding to the anti-satellite test conducted by the United States military in 2008 using a modified missile defence interceptor.

Amidst the many negative comments, no positive counter-arguments about missile defence are offered in the documentary. In fact, Masters of Space omits interviews with wellknown academic proponents of the system that even appeared in the original full length documentary. Results show that viewers likely relied on these statements to form negative opinions about Canada's participation in the system. The strength and negativity of the statements were apparently enough to persuade viewers to oppose Canadian co-operation in missile defence.

Opposition to missile defence, in this case, was not likely a 'knee-jerk' reaction to negative information, as some might contend. Here, attitudes towards the United States had no bearing on policy evaluations about missile defence. Moreover, viewers seemed far more supportive than non-viewers in developing a system to locate and track space debris after watching the film; something they would likely have opposed if guided by anti-American sentiments. 
Increased support for developing a space debris tracking system once again likely coincides with how space debris is framed in the documentary as "garbage orbiting the Earth" (CBC, 2010a). Suzuki informs viewers that 600,000 pieces of "space garbage," or "space junk," are currently trapped in low Earth orbit. Other experts argue that space debris threatens satellites and may render space inoperable for NASA because of the velocity at which it travels in orbit. Viewers seemed to rely on this information to evaluate the prospects of Canada-United States co-operation in space debris tracking. Those watching the film were thus more likely to support developing a system to locate and track space debris.

On this note, future studies should examine whether public opinion about space debris is correlated with attitudes about the environment on Earth. It may be that framing orbital debris as 'space garbage' activates negative thoughts about land-fills and pollution on Earth, thereby provoking a desire to clean up outer space.

Meanwhile, watching the documentary had no significant impact on other policy evaluations. Viewers were no more in favour or opposed to developing micro-satellite technology with Americans. Nor were they more opposed to developing a system to locate and track foreign satellites. That the film had no impact on these policy preferences may simply reflect its ambiguous framing of those systems as dual-use technology. Microsatellites (the XSS-11 variety), for instance, are framed as useful for identifying problems with older satellites because they can navigate towards and around these satellites and provide engineers with diagnostic video footage. Some experts warn, however, that these diagnostic tools could be used as projectiles for destroying enemy satellites. Meanwhile, the Starfire Optical Laser, once used to research star and satellite tracking capabilities, was also framed as a potential weapon that could be used to target and destroy satellites with optical laser beams. 
It may be that the ambiguous framing of micro-satellites and space tracking systems as 'dual use' technology - neither dedicated weapons nor harmless tools alone- rendered these frames inapplicable for subsequent policy evaluations. For instance, when Brewer and associates (2003) conducted a similar study, exposing students to stories linking terrorism to Iran and drug trafficking to Columbia, they found that "one needs to provide a clear story a frame that explains what issue is at stake and on which side of the issue the foreign nation stands - in order to shape how a mass audience judges another country" (2003: 506). By that logic, perhaps the documentary's inability to frame micro-satellite and space tracking technology as inherently good or bad, harmless or dangerous, rendered this information too ambiguous for activation and subsequent use in evaluating Canada's stance on the issue.

The irony, of course, is that America's Space Surveillance Network (SSN), which tracks space debris, can also be used to locate and track foreign satellites. Furthermore, Canada's Sapphire satellite will feed the SSN with space-based sensor information (Sloan, 2005), thereby involving Canada to some extent in the joint tracking of objects in outer space. Participants in this study were not informed about the SSN and its various capabilities during the study. Instead, they were asked to rate how much they favoured or opposed the prospects of developing with the United States a space debris tracking system, on the one hand, and a foreign satellite tracking system on the other. Watching the documentary increased support for the former, while having no effect on the latter. These findings suggest that framing space surveillance technology as a form of space debris mitigation could help assuage fears that these systems are space weapons in disguise.

Finally, this study found that watching Masters of Space increased the perception that America is pursuing an aggressive space policy towards other countries. Once again, the documentary's impact cuts across any existing core value and beliefs and affects participants 
on both sides of the ideological spectrum. This effect also coincides with Delestrac's intentional framing of the United States as a hegemonic space power bent on dominating low Earth orbit. Here, the documentary completely omits any argument supporting the weaponization of space. For instance, the CBC version omits a scene from the full length documentary depicting experienced military space strategists talking about the inevitability of space weaponization. In that discussion, strategists argue that conflict in space is inevitable because space, as a commons, is becoming increasingly congested with satellites. Moreover, they argue that countries like China, in a position to compete with the United States, recognize America's dependence on space assets and are willing to target this weakness. They also equate space with the sea and argue that countries will eventually develop a military presence in space just as they established sea-faring capabilities in the past. As one strategist puts it: "the same kind of ethics that we apply to military force in the other environments will apply to space..." (Delestrac, 2010).

Rather than include these arguments, which are currently being debated in some academic circles, the CBC version frames the United States as a belligerent hegemonic power intent on denying other countries access to space. As Delectrac put it himself in an interview:

The United States, who own more satellites than the rest of the world combined, are pursuing a space control policy which aims at denying access to space to other nations and controlling the Earth from the "high ground" of space (Delestrac, 2010)

The very title 'Masters of Space', for instance, is interpreted by one activist as meaning America is intent on dominating space. At no time does the film suggest, however, that the 
term implies mastering space: developing a given skill or proficiency at utilizing space as a strategic asset.

The documentary also downplays China's aggressive actions in space while emphasizing those of the United States. For instance, the American anti-satellite test of 2008 is used as an example of space weapons causing orbital debris. In reality, however, the American military deliberately conducted that test at lower altitudes to prevent debris from entering space (Liemer \& Chyba, 2010). Meanwhile, the documentary omits information about the amount of space debris China produced with its anti-satellite test in 2007 , estimated at 950 pieces 4 inches or bigger along with thousands more smaller pieces (Kan, 2007). Near the end of the documentary, French and Russian experts warn that America's actions in space are aggressive and will likely cause their respective countries to respond by deploying their own space-based defences.

Framing America in this light has a direct negative impact on how viewers evaluate the country's national space policy. These results support findings from numerous studies showing that media frames can shape perceptions about countries and their foreign policies (Brewer et al., 2003; Lebart \& McGraw, 1989; Feldman \& Sigelman, 1985). More importantly, when taken together, the overall findings in this study provide strong evidence that a political documentary, like other forms of alternate media, can have significant agendasetting and framing effects on viewers.

Like most studies, this one has its share of limitations. First, relying on undergraduate students to be research participants may raise doubts about the external validity of the findings. It would be naive to simply assume, for instance, that a 21 year old university student would have similar reactions to a documentary as a senior citizen, given their differences in life experience and daily level of exposure to new political ideas. 
However, students are commonly used in these experiments and their use here seems fitting because they are often a target audience for activists and film-makers like Denis Delestrac. The study thus provides some indication that students can be influenced by what they see in political documentaries.

Second, one could argue that the use of classrooms as non-randomized experimental groups renders the findings less conclusive because participants are not randomly selected from the same pool. Although the documentary appears to have certain effects on viewers, the influence of certain extraneous factors associated with being enrolled in those classes could not be fully ruled out. However, the two groups were highly similar in background characteristics and their responses at first measurement did not differ significantly. These factors help strengthen the overall legitimacy of the findings.

Third, the use of a pre-test questionnaire might also raise doubts about the causal impact of the documentary. That is, one might argue that the pre-test questionnaire itself might have sensitized participants to the post-test questionnaire by encouraging them to recall and use their pre-test responses (Sparks, 2006). Since a non-equivalent control group design was used in this experiment, it was deemed necessary to administer a pre-test questionnaire to ensure that the two groups had similar background characteristics. It was also impossible to administer the pre-test questionnaire two or more weeks in advance, as most studies do, because winter-term classes had not yet commenced. But while many scholars are abandoning pre-test questionnaires fearing these skew results (Campbell \& Russo, 1999), sensitization did not reveal itself here in mean differences between pre-test and post-test control group scores.

Fourth, a lack of significant interaction effects may be attributable to the limited number of cases used in the experiment. Methodologists commonly recommend that a 
sample size be $N \geq 50+8 m$ : where $N$ represents the number of cases (participants) and $m$ represents the number of independent variables (predictors) in the model (see Green, 1991; Tabachnik \& Fidell, 2004). By those calculation, the sample in this study is anywhere from 10 to 34 cases short of the optimum size, depending on whether the three interaction terms per model are taken into account. The optimum ratio of cases-to-independent variables is considered higher (40:1) when stepwise regression is used (Tabachnik \& Fidell, 2004). Despite these recommendations, however, it is common for social statisticians to exceed the optimum case-to-IV ratio (Bennett, 2010). Had more participants been available for this study, perhaps the data would have revealed significant interaction effects between the treatment and other cognitive heuristics.

Finally, one factor that should not be overlooked in this study is the influence of David Suzuki. Miller and Krosnick (2000) found that knowledgeable citizens who trust a source of information are more likely to use that information in subsequent evaluations. Sources, in this case, refer to news media at various levels of broadcasting, such as television or radio and local or national. As a media personality for the Canadian Broadcasting Corporation, a national broadcaster on network television, Suzuki himself is likely seen as a credible source of information.

Suzuki, a former professor and geneticist, has been the host of CBC's documentary program The Nature of Things since 1974. His documentaries, including Masters of Space, have long been sold as educational videos for high school and university students. Suzuki's overall popularity has also risen tremendously throughout the decades, earning him the title of fifth "Greatest Canadian" in 2004. Indeed, Suzuki has become somewhat of a national icon and role model for many young Canadians. 
As a political activist, Suzuki has also publicly opposed missile defence since the 1980s and he happens to share the views of many commentators in the film. For instance, Suzuki publicly endorsed activist Steven Staples' campaign against missile defence in 2004 by signing an open letter to Paul Martin (Staples, 2006) ${ }^{9}$. In the documentary, Suzuki claims, like late scientist Carl Sagan and Joseph Cirincione, that he too thought Reagan's plan to shoot down enemy missiles was "non-sense" (CBC, 2010a). Like Sagan, Suzuki has also questioned the effectiveness of ballistic missile defence in his personal writings, claiming the system could be overwhelmed by enemy missiles carrying multiple warheads and be incapable of targeting and intercepting these missiles in a timely manner (Suzuki, 2006).

Moreover, like activist Bruce Gagnon in the film, Suzuki once ridiculed the Bush Administration's justification for wanting to develop a space-based missile defence system, claiming the Administration raised unwarranted fears about an 'Axis of Ev1l.' As he puts it:

Now deprived of an Evil Empire, the Soviet Union, to justify such a costly boondoggle, Bush is left pointing to an Axis of Evil that may include North Korea, Cuba, and who knows who else among this terrifying group- Libya's three million people? Grenada? (Suzuki, 2006)

Here, Suzuki's comments resemble Gagnon's, who argues in the film that the United States government is deceiving the American public into believing countries like North Korea and Iran pose a nuclear threat so that it can justify "moving the arms race into space" (CBC, 2010a). Based on his personal writings, Suzuki appears to share the opinions of

\footnotetext{
${ }^{9}$ Staples appears brefly in the film and claims deploying a missile defence system was one of the Bush Administration's top two pronities immediately after taking office in 2000 .
} 
several commentators in the film concerning missile defence and the weaponization of space.

Given Suzuki's background as a former professor and geneticist, and his popularity as a long time television personality at the $\mathrm{CBC}$, few Canadians would likely dispute that Suzuki is a trusted source of information. Unfortunately, participants in this study were not asked to share their opinions about David Suzuki. However, when asked about Suzuki's documentary, $81 \%$ of all participants watching Masters of Space thought the film was credible, while only $2.6 \%$ ( 1 respondent) believed that it was not. These numbers raise the possibility that Suzuki, as a narrator, may have bolstered the documentary's credibility. His comments about missile defence and other issues in the film may also have guided viewers' reactions and encouraged them to use the information to form their policy evaluations. Future studies could examine Suzuki's influence as an opinion leader in society, especially his impact on attitudes towards the environment.

In the end, as the mass media expands to include the internet, political documentaries like Masters of Space will become increasingly accessible to the masses. Communication scholars and foreign policy-makers should therefore not overlook the impact these documentaries can have on foreign policy attitudes in society. 


\section{References}

Aguinis, H. (2004). Regression Analysis for Categorical Moderators. New York, NY: Guilford Press.

Anderson, J. (2010, July 2). Taking Aim at Real-life Star Wars; Weaponry isn't All about Keeping Peace, Doc Director Says. Toronto Star, E3.

Barbas, T. A., Paraskevopoulos, S. \& Stamou, A. G. (2009). The Effect of Nature Documentaries on Students' Environmental Sensitivity: A Case Study. Learning, Media and Technology 34(1): 61-69.

Bennett, S. E. (2010). An Experimental Study of Opinion on Climate Change: Labile Causalities and Stable Realities. Politics and Policy 38(1): 158-173.

Boese, W. \& Pomper, M. A. (2005). Defending Missile Defence: An Interview with Missile Defence Agency Director Lt. Gen. Obering. Arms Control Today 35(9): 6-11.

Brewer, P. R., Graf, J. \& Willnat, L. (2003). Priming or Framing: Media Influence on Attitudes towards Foreign Countries. International Communication Gaqette 65(6): 493-508.

Burrows, W. E. (1998). This New Ocean: The Story of the First Space Age. New York, NY: Random House.

Campbell, D. T. \& Russo, M. J. (1999). Social Experimentation. Thousand Oaks, CA: Sage.

CBC. (2010a). Masters of Space. The Nature of Things with David Suquki. Toronto, ON: Coptor Productions. Retrieved from http://www.youtube.com/watch?v=FtYQM-QI1NIs.

CBC. (2010b). Masters of Space (Promotional Page). CBC Documentaries (Web Site). Retrieve on 25 Apr. 2011 from http://www.cbc.ca/documentaries/natureofthings/2010/mastersofspace/.

Cohen, B. C. (1963). The Press and Foreign Policy. Princeton, NJ: Princeton UP. 
Craft, S. \& Wanta, W. (2004). U.S. Public Concerns in the Aftermath of 9-11: A Test of Second Level Agenda-Setting. International Journal of Public Opinion Research 16(4): 456-463.

Delestrac, D. (2010). Pax Americana and the Weaponization of Space [Film]. Montreal, QC:

Lowik \& Coptor.

Entman, R. M. (1993). Framing: Toward Clarification of a Fractured Paradigm. Journal of Communication 43(3): 51-58.

Feldman, S. \& Sigelman, L. (1985). The Political Impact of Prime-Time Television: 'The Day After.' Journal of Politics 47(2): 556-578.

Fergusson, J. G. (2010). Canada and Ballistic Missile Defence 1954-2009: Déjà Vu All Over Again. Toronto, ON: UBC Press.

Fitzsimmons, S. J. \& Osburn, H. G. (1968). The Impact of Social Issues and Public Affairs Television Documentaries. Public Opinion Quarterly 32(3): 379-397.

Frederich, R. J. (1982). In Defence of Multiplicative Terms in Multiple Regression Equations. American Journal of Political Science 26(4): 797-833.

Gleeson, P. K. (2007). Perspectives on Space Operations. Astropolitics 5(2): 145-172.

Godefroy, A. B. (2000). Is the Sky Falling? Canada's Defence Space Programme at the Crossroads. Canadian Military Joumal 1(2): 51-58.

Godefroy, A. B. (2006). The Intangible Defence. In Horn, B. LCol. The Canadian Way of War: Serving the National Interest. Toronto, ON: Dundrom.

Green, S. B. (1991). How Many Subjects Does It Take To Do A Regression Analysis? Multivariate Behavioral Research 26(3): 499-510.

Harvey, F. P. (2000). The International Politics of National Missile Defence: A Response to the Critics. International Journal 55(4): 545-566. 
Holbert, R. L., Pillion, O., Tschida, D. A., Armfield, G. G., Kinder, K., Cherry, K. L., \& Daulton, A. R. (2003). The West Wing as Endorsement of the U.S. Presidency: Expanding the Bounds of Priming in Political Communication. Journal of Communication 53(3): 427-443.

Holbert, R. L. \& Hansen, G. J. (2006). Fahrenheit 9-11, Need for Closure and the Priming of Affective Ambivalence: An Assessment of Intra-affective Structures by Party Identification. Human Communication Research 32: 109-129.

Holbrook, A. \& Hill, T. G. (2005). Agenda-Setting and Priming in Prime Time Television: Crime Dramas as Political Cues. Political Communication 22(3): 277-295.

Hurwitz, J. \& Peffley, M. (1987). How are Foreign Policy Attitudes Structured? A Hierarchical Model. American Political Science Review 81(4): 1099-1120.

Iyengar, S. (1990). The Accessibility Bias in Politics: Television News and Public Opinion. International Journal of Public Opinion Research 2(1): 1-15.

Iyengar, S. \& Kinder, M. D. (1987). News that Matters. Chicago: University of Chicago Press. Iyengar, S., Peters, M. D. \& Kinder, D. R. (1982). Experimental Demonstrations of the "Not-So-Minimal" Consequences of Television News Programs. American Political Science Review 76(4): 848-858.

Iyengar, S., Simon, A. (1993). News Coverage of the Gulf Crisis and Public Opinion: A Study of Agenda-Setting, Priming, and Framing. Communication Research 20(3): 365-383.

Jane's Sentinel Security Assessment: North America (2010, January 6). Strategic Weapon Systems, United Stated. Jane's Information Group.

Jenkins-Smith, H. C., Mitchell, N. J. \& Herron, K. G. (2004). Foreign and Domestic Policy Belief Structures in the U.S. and British Publics. Journal of Conflict Resolution 48(3): $287-$ 309. 
Jordan, D. L. \& Page, B. I. (1992). Shaping Foreign Policy Opinions: The Role of TV News. Journal of Conflict Resolution 36(2): 227-241.

Kan, S. (2007, April 23). China's Anti-satellite Weapon Test. CRS Report for Congress. Retrieved from http://www.fas.org/sgp/crs/row/RS22652.pdf.

Kenny, C. (2006, October 13). Ballistic Missile Defence: Our Fear of Americans Trumps any Rational Canadian Approach to Survival. Retrieved from http://colinkenny.ca/.

Kessler, D. J. \& Cour-Palais, B. G. (1978). Collision Frequency of Artificial Satellites: The Creation of a Debris Belt. Joumal of Geophysical Research 83(A6): 2637-2646.

LaMarre, H. L. \& Landreville, K. D. (2009). When is Fiction as Good as Fact? Comparing the Influence of Documentary and Historical Reenactment Films on Engagement, Affect, Issue Interest, and Learning. Mass Communication and Society 12(4): 537-555.

Lenart, S. \& McGraw, K. M. (1989). America Watches "Amerika:" Television Docudrama and Political Attitudes. Journal of Politics 51(3): 697-712.

Liemer, R. \& Chyba, C. F. (2010). A Verifiable Limited Test Ban for Anti-satellite Weapons. The Washington Quarterly 33(3): 149-166.

Lupick, T. (2010, June 1). Denis Delestrac's Pax Americana Delivers History Lesson on Weaponization of Space. Straight.com. Retrieve at http://www.straight.com/article326688/vancouver/director-denis-delestrac-warns-against-weaponization-space-paxamericana.

MacKenzie, F. A. F. (2008). Should Canada Re-examine Its Position on Missile Defence? Canadian Military Journal 9(2): 102-110.

Martin, P. (2008). Hell or High Water: My Life In and Out of Politics. Toronto, ON: McClelland and Stewart. 
McCombs, M., Lopez-Escobar, E. \& Llamas, J. P. (2000). Setting the Agenda of Attributes in the 1996 Spanish General Election. Journal of Communication 50(2): 77-92.

McCombs, M. E., \& Shaw, D. L. (1976). The Agenda-Setting Function of Mass Media. Public Opinion Quarterly 36(2): 176-187.

Miller, J. M., \& Krosnick, J. A. (2000). News Media Impact on the Ingredients of Presidential Evaluations: Politically Knowledgeable Citizens are Guided by a Trusted Source. American Journal of Political Science 44(2): 295-309.

Moltz, J. C. The Politics of Space Security: Strategic Restraint and the Pursuit of National Interests. Stanford, CA: Stanford UP, 2008.

Nelson, T. E., Clawson, R. A. \& Oxley, Z. M. (1997). Media Framing of Civil Liberties Conflict and its Effects on Tolerance. American Political Science Review 91(3): 567-583.

Newhagen, J. E. (1992). The Evening's Bad News: Effects of Compelling Negative Television News Images on Memory. Joumal of Communication 42(2): 25-41.

Nisbet, M. C. \& Aufderheide, P. (2009). Documentary Film: Towards a Research Agenda on Forms, Functions, and Impacts. Mass Communication and Society 12: 450-456.

Nolan, J. M. (2010). “An Inconvenient Truth” Increases Knowledge, Concern, and Willingness to Reduce Greenhouse Gases. Environment and Bebaviour 42(5): 643-658.

Pax Americana and the Weaponization of Space [Official Web Site]. (2010). Interview with Denis Delestrac, Director of Pax Americana. Retrieved Apr. 25, 2011, from http://www.paxamericana.com/qadirector.html.

Peffley, M. A. \& Hurwitz, J. (1985). A Hierarchical Model of Attitude Constraint. American Journal of Political Science 29(4): 871-890.

Penn, D. L., Chamberlin, C. \& Mueser, K. T. (2003). The Effects of a Documentary Film about Schizophrenia on Psychiatric Stigma. Schirophrenia Bulletin 29(2): 383-391. 
Price, V. \& Tewksbury, D. (1997a). News Values and Public Opinion: A Theoretical Account of Media Priming and Framing. In G. Barnett \& Boster (Eds.), Progress in Communication Sciences (pp. 173-212). Norwood, NJ: Ablex.

Price, V., Tewksbury, D., \& Powers, E. (1997b). Switching Trains of Thought: The Impact of News Frames on Readers' Cognitive Responses. Communication Research 24(5): 481506.

Roskos-Ewoldsen, D. R., Roskos-Ewoldsen, B. \& Dillman Carpentier, F. R. D. (2002). Media Priming: A Synthesis. In J. Bryant \& D. Zillman ( $2^{\text {nd }}$ Eds.), Media Effect: Advances in Theory and Research (pp. 97-120). Mahwah (NJ): Lawrence Erlbaum.

Scheufele, D. A. (1999). Framing as a Theory of Media Effects. Journal of Communication 49(1): 103-122.

Scheufele, D. A. (2000). Agenda-Setting, Priming, and Framing Revisited: Another Look at Cognitive Effects of Political Communication. Mass Communication and Society, 3(2): 297316.

Scheufele, D. A. \& Tewksbury, D. (2007). Framing, Agenda-Setting, and Priming: The Evolution of Three Media Effects Models. Journal of Communication 57(1): 9-20.

Seaver, B. M. (1998). The Public Dimension of Foreign Policy. International Journal of Press/Politics 3(1): 65-91.

Shah, D. V., McLeod, D. M., Gotlieb, M. R. \& Lee, N.J. (2009). Framing and Agenda Setting. In R. L. Nabi and M. B. Oliver (Ed.), The Sage Handbook, of Media Processes and Effects (pp. 83-98). Washington (DC): Sage.

Sloan, E. (2005). Security and Defence in the Terrorist Era. Montreal, QC: McGill-Queens UP. Soroka, S. N. (2003). Media, Public Opinion, and Foreign Policy. Press/Politics 8(1): 27-48. 
Sparks, G. G. (2006). Media Effects Research: A Basic Overview. $2^{\text {nd }}$ ed. Toronto, ON: Thomson Wadsworth.

Staples, S. (2006). Missile Defence: Round One. Toronto: Lorimer \& Co.

Stoddard, J. D. (2009). The Ideological Implications of Using “Educational” Film to Teach Controversial Events. Curriculum Inquiry 39(3): 407-433.

Stone, J. (2010, June 6). Pax Americana took Director from Filmmaker to Activist. Vancouver Sun, D10.

Suzuki, D. (2006). David Su₹uki: The Autobiography. Toronto, ON: Greystone.

Tabachnick, B. G. \& Fidell, L. S. (2007). Using Multivariate Statistics. $5^{\text {th }}$ ed. Toronto: Pearson Education.

Takeshita, T. (2006). Current Critical Problems in Agenda-Setting Research. International Journal of Public Opinion Research 18(3): 275-296.

Weaver, D. H. (2007). Thoughts on Agenda Setting, Framing, and Priming. Journal of Communication 57(1): 142-147.

Weeden, B. (2011). Overview of the Legal and Policy Challenges of Orbital Debris Removal. Space Policy 27.1: 38-43.

Williams, C. A., Salzman, A., Vantine, W., Suelter, L., Baker, A., Bonvouloir, L., Brenner, B., Ely, M., Feldman, J. \& Ziegel, R. (1985). The Power of the Right Stuff: A QuasiExperimental Field Test of the Docudrama Hypothesis. Public Opinion Quarterly 49(3): 330-339.

Wyer, R. S., \& Srull, T. K. (1986). Human Cognition in its Social Context. Psycbological Review 93(3): 322-359. 


\section{Appendix A: Letter of Information (Control Group)}

Dear student,

Thank you for agreeing to participate in this study being conducted by myself, François Nadeau (Masters Candidate), under the supervision of Dr. Scott E. Bennett of the Department of Political Science. Please note that you are under no obligation to participate and you may withdraw your participation at any time PRIOR TO OR DURING THE EXPERIMENT.

The purpose of this study is to measure how people respond to certain messages they might encounter in the mass media. During the course of this particular experiment, you will be asked to fill out a brief questionnaire soliciting your thoughts and opinions about a random political issue of the day (i.e. "How strongly do you feel about this issue?").

Under no circumstances will you be photographed or recorded on video or audio devices. You will not be subjected to any deliberate risks, discomforts, and/or inconveniences of a physical, psychological, emotional, economic, or social nature.

Under no circumstances will another party other than the researcher and his supervisor have access to your information. You will be asked at the end of the experiment whether you would agree to be contacted by e-mail for a follow up study. You are, once again, under no obligation to accept.

The research findings will be accessible through Carleton University after my thesis has been published. The data will remain in my possession following the completion of the study. It will be stored on a disk and it will not be shared with any third party. The data could be reused in the future in my graduate work at the $\mathrm{PhD}$ level.

This study was reviewed and received ethics clearance by the Carleton University Research Ethics Board. If you have any questions or concerns about this study, you may contact the chair of the Research Ethics Board at the address below: 
Prof. Antonio Gualtieri, Chair

Carleton University Research Ethics Board

Carleton University

1125 Colonel By Drive

Ottawa, ON

K1S 5B6

613-520-2517

ethics@carleton.ca

We thank you once again for your participation.

Sincerely,

\section{François Nadeau}

Masters Candidate (Primary Researcher)

Department of Political Science

E-mail: fnadeau(connect.carleton.ca
Dr. Scott E. Bennett

Professor (Supervisor)

Department of Political Science

E-mail: sbennett@ccs.carleton.ca

\section{Consent Form}

\section{Participant}

I, __ have read the above letter and understand that I am participating in a research project and I voluntarily agree to participate.

\section{Researcher}

I, the researcher, have read the above letter and understand that I am conducting a research project and I voluntarily agree to participate. 


\title{
Appendix B: Letter of Information (Treatment Group)
}

\author{
Dear student,
}

Thank you for agreeing to participate in this study being conducted by myself, François Nadeau (Masters Candidate), under the supervision of Dr. Scott Bennett of the Department of Political Science. Please note that you are under no obligation to participate and you may withdraw your participation at any time PRIOR TO OR DURING THE EXPERIMENT.

The purpose of this study is to measure how people respond to certain messages they might encounter in the mass media. During the course of this particular experiment, you will be asked to fill out a brief questionnaire soliciting your thoughts and opinions about a random political issue of the day (i.e. "How strongly do you feel about this issue?") and watch a 43 minute documentary in between.

Under no circumstances will you be photographed or recorded on video or audio devices. You will not be subjected to any deliberate risks, discomforts, and/or inconveniences of a physical, psychological, emotional, economic, or social nature.

Under no circumstances will another party other than the researcher and his supervisor have access to your information. You will be asked at the end of the experiment whether you would agree to be contacted by e-mail for a follow up study. You are, once again, under no obligation to accept.

The research findings will be accessible through Carleton University after my thesis has been published. The data will remain in my possession following the completion of the study. It will be stored on a disk and it will not be shared with any third party. The data could be reused in the future in my graduate work at the $\mathrm{PhD}$ level.

This study was reviewed and received ethics clearance by the Carleton University Research Ethics Board. If you have any questions or concerns about this study, you may contact the chair of the Research Ethics Board at the address below: 
Prof. Antonio Gualtieri, Chair

Carleton University Research Ethics Board

Carleton University

1125 Colonel By Drive

Ottawa, ON

K1S 5B6

613-520-2517

ethics@carleton.ca

We thank you once again for your participation.

Sincerely,

François Nadeau

Masters Candidate (Primary

Researcher)

Department of Political Science

E-mail: fnadeau@connect.carleton.ca
Dr. Scott Bennett

Professor (Supervisor)

Department of Political Science

E-mail: sbennett@,ccs.carleton.ca

\section{Consent Form}

\section{Participant}

I, __ have read the above letter and understand that I am participating in a research project and I voluntarily agree to participate.

\section{Researcher}

I, the researcher, have read the above letter and understand that I am conducting a research project and I voluntarily agree to participate. 


\section{Appendix C: Pre-Test Questionnaire}

1. On a scale of 1 to 7 , how interested are you in international affairs? (circle answer)

\begin{tabular}{lllllll} 
Not at all & & $\begin{array}{c}\text { Not } \\
\text { Sure }\end{array}$ & & & $\begin{array}{r}\text { Very } \\
\text { Interested }\end{array}$ \\
1 & 2 & 3 & 4 & 5 & 6 & 7 \\
\hline
\end{tabular}

2. And on a similar scale, how knowledgeable are you about international affairs?

\begin{tabular}{llccccc} 
Not at all & & $\begin{array}{c}\text { Not } \\
\text { Sure }\end{array}$ & & \multicolumn{2}{r}{$\begin{array}{r}\text { Very } \\
\text { Interested }\end{array}$} \\
1 & 2 & 3 & 4 & 5 & 6 & 7 \\
\hline
\end{tabular}

3. Thus far, as a student, have you taken any classes on international affairs?

$\square \quad$ Yes

$\square \quad$ No

4. And have you taken any classes on national defence?

$\square \quad$ Yes

$\square \quad$ No

5. How many years of post-secondary education have you completed up to now? (Please write number)

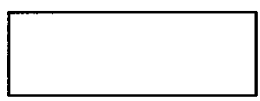

6. Is your current degree in political science?

$\square \quad$ Yes

$\square \quad$ No

7. If so, what is your concentration:

International relations

Canadian politics

Other

None
8. In your opinion, how important is the issue of nuclear proliferation?

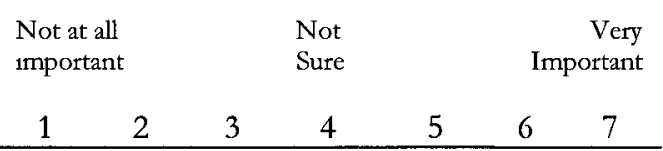

9. And how important is the issue of space weaponization?

$\begin{array}{llllllr}\begin{array}{l}\text { Not at all } \\ \text { Important }\end{array} & & \begin{array}{l}\text { Not } \\ \text { Sure }\end{array} & & & \begin{array}{r}\text { Very } \\ \text { Important }\end{array} \\ 1 & 2 & 3 & 4 & 5 & 6 & 7\end{array}$

10. In general, how important or unimportant do you feel space satellites are to:

a. Your personal way of life?

\begin{tabular}{lrrrrrr}
$\begin{array}{l}\text { Not at all } \\
\text { important }\end{array}$ & & $\begin{array}{l}\text { Not } \\
\text { Sure }\end{array}$ & & & rery \\
Important \\
1 & 2 & 3 & 4 & 5 & 6 & 7 \\
\hline
\end{tabular}

b. The American way of life?

\begin{tabular}{lrrrrrr}
$\begin{array}{l}\text { Not at all } \\
\text { important }\end{array}$ & & $\begin{array}{l}\text { Not } \\
\text { Sure }\end{array}$ & & \multicolumn{3}{r}{$\begin{array}{r}\text { Very } \\
\text { Important }\end{array}$} \\
1 & 2 & 3 & 4 & 5 & 6 & 7 \\
\hline
\end{tabular}

c. The Defence of North America?

\begin{tabular}{lrrrrrr}
$\begin{array}{l}\text { Not at all } \\
\text { important }\end{array}$ & & $\begin{array}{l}\text { Not } \\
\text { Sure }\end{array}$ & & & \multicolumn{2}{r}{$\begin{array}{r}\text { Very } \\
\text { Important }\end{array}$} \\
1 & 2 & 3 & 4 & 5 & 6 & 7 \\
\hline
\end{tabular}

d. American military operations abroad?

\begin{tabular}{lrrrrrr}
$\begin{array}{l}\text { Not at all } \\
\text { mpportant }\end{array}$ & & $\begin{array}{l}\text { Not } \\
\text { Sure }\end{array}$ & & & $\begin{array}{r}\text { Very } \\
\text { Important }\end{array}$ \\
1 & 2 & 3 & 4 & 5 & 6 & 7 \\
\hline
\end{tabular}


11. Canada and the United States have worked together on a number of defence projects since the end of World War II. Looking forward, to what extent would you favour or oppose Canada participating in the following projects:

\begin{tabular}{|c|c|c|c|c|c|c|}
\hline a. & \multicolumn{6}{|c|}{$\begin{array}{l}\text { Developing a system to locate and } \\
\text { track the satellites of other countries? }\end{array}$} \\
\hline Strongly & & & Not & & & ngly \\
\hline Oppose & & & Sure & & & rour \\
\hline 1 & 2 & 3 & 4 & 5 & 6 & 7 \\
\hline
\end{tabular}

b. Developing a system to locate and track space debris?

\begin{tabular}{ccccccc}
$\begin{array}{l}\text { Strongly } \\
\text { Oppose }\end{array}$ & & $\begin{array}{c}\text { Not } \\
\text { Sure }\end{array}$ & & & \multicolumn{2}{c}{$\begin{array}{c}\text { Strongly } \\
\text { Favour }\end{array}$} \\
1 & 2 & 3 & 4 & 5 & 6 & 7 \\
\hline
\end{tabular}

c. Developing a missile defence system to defend against incoming ballistic missiles?

\begin{tabular}{lllcccc}
$\begin{array}{l}\text { Strongly } \\
\text { Oppose }\end{array}$ & & $\begin{array}{c}\text { Not } \\
\text { Sure }\end{array}$ & & & $\begin{array}{c}\text { Strongly } \\
\text { Favour }\end{array}$ \\
1 & 2 & 3 & 4 & 5 & 6 & 7 \\
\hline
\end{tabular}

d. Developing smaller 'microsatellites' that can navigate towards and around other satellites?

$\begin{array}{llr}\text { Strongly } & \text { Not } & \text { Strongly } \\ \text { Oppose } & \text { Sure } & \text { Favour }\end{array}$

\begin{tabular}{lllllll}
1 & 2 & 3 & 4 & 5 & 6 & 7 \\
\hline
\end{tabular}

12. In your opinion, how closely should the Canadian Department of National Defence (DND) work with the American Department of Defense (DoD) on developing military technology to defend the space satellites of each country?

\begin{tabular}{lllllll} 
Not at all & & $\begin{array}{c}\text { Not } \\
\text { Sure }\end{array}$ & & \multicolumn{2}{r}{$\begin{array}{r}\text { Very } \\
\text { Closely }\end{array}$} \\
1 & 2 & 3 & 4 & 5 & 6 & 7 \\
\hline
\end{tabular}

13. How favourable or unfavourable are your opinions about President Barack Obama?

\begin{tabular}{|c|c|c|c|c|c|c|}
\hline \multicolumn{3}{|c|}{ Very } & \multicolumn{2}{|c|}{ Not } & \multirow{2}{*}{\multicolumn{2}{|c|}{ Very }} \\
\hline Unfa & & & Sure & & & rable \\
\hline 1 & 2 & 3 & 4 & 5 & 6 & 7 \\
\hline
\end{tabular}

14. How favourable or unfavourable are your opinions about the United States?

\begin{tabular}{lrrrrrr}
$\begin{array}{l}\text { Very } \\
\text { Unfavourable }\end{array}$ & & $\begin{array}{l}\text { Not } \\
\text { Sure }\end{array}$ & & \multicolumn{2}{r}{$\begin{array}{r}\text { Very } \\
\text { Favourable }\end{array}$} \\
1 & 2 & 3 & 4 & 5 & 6 & 7 \\
\hline
\end{tabular}

15. And how favourable or unfavourable are your opinions about Americans?

\begin{tabular}{lrrrrrr}
$\begin{array}{l}\text { Very } \\
\text { Unfavourable }\end{array}$ & $\begin{array}{c}\text { Not } \\
\text { Sure }\end{array}$ & & & $\begin{array}{r}\text { Very } \\
\text { Favourable }\end{array}$ \\
1 & 2 & 3 & 4 & 5 & 6 & 7 \\
\hline
\end{tabular}

16. In your opinion, how committed or uncommitted is President Barack Obama to banning weapons in space?

\begin{tabular}{llllllr}
$\begin{array}{l}\text { Not at all } \\
\text { Committed }\end{array}$ & & $\begin{array}{l}\text { Not } \\
\text { Sure }\end{array}$ & & & $\begin{array}{r}\text { Very } \\
\text { Committed }\end{array}$ \\
1 & 2 & 3 & 4 & 5 & 6 & 7 \\
\hline
\end{tabular}

17. And in your opinion, how aggressive or non-aggressive would you say that the United States' space policy is towards other countries?

\begin{tabular}{lllllll}
$\begin{array}{l}\text { Not at all } \\
\text { aggressive }\end{array}$ & & $\begin{array}{l}\text { Not } \\
\text { Sure }\end{array}$ & & \multicolumn{2}{r}{$\begin{array}{r}\text { Very } \\
\text { Aggressive }\end{array}$} \\
1 & 2 & 3 & 4 & 5 & 6 & 7 \\
\hline
\end{tabular}

18. Some people worry that American military satellites are vulnerable to an attack the likes of 'Pearl Harbour'. In your opinion how likely or unlikely is it that another country would attack American military satellites in the future?

\begin{tabular}{lrrrrrr}
$\begin{array}{l}\text { Not at all } \\
\text { Likely }\end{array}$ & & $\begin{array}{l}\text { Not } \\
\text { Sure }\end{array}$ & & & & Very \\
Likely \\
1 & 2 & 3 & 4 & 5 & 6 & 7 \\
\hline
\end{tabular}


19. Some people worry that the United States will be vulnerable to nuclear missiles launched by hostile states. In your opinion, how likely or unlikely is it that another country would launch a nuclear missile at the U.S. in the future?

$\begin{array}{lrrrrrr}\begin{array}{l}\text { Not at all } \\ \text { Likely }\end{array} & & \begin{array}{l}\text { Not } \\ \text { Sure }\end{array} & & & \text { Very } \\ \text { Likely }\end{array}$

20. Some argue that weapon systems will inevitably be deployed in space, while others argue this can be prevented. How likely or unlikely would you say that weapons will be deployed in space?

\begin{tabular}{llrllll}
$\begin{array}{l}\text { Not at all } \\
\text { Likely }\end{array}$ & & $\begin{array}{l}\text { Not } \\
\text { Sure }\end{array}$ & & \multicolumn{2}{c}{ Very Likely } \\
1 & 2 & 3 & 4 & 5 & 6 & 7 \\
\hline
\end{tabular}

21. In general, which federal political party do you usually prefer?

$\begin{array}{ll}\square & \text { Liberals } \\ \square & \text { Conservatives } \\ \square & \text { Bloc } \\ \square & \text { NDP } \\ \square & \text { Greens } \\ \square & \text { Other } \\ \square & \text { None } \\ \square & \text { Don't know }\end{array}$

22. Some people talk about politics in terms of left, center, and right. On a seven-point left-right scale, 1 indicating extreme left and 7 indicating extreme right, where do you place yourself?

\begin{tabular}{llllllll} 
Far left & & & $\begin{array}{c}\text { Not } \\
\text { Sure }\end{array}$ & & & Far nght \\
1 & 2 & 3 & 4 & 5 & 6 & 7 \\
\hline
\end{tabular}

23. On a scale ranging from 1 (strongly disagree) to 7 (strongly agree), please respond to the following statements: a. In today's world, every country has to take care of itself.

\begin{tabular}{llllllc}
$\begin{array}{l}\text { Strongly } \\
\text { Disagree }\end{array}$ & & $\begin{array}{l}\text { Not } \\
\text { Sure }\end{array}$ & & & $\begin{array}{r}\text { Strongly } \\
\text { Agree }\end{array}$ \\
1 & 2 & 3 & 4 & 5 & 6 & 7 \\
\hline
\end{tabular}
b. It is not important for Canada to promote world peace.

\begin{tabular}{llllllr}
$\begin{array}{l}\text { Strongly } \\
\text { Disagree }\end{array}$ & & $\begin{array}{l}\text { Not } \\
\text { Sure }\end{array}$ & & & \multicolumn{2}{r}{$\begin{array}{r}\text { Strongly } \\
\text { Agree }\end{array}$} \\
1 & 2 & 3 & 4 & 5 & 6 & 7 \\
\hline
\end{tabular}

24. What is your gender?

$\square$ Male
$\square \quad$ Female

25. What is your age range?
$\square \quad 17-18$ years
$\square \quad 19-20$ years
$\square \quad 21-22$ years
$\square \quad 23-24$ years
$\square \quad 25$ years and over

26. Were you born in Canada?

$$
\begin{aligned}
& \square \quad \text { Yes } \\
& \square \quad \text { No }
\end{aligned}
$$

27. Was at least one of your parents born in Canada?

$$
\begin{array}{ll}
\square \quad \text { Yes } \\
\square \quad \text { No }
\end{array}
$$

28. Which province do you call home?
$\square$ Prince Edward Island
$\square \quad$ Newfoundland
$\square \quad$ Nova Scotia
$\square \quad$ New Brunswick
$\square \quad$ Quebec
$\square \quad$ Ontario
$\square \quad$ Manitoba
$\square$ Saskatchewan
$\square \quad$ Alberta
$\square \quad$ British Columbia
$\square \quad$ Northwest Territories ${ }^{10}$

${ }^{10}$ A $29^{\text {th }}$ question looked at how religious participants considered themselves. Participants were asked to ignore it because the scale was incorrectly labelled. 


\section{Appendix D: Post-Test Questionnaire}

29. Had you seen the CBC documentary Masters of Space before today?

$$
\begin{array}{ll}
\square \quad \text { Yes } \\
\square \quad \text { No } \\
\square \quad \text { Don't Know }
\end{array}
$$

30. In your opinion, how credible or noncredible is the information presented in this documentary?

\begin{tabular}{lllllll}
$\begin{array}{l}\text { Not at all } \\
\text { credible }\end{array}$ & & $\begin{array}{l}\text { Not } \\
\text { Sure }\end{array}$ & & \multicolumn{3}{r}{$\begin{array}{r}\text { Very } \\
\text { credible }\end{array}$} \\
1 & 2 & 3 & 4 & 5 & 6 & 7 \\
\hline
\end{tabular}

31. Have you seen the documentary Pax Americana and the Weaponization of Space?

$\begin{array}{ll}\square & \text { Yes } \\ \square & \text { No } \\ \square & \text { Don't Know }\end{array}$

32. In your opinion, how important is the issue of nuclear proliferation?

\begin{tabular}{lllllll}
$\begin{array}{l}\text { Not at all } \\
\text { Important }\end{array}$ & & $\begin{array}{l}\text { Not } \\
\text { Sure }\end{array}$ & & \multicolumn{2}{r}{$\begin{array}{r}\text { Very } \\
\text { Important }\end{array}$} \\
1 & 2 & 3 & 4 & 5 & 6 & 7 \\
\hline
\end{tabular}

\begin{tabular}{|c|c|c|c|c|c|c|}
\hline \multicolumn{2}{|c|}{$\begin{array}{l}\text { Not at all } \\
\text { important }\end{array}$} & \multicolumn{3}{|c|}{$\begin{array}{l}\text { Not } \\
\text { Sure }\end{array}$} & \multicolumn{2}{|c|}{$\begin{array}{r}\text { Very } \\
\text { Important }\end{array}$} \\
\hline 1 & 2 & 3 & 4 & 5 & 6 & 7 \\
\hline
\end{tabular}

33. And how important is the issue of space weaponization?

34. In general, how important or unimportant do you feel space satellites are to:

a. Your personal way of life?

\begin{tabular}{|c|c|c|c|c|c|c|}
\hline \multicolumn{2}{|c|}{$\begin{array}{l}\text { Not at all } \\
\text { 1mportant }\end{array}$} & \multicolumn{3}{|c|}{$\begin{array}{l}\text { Not } \\
\text { Sure }\end{array}$} & \multicolumn{2}{|c|}{$\begin{array}{r}\text { Very } \\
\text { Important }\end{array}$} \\
\hline 1 & 2 & 3 & 4 & 5 & 6 & 7 \\
\hline c. & \multicolumn{6}{|c|}{ The Defence of North America? } \\
\hline \multicolumn{2}{|c|}{$\begin{array}{l}\text { Not at all } \\
\text { important }\end{array}$} & \multicolumn{3}{|c|}{$\begin{array}{l}\text { Not } \\
\text { Sure }\end{array}$} & \multicolumn{2}{|c|}{$\begin{array}{r}\text { Very } \\
\text { Important }\end{array}$} \\
\hline 1 & 2 & 3 & 4 & 5 & 6 & 7 \\
\hline
\end{tabular}

\begin{tabular}{lllllll}
$\begin{array}{l}\text { Not at all } \\
\text { Important }\end{array}$ & $\begin{array}{l}\text { Not } \\
\text { Sure }\end{array}$ & & \multicolumn{3}{r}{$\begin{array}{r}\text { Very } \\
\text { Important }\end{array}$} \\
1 & 2 & 3 & 4 & 5 & 6 & 7 \\
\hline
\end{tabular}

b. The American way of life?

d. American military operations abroad?

\begin{tabular}{lrrrrrr}
$\begin{array}{l}\text { Not at all } \\
\text { Important }\end{array}$ & $\begin{array}{l}\text { Not } \\
\text { Sure }\end{array}$ & & \multicolumn{2}{r}{$\begin{array}{r}\text { Very } \\
\text { Important }\end{array}$} \\
1 & 2 & 3 & 4 & 5 & 6 & 7 \\
\hline
\end{tabular}

35. (Question removed)

36. (Question removed)

37. Canada and the United States have worked together on a number of defence projects since the end of World War II. Looking forward, to what extent would you favour or oppose Canada participating in the following projects:

a. Developing a system to locate and track the satellites of other countries?

\begin{tabular}{lllllll}
$\begin{array}{l}\text { Strongly } \\
\text { Oppose }\end{array}$ & & $\begin{array}{l}\text { Not } \\
\text { Sure }\end{array}$ & & \multicolumn{3}{c}{$\begin{array}{c}\text { Strongly } \\
\text { Favour }\end{array}$} \\
1 & 2 & 3 & 4 & 5 & 6 & 7 \\
\hline
\end{tabular}


b. Developing a system to locate and track space debris?

\begin{tabular}{lllllll}
$\begin{array}{l}\text { Strongly } \\
\text { Oppose }\end{array}$ & & $\begin{array}{l}\text { Not } \\
\text { Sure }\end{array}$ & & \multicolumn{2}{r}{$\begin{array}{r}\text { Strongly } \\
\text { Favour }\end{array}$} \\
1 & 2 & 3 & 4 & 5 & 6 & 7 \\
\hline
\end{tabular}

c. Developing a missile defence system to defend against incoming ballistic missiles?

\begin{tabular}{lllllll}
$\begin{array}{l}\text { Strongly } \\
\text { Oppose }\end{array}$ & & $\begin{array}{l}\text { Not } \\
\text { Sure }\end{array}$ & & & \multicolumn{2}{c}{$\begin{array}{r}\text { Strongly } \\
\text { Favour }\end{array}$} \\
1 & 2 & 3 & 4 & 5 & 6 & 7 \\
\hline
\end{tabular}

d. Developing smaller 'microsatellites' that can navigate towards and around other satellites?

\begin{tabular}{lllllll}
$\begin{array}{l}\text { Strongly } \\
\text { Oppose }\end{array}$ & & $\begin{array}{l}\text { Not } \\
\text { Sure }\end{array}$ & & & \multicolumn{2}{c}{$\begin{array}{c}\text { Strongly } \\
\text { Favour }\end{array}$} \\
1 & 2 & 3 & 4 & 5 & 6 & 7 \\
\hline
\end{tabular}

38. In your opinion, how closely should the Canadian Department of National Defence (DND) work with the American Department of Defense (DoD) on developing military technology to defend the space satellites of each country?

\begin{tabular}{lllllll} 
Not at all & & $\begin{array}{l}\text { Not } \\
\text { Sure }\end{array}$ & & \multicolumn{3}{r}{$\begin{array}{r}\text { Very } \\
\text { Closely }\end{array}$} \\
1 & 2 & 3 & 4 & 5 & 6 & 7 \\
\hline
\end{tabular}

39. How favourable or unfavourable are your opinions about President Barack Obama?

\begin{tabular}{lllllll}
$\begin{array}{l}\text { Very } \\
\text { Unfavourable }\end{array}$ & $\begin{array}{l}\text { Not } \\
\text { Sure }\end{array}$ & & \multicolumn{2}{r}{$\begin{array}{r}\text { Very } \\
\text { Favourable }\end{array}$} \\
1 & 2 & 3 & 4 & 5 & 6 & 7 \\
\hline
\end{tabular}

40. How favourable or unfavourable are your opinions about the United States?

\begin{tabular}{lllllll}
$\begin{array}{l}\text { Very } \\
\text { Unfavourable }\end{array}$ & $\begin{array}{l}\text { Not } \\
\text { Sure }\end{array}$ & & \multicolumn{2}{r}{$\begin{array}{r}\text { Very } \\
\text { Favourable }\end{array}$} \\
1 & 2 & 3 & 4 & 5 & 6 & 7 \\
\hline
\end{tabular}

41. And how favourable or unfavourable are your opinions about Americans?

\begin{tabular}{lllllll}
$\begin{array}{l}\text { Very } \\
\text { Unfavourable }\end{array}$ & & $\begin{array}{l}\text { Not } \\
\text { Sure }\end{array}$ & & \multicolumn{2}{r}{$\begin{array}{r}\text { Very } \\
\text { Favourable }\end{array}$} \\
1 & 2 & 3 & 4 & 5 & 6 & 7 \\
\hline
\end{tabular}

42. In your opinion, how committed or un-committed is President Barack Obama to banning weapons in space?

\begin{tabular}{lllllll}
$\begin{array}{l}\text { Not at all } \\
\text { Committed }\end{array}$ & $\begin{array}{l}\text { Not } \\
\text { Sure }\end{array}$ & & \multicolumn{2}{r}{$\begin{array}{r}\text { Very } \\
\text { Committed }\end{array}$} \\
1 & 2 & 3 & 4 & 5 & 6 & 7 \\
\hline
\end{tabular}

43. And in your opinion, how aggressive or non-aggressive would you say that the United States' space policy is towards other countries?

\begin{tabular}{lllllll}
$\begin{array}{l}\text { Not at all } \\
\text { aggressive }\end{array}$ & & $\begin{array}{l}\text { Not } \\
\text { Sure }\end{array}$ & & \multicolumn{2}{r}{$\begin{array}{r}\text { Very } \\
\text { Aggressive }\end{array}$} \\
1 & 2 & 3 & 4 & 5 & 6 & 7 \\
\hline
\end{tabular}

44. Some people worry that American military satellites are vulnerable to an attack the likes of 'Pearl Harbour'. In your opinion how likely or unlikely is it that another country would attack American military satellites in the future?

\begin{tabular}{llllllc}
$\begin{array}{l}\text { Not at all } \\
\text { Likely }\end{array}$ & & $\begin{array}{l}\text { Not } \\
\text { Sure }\end{array}$ & & & $\begin{array}{r}\text { Very } \\
\text { Lkely }\end{array}$ \\
1 & 2 & 3 & 4 & 5 & 6 & 7 \\
\hline
\end{tabular}


45. Some people worry that the United States will be vulnerable to nuclear missiles launched by hostile states. In your opinion, how likely or unlikely is it that another country would launch a nuclear missile at the U.S. in the future?

\begin{tabular}{lrrrrrr}
$\begin{array}{l}\text { Not at all } \\
\text { Likely }\end{array}$ & & $\begin{array}{l}\text { Not } \\
\text { Sure }\end{array}$ & & & $\begin{array}{r}\text { Very } \\
\text { Likely }\end{array}$ \\
1 & 2 & 3 & 4 & 5 & 6 & 7 \\
\hline
\end{tabular}

46. Some argue that weapon systems will inevitably be deployed in space, while others argue this can be prevented. How likely or unlikely would you say that weapons will be deployed in space?

\begin{tabular}{lrrrrrr}
$\begin{array}{l}\text { Not at all } \\
\text { Likely }\end{array}$ & & $\begin{array}{l}\text { Not } \\
\text { Sure }\end{array}$ & & & \multicolumn{2}{r}{$\begin{array}{r}\text { Very } \\
\text { Likely }\end{array}$} \\
1 & 2 & 3 & 4 & 5 & 6 & 7 \\
\hline
\end{tabular}

47. To what extent do you agree or disagree with these statements?

\section{a. Several hundred billion dollars worth of assets in space are completely in jeopardy if we begin to put weapons in space.}

\begin{tabular}{|c|c|c|c|c|c|c|}
\hline \multirow{2}{*}{\multicolumn{2}{|c|}{$\begin{array}{l}\text { Strongly } \\
\text { Disagree }\end{array}$}} & \multirow{2}{*}{\multicolumn{3}{|c|}{$\begin{array}{l}\text { Not } \\
\text { Sure }\end{array}$}} & \multirow{2}{*}{\multicolumn{2}{|c|}{$\begin{array}{r}\text { Strongly } \\
\text { Agree }\end{array}$}} \\
\hline & & & & & & \\
\hline 1 & 2 & 3 & 4 & 5 & 6 & 7 \\
\hline
\end{tabular}

b. The United States is pursuing a policy to control the Earth from the "high ground" of space.

\begin{tabular}{lllllllr}
$\begin{array}{l}\text { Strongly } \\
\text { Disagree }\end{array}$ & & $\begin{array}{l}\text { Not } \\
\text { Sure }\end{array}$ & & & $\begin{array}{r}\text { Strongly } \\
\text { Agree }\end{array}$ \\
1 & 2 & 3 & 4 & 5 & 6 & 7 \\
\hline
\end{tabular}

c. We have got to begin to look at space as an environment.

\begin{tabular}{|c|c|c|c|c|c|c|}
\hline \multirow{2}{*}{\multicolumn{2}{|c|}{$\begin{array}{l}\text { Strongly } \\
\text { Disagree }\end{array}$}} & \multirow{2}{*}{\multicolumn{3}{|c|}{$\begin{array}{l}\text { Not } \\
\text { Sure }\end{array}$}} & & ngly \\
\hline & & & & & & gree \\
\hline 1 & 2 & 3 & 4 & 5 & 6 & 7 \\
\hline
\end{tabular}

d. If necessary, the United States should have the right to defend its space satellites even if this means denying other countries the use of their space assets.

\begin{tabular}{lrrrrrr}
$\begin{array}{l}\text { Strongly } \\
\text { Disagree }\end{array}$ & & $\begin{array}{l}\text { Not } \\
\text { Sure }\end{array}$ & & & $\begin{array}{r}\text { Strongly } \\
\text { Agree }\end{array}$ \\
1 & 2 & 3 & 4 & 5 & 6 & 7 \\
\hline
\end{tabular}

e. Countries should work on international treaties to make military space networks used for multilateral purposes.

\begin{tabular}{llllllc}
$\begin{array}{l}\text { Strongly } \\
\text { Disagree }\end{array}$ & & $\begin{array}{l}\text { Not } \\
\text { Sure }\end{array}$ & & \multicolumn{2}{r}{$\begin{array}{r}\text { Strongly } \\
\text { Agree }\end{array}$} \\
1 & 2 & 3 & 4 & 5 & 6 & 7 \\
\hline
\end{tabular}

f. If we move to the weaponization of space, we can bid farewell to the planet because the chances of survival are very slim.

\begin{tabular}{lllllll}
$\begin{array}{l}\text { Strongly } \\
\text { Disagree }\end{array}$ & & $\begin{array}{l}\text { Not } \\
\text { Sure }\end{array}$ & & \multicolumn{2}{r}{$\begin{array}{r}\text { Strongly } \\
\text { Agree }\end{array}$} \\
1 & 2 & 3 & 4 & 5 & 6 & 7 \\
\hline
\end{tabular}

g. The debate over space weaponization is the most critical debate of the next century.

\begin{tabular}{lllllll}
$\begin{array}{l}\text { Strongly } \\
\text { Disagree }\end{array}$ & & $\begin{array}{l}\text { Not } \\
\text { Sure }\end{array}$ & & \multicolumn{2}{c}{$\begin{array}{r}\text { Strongly } \\
\text { Agree }\end{array}$} \\
1 & 2 & 3 & 4 & 5 & 6 & 7 \\
\hline
\end{tabular}

48. In general, do you favour or oppose space weapons?

$\square$ Favour

Oppose

Not sure 
49. If you answered 'oppose' at Question 23 , which of the following weapons or potential weapons do you oppose the most?

$\square \quad$ STARFIRE Ground-based laser

$\square \quad$ SM-3 missile interceptors

$\square \quad X S S-11$ Microsatellites

$\square \quad$ Falcon space plane

$\square$ Rods from God orbital bombardment

$\square \quad$ None

$\square \quad$ Not sure

$\square$ Don't know

50. And why that weapon? (Please write)

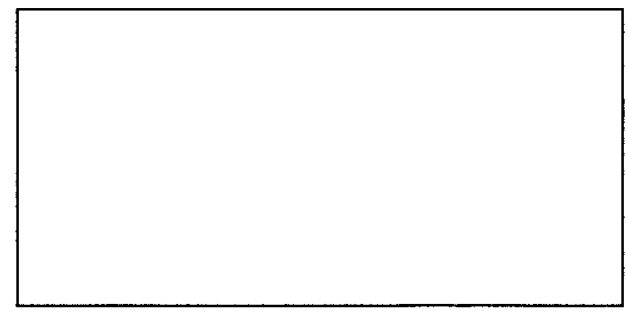




\section{Appendix E: Ethics Clearance Form}
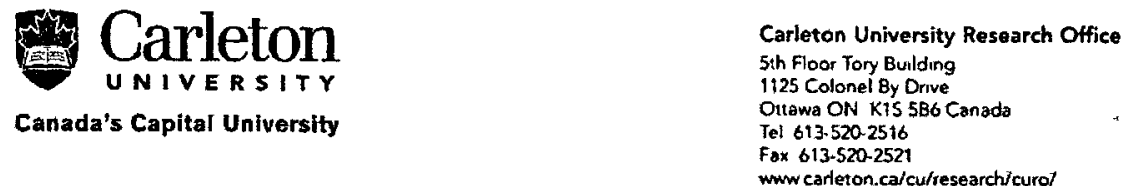

\section{Ethics Clearance Form}

This is to certify that the Carleton University Research Ethics Board has examined the application for ethical clearance. The REB found the research project to meet appropriate ethical standards as outlined in the Tri-Council Policy Statement: Ethical Conduct for Research Involving Humans and, the Carleton University Pollcles and Procedures for the Ethical Conduct of Research.

$X$ New clearance

a Renewal of original clearance Original date of clearance:

Date of clearance

Student researcher

Status

Faculty supervisor

Department

Funding status

Title of project

23 November 2010

François Nadeau

M.A. student

Professor Scott Bennett

Department of Political Science

Not funded

Peace Activists, the Media, and Public Attitudes about Canada-U.S.

Defence Relations

Clearance expires: 31 May 2011

All researchers are governed by the following conditions:

Annual Status Report: You are required to submit an Annual Status Report to either renew clearance or close the file. Failure to submit the Annual Status Report will result in the immediate suspension of the project. Funded projects will have accounts suspended until the report is submitted and approved.

Changes to the project: Any changes to the project must be submitted to the Carleton University Research Ethics Board for approval. All changes must be approved prior to the continuance of the research.

Adverse events: Should any participant suffer adversely from their participation in the project you are required to report the matter to the Carleton University Research Ethics Board. You must submit a written record of the event and indicate what steps you have taken to resolve the situation.

Suspension or termination of clearance: Fallure to conduct the research in accordance with the principles of the Tri-Coundl Policy Statement; Ethical Conduct for Research Involving Humans and the Carieton University Policies and Procedures for the Ethical Conduct of Research may result in the suspension or termination of the research project.

¿Létle J.Màtbonald-Hick's

Research Ethics Board Coordinator

For the Chair of the Carleton University Research Ethics Board

Prof. Antonio Gualtieri 


\section{Appendix F: Regression Output from SPSS}

\section{Hypothesis 1a}

\begin{tabular}{|l|r|r|r|r|r|}
\hline & & & \multicolumn{1}{c|}{ Model Summary } \\
\hline Model & $\mathrm{R}$ & $\mathrm{R}$ Squared R & \multicolumn{1}{c|}{$\begin{array}{c}\text { Std. Error of the } \\
\text { Square }\end{array}$} & \multicolumn{1}{c|}{ Estimate } & Durbin-Watson \\
\hline 1 & $.748^{\mathrm{a}}$ & .559 & .547 & .9748 & 1.956 \\
\hline
\end{tabular}

a. Predictors: (Constant), aq9 - Importance of Space Weaponization Issue, Experimental Group

b. Dependent Variable: bq5 - Importance of Space Weaponization Issue

\begin{tabular}{|c|c|c|c|c|c|c|}
\hline \multicolumn{7}{|c|}{ ANOVA $^{b}$} \\
\hline & & Sum of Squares & $d f$ & Mean Square & $F$ & Sig. \\
\hline \multirow[t]{3}{*}{1} & Regression & 91.579 & 2 & 45.790 & 48.188 & $.000^{a}$ \\
\hline & Residual & 72.218 & 76 & .950 & & \\
\hline & Total & 163.797 & 78 & & & \\
\hline
\end{tabular}

a. Predictors: (Constant), aq9 - Importance of Space Weaponization Issue, Experimental Group

b. Dependent Variable: bq5 - Importance of Space Weaponization Issue

\section{Coefficients $^{\mathrm{a}}$}

\begin{tabular}{|c|c|c|c|c|c|c|c|c|c|}
\hline \multirow[b]{2}{*}{ Model } & \multicolumn{2}{|c|}{$\begin{array}{c}\text { Unstandardized } \\
\text { Coefficients }\end{array}$} & \multirow{2}{*}{$\begin{array}{c}\text { Standardized } \\
\text { Coefficients } \\
\text { Beta }\end{array}$} & \multirow[b]{2}{*}{$t$} & \multirow[b]{2}{*}{ Sig. } & \multicolumn{2}{|c|}{$\begin{array}{c}95.0 \% \\
\text { Confidence } \\
\text { Interval for B }\end{array}$} & \multicolumn{2}{|c|}{$\begin{array}{l}\text { Collinearity } \\
\text { Statistics }\end{array}$} \\
\hline & B & $\begin{array}{l}\text { Std. } \\
\text { Error }\end{array}$ & & & & $\begin{array}{l}\text { Lower } \\
\text { Bound }\end{array}$ & $\begin{array}{l}\text { Upper } \\
\text { Bound }\end{array}$ & Tolerance & VIF \\
\hline 1 (Constant) & 1.989 & .339 & & 5.862 & .000 & 1.313 & 2.665 & & \\
\hline Film & 1.169 & .221 & .406 & 5.289 & .000 & .729 & 1.609 & .986 & 1.014 \\
\hline SpaceWeapons & .549 & .072 & .583 & 7.596 & .000 & .405 & .693 & .986 & 1.014 \\
\hline
\end{tabular}

a. Dependent Variable: bq5 - Importance of Space

Weaponization Issue 


\section{Hypothesis 1b}

Model Summary

\begin{tabular}{|l|r|r|r|r|r|}
\hline Model & $\mathrm{R}$ & $\mathrm{R}$ Square & \multicolumn{1}{c|}{$\begin{array}{c}\text { Adjusted R } \\
\text { Square }\end{array}$} & $\begin{array}{c}\text { Std. Error of the } \\
\text { Estimate }\end{array}$ & Durbin-Watson \\
\hline 1 & $.761^{\mathrm{a}}$ & .579 & .568 & .9224 & 2.016 \\
\hline
\end{tabular}

a. Predictors: (Constant), aq8 - Importance of Nuclear Proliferation Issue, Experimental Group

b. Dependent Variable: bq4 - Importance of Nuclear Proliferation Issue

ANOVA $^{b}$

\begin{tabular}{|c|c|c|c|c|c|c|}
\hline \multicolumn{2}{|c|}{ Model } & Sum of Squares & $d f$ & Mean Square & $F$ & Sig. \\
\hline \multirow[t]{3}{*}{1} & Regression & 87.674 & 2 & 43.837 & 51.522 & $.000^{a}$ \\
\hline & Residual & 63.813 & 75 & .851 & & \\
\hline & Total & 151.487 & 77 & & & \\
\hline
\end{tabular}

a. Predictors: (Constant), aq8 - Importance of Nuclear Proliferation Issue, Experimental Group

b. Dependent Variable: bq4 - Importance of Nuclear Proliferation Issue

\section{Coefficients $^{a}$}

\begin{tabular}{|c|c|c|c|c|c|c|c|c|c|}
\hline \multirow[b]{2}{*}{ Model } & \multicolumn{2}{|c|}{$\begin{array}{l}\text { Unstandardized } \\
\text { Coefficients }\end{array}$} & $\begin{array}{l}\text { Standardized } \\
\text { Coefficients }\end{array}$ & \multirow[b]{2}{*}{$t$} & \multirow[b]{2}{*}{ Sig. } & \multicolumn{2}{|c|}{$\begin{array}{c}95.0 \% \text { Confidence } \\
\text { Interval for } \mathrm{B}\end{array}$} & \multicolumn{2}{|c|}{$\begin{array}{l}\text { Collinearity } \\
\text { Statistics }\end{array}$} \\
\hline & B & Std. Error & Beta & & & $\begin{array}{l}\text { Lower } \\
\text { Bound }\end{array}$ & $\begin{array}{l}\text { Upper } \\
\text { Bound }\end{array}$ & Tolerance & VIF \\
\hline 1 (Constant) & 1.331 & .426 & & 3.120 & .003 & .481 & 2.180 & & \\
\hline Film & .768 & .209 & .276 & 3.674 & .000 & .352 & 1.185 & .999 & 1.001 \\
\hline NukeProliferation & .702 & .073 & .719 & 9.593 & .000 & .556 & .848 & .999 & 1.001 \\
\hline
\end{tabular}

a. Dependent Variable: bq4 - Importance of Nuclear Proliferation Issue 


\section{Hypothesis 2a}

Model Summary

\begin{tabular}{|l|r|r|r|r|r|}
\hline Model & $\mathrm{R}$ & $\mathrm{R}$ Square & \multicolumn{1}{c|}{$\begin{array}{c}\text { Adjusted R } \\
\text { Square }\end{array}$} & $\begin{array}{c}\text { Std. Error of the } \\
\text { Estimate }\end{array}$ & Durbin-Watson \\
\hline 1 & $.688^{\mathrm{a}}$ & .474 & .460 & 1.2339 & 2.144 \\
\hline
\end{tabular}

a. Predictors: (Constant), aq10a - Importance of Satellites to Personal Way of Life,

Experimental Group

b. Dependent Variable: bq6a - Importance of Satellites to Personal Way of Life

ANOVA $^{\mathrm{b}}$

\begin{tabular}{|l|r|r|r|r|r|}
\hline Model & Sum of Squares & df & Mean Square & F & Sig. \\
\hline 1 & 105.508 & 2 & 52.754 & 34.647 & $.000^{\mathrm{a}}$ \\
Regression & 117.242 & 77 & 1.523 & & \\
Residual & 222.750 & 79 & & & \\
Total & & & & \\
\hline
\end{tabular}

a. Predictors: (Constant), aq10a - Importance of Satellites to Personal Way of Life, Experimental Group

b. Dependent Variable: bq6a - Importance of Satellites to Personal Way of Life

\begin{tabular}{|c|c|c|c|c|c|c|c|c|c|}
\hline \multirow[b]{3}{*}{ Model } & \multicolumn{7}{|c|}{ Coefficients $^{a}$} & & \\
\hline & \multicolumn{2}{|c|}{$\begin{array}{c}\text { Unstandardized } \\
\text { Coefficients }\end{array}$} & $\begin{array}{l}\text { Standardized } \\
\text { Coefficients }\end{array}$ & \multirow[b]{2}{*}{$t$} & \multirow[b]{2}{*}{ Sig. } & \multicolumn{2}{|c|}{$\begin{array}{c}95.0 \% \\
\text { Confidence } \\
\text { Interval for B }\end{array}$} & \multicolumn{2}{|c|}{$\begin{array}{c}\text { Collinearity } \\
\text { Statistics }\end{array}$} \\
\hline & $\mathrm{B}$ & Std. Error & Beta & & & $\begin{array}{l}\text { Lower } \\
\text { Bound }\end{array}$ & $\begin{array}{l}\text { Upper } \\
\text { Bound }\end{array}$ & Tolerance & VIF \\
\hline 1 (Constant) & 1.416 & .496 & & 2.856 & .006 & .429 & 2.403 & & \\
\hline Film & .985 & .278 & .295 & 3.544 & .001 & .432 & 1.539 & .987 & 1.013 \\
\hline SatPersonal & .680 & .086 & .656 & 7.882 & .000 & .508 & .851 & .987 & 1.013 \\
\hline
\end{tabular}

a. Dependent Variable: bq6a - Importance of Satellites to Personal Way of Life 


\section{Hypothesis 2b}

Model Summary ${ }^{b}$

\begin{tabular}{|l|r|r|r|r|r|}
\hline Model & $\mathrm{R}$ & $\mathrm{R}$ Square & \multicolumn{1}{c|}{$\begin{array}{c}\text { Adjusted R } \\
\text { Square }\end{array}$} & $\begin{array}{c}\text { Std. Error of the } \\
\text { Estimate }\end{array}$ & Durbin-Watson \\
\hline 1 & $.661^{\mathrm{a}}$ & .437 & .423 & 1.1962 & 2.107 \\
\hline
\end{tabular}

a. Predictors: (Constant), aq10b - Importance of Satellites to American Way of Life,

Experimental Group

b. Dependent Variable: bq6b - Importance of Satellites to American Way of Life

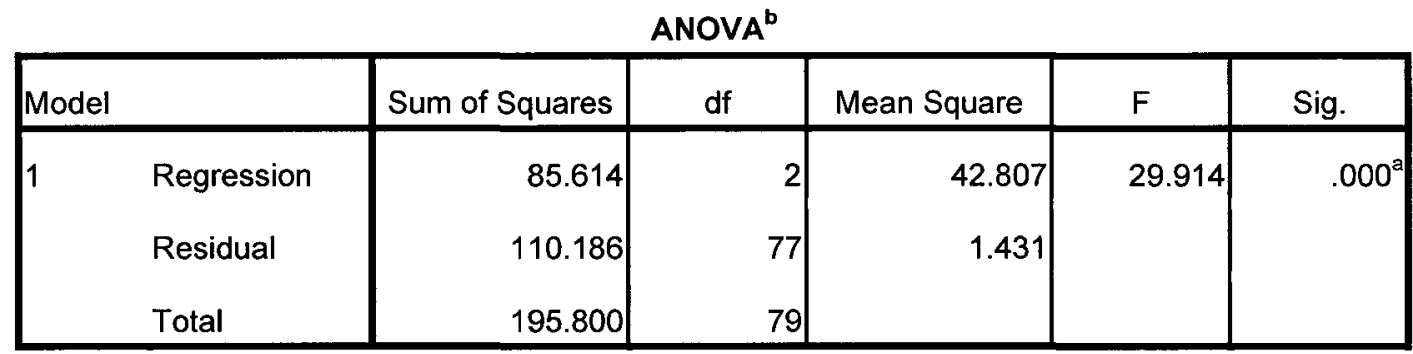

a. Predictors: (Constant), aq10b - Importance of Satellites to American Way of Life, Experimental Group

b. Dependent Variable: bq6b - Importance of Satellites to American Way of Life

\begin{tabular}{|c|c|c|c|c|c|c|c|c|c|}
\hline \multirow[b]{3}{*}{ Model } & \multicolumn{7}{|c|}{ Coefficients $^{\mathrm{a}}$} & & \\
\hline & \multicolumn{2}{|c|}{$\begin{array}{l}\text { Unstandardized } \\
\text { Coefficients }\end{array}$} & $\begin{array}{l}\text { Standardized } \\
\text { Coefficients }\end{array}$ & \multirow[b]{2}{*}{$t$} & \multirow[b]{2}{*}{ Sig. } & \multicolumn{2}{|c|}{$\begin{array}{c}95.0 \% \text { Confidence } \\
\text { Interval for B }\end{array}$} & \multicolumn{2}{|c|}{$\begin{array}{l}\text { Collinearity } \\
\text { Statistics }\end{array}$} \\
\hline & $\mathrm{B}$ & Std. Error & Beta & & & $\begin{array}{l}\text { Lower } \\
\text { Bound }\end{array}$ & $\begin{array}{l}\text { Upper } \\
\text { Bound }\end{array}$ & Tolerance & VIF \\
\hline 1 (Constant) & 1.808 & .491 & & 3.684 & .000 & .831 & 2.786 & & \\
\hline Film & .556 & .269 & .177 & 2.070 & .042 & .021 & 1.091 & .994 & 1.006 \\
\hline SatAmericans & .642 & .085 & .651 & 7.592 & .000 & .473 & .810 & .994 & 1.006 \\
\hline
\end{tabular}

a. Dependent Variable: bq6b - Importance of Satellites to American Way of Life 


\section{Hypothesis 2c}

Model Summary ${ }^{b}$

\begin{tabular}{|l|r|r|r|r|r|}
\hline Model & $\mathrm{R}$ & $\mathrm{R}$ Square & \multicolumn{1}{c|}{$\begin{array}{c}\text { Adjusted R } \\
\text { Square }\end{array}$} & $\begin{array}{c}\text { Std. Error of the } \\
\text { Estimate }\end{array}$ & Durbin-Watson \\
\hline 1 & $.778^{\mathrm{a}}$ & .605 & .595 & .8326 & 2.339 \\
\hline
\end{tabular}

a. Predictors: (Constant), aq10c - Importance of Satellites to North American Defence, Experimental Group

b. Dependent Variable: bq6c - Importance of Satellites to North American Defence

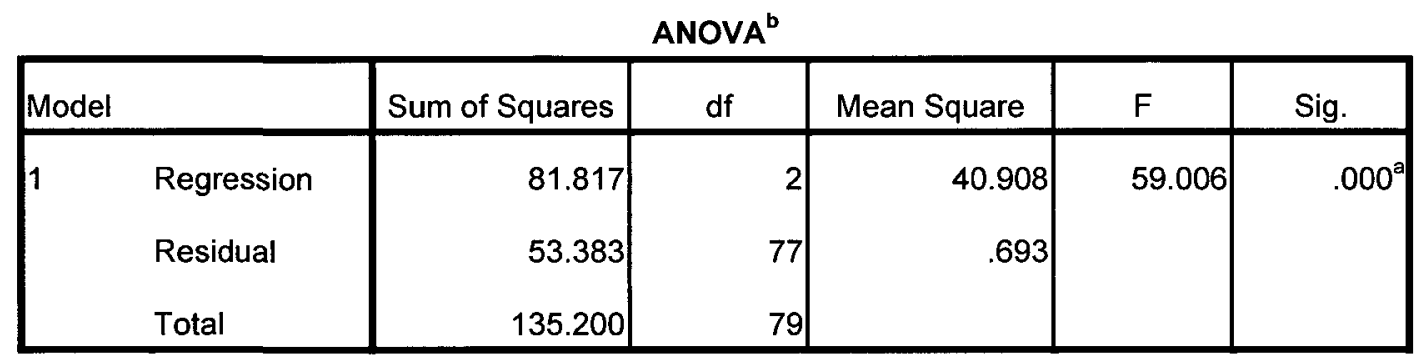

a. Predictors: (Constant), aq10c - Importance of Satellites to North American Defence, Experimental Group

b. Dependent Variable: bq6c - Importance of Satellites to North American Defence

\begin{tabular}{|c|c|c|c|c|c|c|c|c|c|}
\hline \multirow[b]{3}{*}{ Model } & \multicolumn{7}{|c|}{ Coefficients $^{\mathrm{a}}$} & & \\
\hline & \multicolumn{2}{|c|}{$\begin{array}{l}\text { Unstandardized } \\
\text { Coefficients }\end{array}$} & $\begin{array}{l}\text { Standardized } \\
\text { Coefficients }\end{array}$ & \multirow[b]{2}{*}{$t$} & \multirow[b]{2}{*}{ Sig. } & \multicolumn{2}{|c|}{$\begin{array}{c}95.0 \% \text { Confidence } \\
\text { Interval for B }\end{array}$} & \multicolumn{2}{|c|}{$\begin{array}{l}\text { Collinearity } \\
\text { Statistics }\end{array}$} \\
\hline & $\mathrm{B}$ & Std. Error & Beta & & & $\begin{array}{l}\text { Lower } \\
\text { Bound }\end{array}$ & $\begin{array}{l}\text { Upper } \\
\text { Bound }\end{array}$ & Tolerance & VIF \\
\hline 1 (Constant) & 1.021 & .426 & & 2.399 & .019 & .173 & 1.869 & & \\
\hline Film & .207 & .188 & .079 & 1.099 & .275 & -.168 & .581 & .983 & 1.017 \\
\hline SatDefence & .771 & .071 & .784 & 10.859 & .000 & .630 & .913 & .983 & 1.017 \\
\hline
\end{tabular}

a. Dependent Variable: bq6c - Importance of Satellites to North American Defence 


\section{Hypothesis 2d}

\begin{tabular}{|c|c|c|c|c|c|}
\hline \multicolumn{6}{|c|}{ Model Summary ${ }^{b}$} \\
\hline Model & $\mathrm{R}$ & R Square & $\begin{array}{l}\text { Adjusted R } \\
\text { Square }\end{array}$ & $\begin{array}{c}\text { Std. Error of the } \\
\text { Estimate }\end{array}$ & Durbin-Watson \\
\hline 1 & $.655^{\mathrm{a}}$ & .429 & .414 & 1.0771 & 2.139 \\
\hline
\end{tabular}

a. Predictors: (Constant), aq10d - Importance of Satellites to American Military Operations Abroad, Experimental Group

b. Dependent Variable: bq6d - Importance of Satellites to American Military Operations Abroad

\begin{tabular}{|rr|r|r|r|r|r|}
\hline \multicolumn{1}{|c|}{ ANOVA $^{\mathrm{b}}$} & & \\
\hline 1 & Sum of Squares & df & Mean Square & $\mathrm{F}$ & Sig. \\
\hline & Regression & 66.254 & 2 & 33.127 & 28.552 & $.000^{\mathrm{a}}$ \\
& Residual & 88.177 & 76 & 1.160 & & \\
& & & & & \\
\hline
\end{tabular}

a. Predictors: (Constant), aq10d - Importance of Satellites to American Military Operations Abroad, Experimental Group

b. Dependent Variable: bq6d - Importance of Satellites to American Military Operations Abroad

\begin{tabular}{|c|c|c|c|c|c|c|c|c|c|}
\hline \multirow[b]{3}{*}{ Model } & \multicolumn{9}{|c|}{ Coefficients $^{a}$} \\
\hline & \multicolumn{2}{|c|}{$\begin{array}{c}\text { Unstandardized } \\
\text { Coefficients }\end{array}$} & \multirow{2}{*}{$\begin{array}{c}\text { Standardized } \\
\text { Coefficients } \\
\text { Beta }\end{array}$} & \multirow[b]{2}{*}{$\mathrm{t}$} & \multirow[b]{2}{*}{ Sig. } & \multicolumn{2}{|c|}{$\begin{array}{c}95.0 \% \\
\text { Confidence } \\
\text { Interval for B }\end{array}$} & \multicolumn{2}{|c|}{$\begin{array}{c}\text { Collinearity } \\
\text { Statistics }\end{array}$} \\
\hline & $\mathrm{B}$ & $\begin{array}{l}\text { Std. } \\
\text { Error }\end{array}$ & & & & $\begin{array}{l}\text { Lower } \\
\text { Bound }\end{array}$ & $\begin{array}{l}\text { Upper } \\
\text { Bound }\end{array}$ & Tolerance & VIF \\
\hline 1 (Constant) & 2.360 & .483 & & 4.884 & .000 & 1.397 & 3.322 & & \\
\hline Film & -.046 & .243 & -.016 & -.188 & .851 & -.529 & .438 & 1.000 & 1.000 \\
\hline SatOperations & .599 & .079 & .655 & 7.555 & .000 & .441 & .757 & 1.000 & 1.000 \\
\hline
\end{tabular}

a. Dependent Variable: bq6d - Importance of Satellites to American Military Operations Abroad 


\section{Hypothesis 3}

\begin{tabular}{|c|c|c|c|c|c|c|c|c|c|c|}
\hline \multicolumn{11}{|c|}{ Model Summary } \\
\hline \multirow[b]{2}{*}{ Model } & \multirow[b]{2}{*}{$\mathrm{R}$} & \multirow[b]{2}{*}{$\begin{array}{c}\mathrm{R} \\
\text { Square }\end{array}$} & \multirow[b]{2}{*}{$\begin{array}{c}\text { Adjusted R } \\
\text { Square }\end{array}$} & \multirow[b]{2}{*}{$\begin{array}{c}\text { Std. Error of the } \\
\text { Estimate }\end{array}$} & \multicolumn{5}{|c|}{ Change Statistics } & \multirow[b]{2}{*}{$\begin{array}{l}\text { Durbin- } \\
\text { Watson }\end{array}$} \\
\hline & & & & & $\begin{array}{l}\text { R Square } \\
\text { Change }\end{array}$ & $\begin{array}{c}\mathrm{F} \\
\text { Change }\end{array}$ & df1 & df2 & $\begin{array}{c}\text { Sig. F } \\
\text { Change }\end{array}$ & \\
\hline 1 & $.419^{a}$ & .176 & .165 & .914 & .176 & 16.398 & 1 & 77 & .000 & \\
\hline 2 & $.946^{b}$ & .895 & .890 & .331 & .719 & 256.104 & 2 & 75 & .000 & \\
\hline 3 & $.948^{\mathrm{C}}$ & .898 & .893 & .328 & .003 & 2.538 & 1 & 74 & .115 & 2.222 \\
\hline
\end{tabular}

a. Predictors: (Constant), ZSPACEBAN2

b. Predictors: (Constant), ZSPACEBAN2, ZFILM, ZUSOBAMA

c. Predictors: (Constant), ZSPACEBAN2, ZFILM, ZUSOBAMA, ZFILMxZSPACEBAN2

d. Dependent Variable: ZUSOBAMA2

\begin{tabular}{|c|c|c|c|c|c|c|}
\hline \multicolumn{7}{|c|}{ ANOVA $^{d}$} \\
\hline \multicolumn{2}{|c|}{ Model } & Sum of Squares & df & Mean Square & $\mathbf{F}$ & Sig. \\
\hline 1 & Regression & 13.694 & 1 & 13.694 & 16.398 & $.000^{a}$ \\
\hline & Residual & 64.306 & 77 & .835 & & \\
\hline & Total & 78.000 & 78 & & & \\
\hline 2 & Regression & 69.787 & 3 & 23.262 & 212.419 & $.000^{b}$ \\
\hline & Residual & 8.213 & 75 & .110 & & \\
\hline & Total & 78.000 & 78 & & & \\
\hline 3 & Regression & 70.059 & 4 & 17.515 & 163.215 & $.000^{\mathrm{c}}$ \\
\hline & Residual & 7.941 & 74 & .107 & & \\
\hline & Total & 78.000 & 78 & & & \\
\hline
\end{tabular}
a. Predictors: (Constant), ZSPACEBAN2
b. Predictors: (Constant), ZSPACEBAN2, ZFILM, ZUSOBAMA
c. Predictors: (Constant), ZSPACEBAN2, ZFILM, ZUSOBAMA, ZFILMxZSPACEBAN2
d. Dependent Variable: ZUSOBAMA2 
Coefficients $^{a}$

\begin{tabular}{|c|c|c|c|c|c|c|c|}
\hline \multirow[b]{2}{*}{ Model } & \multicolumn{2}{|c|}{$\begin{array}{c}\text { Unstandardized } \\
\text { Coefficients } \\
\end{array}$} & $\begin{array}{l}\text { Standardized } \\
\text { Coefficients }\end{array}$ & \multirow[b]{2}{*}{$t$} & \multirow[b]{2}{*}{ Sig. } & \multicolumn{2}{|c|}{$\begin{array}{c}95.0 \% \text { Confidence } \\
\text { Interval for B }\end{array}$} \\
\hline & B & Std. Error & Beta & & & $\begin{array}{l}\text { Lower } \\
\text { Bound }\end{array}$ & $\begin{array}{l}\text { Upper } \\
\text { Bound }\end{array}$ \\
\hline $\begin{array}{l}1 \text { (Constant) } \\
\text { ZSPACEBAN2 }\end{array}$ & $\begin{array}{r}6.423 \mathrm{E}-16 \\
.419 \\
\end{array}$ & $\begin{array}{r}.103 \\
.103 \\
\end{array}$ & .419 & $\begin{array}{r}.000 \\
4.049 \\
\end{array}$ & $\begin{array}{r}1.000 \\
000 \\
.000 \\
\end{array}$ & $\begin{array}{r}.205 \\
.213 \\
\end{array}$ & $\begin{array}{l}.205 \\
.625 \\
\end{array}$ \\
\hline $\begin{array}{l}2 \text { (Constant) } \\
\text { ZSPACEBAN2 } \\
\text { ZFILM } \\
\text { ZUSOBAMA }\end{array}$ & $\begin{array}{r}.008 \\
.099 \\
-.010 \\
.902 \\
\end{array}$ & $\begin{array}{l}.037 \\
.041 \\
.038 \\
.040\end{array}$ & $\begin{array}{r}.099 \\
-.010 \\
.906\end{array}$ & $\begin{array}{r}.204 \\
2.421 \\
-.265 \\
22.630\end{array}$ & $\begin{array}{l}.839 \\
.018 \\
.792 \\
.000 \\
\end{array}$ & $\begin{array}{r}-.067 \\
.017 \\
-.086 \\
.823\end{array}$ & $\begin{array}{l}.082 \\
.180 \\
.066 \\
.982\end{array}$ \\
\hline $\begin{array}{l}3 \text { (Constant) } \\
\text { ZSPACEBAN2 } \\
\text { ZFILM } \\
\text { ZUSOBAMA } \\
\text { ZFILMxZSPACEBAN2 }\end{array}$ & $\begin{array}{r}.020 \\
.078 \\
.012 \\
.911 \\
.063\end{array}$ & $\begin{array}{l}.038 \\
.042 \\
.038 \\
.040 \\
.039\end{array}$ & $\begin{array}{r}.078 \\
-.012 \\
.915\end{array}$ & $\begin{array}{r}.527 \\
1.840 \\
-.330 \\
22.860 \\
1.593\end{array}$ & $\begin{array}{l}.600 \\
.070 \\
.742 \\
.000 \\
.115\end{array}$ & $\begin{array}{r}-.055 \\
-.006 \\
-.088 \\
.832 \\
-.016\end{array}$ & $\begin{array}{l}.095 \\
.162 \\
.063 \\
.991\end{array}$ \\
\hline
\end{tabular}

a. Dependent Variable: ZUSOBAMA2 


\section{Hypothesis 4a}

\begin{tabular}{|c|c|c|c|c|c|c|c|c|c|c|}
\hline \multirow[b]{3}{*}{ Model } & \multicolumn{9}{|c|}{ Model Summary ${ }^{d}$} & \multirow[b]{3}{*}{$\begin{array}{l}\text { Durbin- } \\
\text { Watson }\end{array}$} \\
\hline & \multirow[b]{2}{*}{$\mathrm{R}$} & \multirow[b]{2}{*}{$\begin{array}{c}\mathrm{R} \\
\text { Square }\end{array}$} & \multirow[b]{2}{*}{$\begin{array}{c}\text { Adjusted R } \\
\text { Square }\end{array}$} & \multirow[b]{2}{*}{$\begin{array}{l}\text { Std. Error of } \\
\text { the Estimate }\end{array}$} & \multicolumn{5}{|c|}{ Change Statistics } & \\
\hline & & & & & $\begin{array}{c}\text { R Square } \\
\text { Change }\end{array}$ & $\begin{array}{c}F \\
\text { Change }\end{array}$ & df1 & $\mathrm{df} 2$ & $\begin{array}{c}\text { Sig. F } \\
\text { Change }\end{array}$ & \\
\hline 1 & $.434^{\mathrm{a}}$ & .188 & .156 & .920 & .188 & 5.729 & 3 & 74 & .001 & \\
\hline 2 & $.737^{b}$ & .544 & .512 & .699 & .355 & 28.053 & 2 & 72 & .000 & \\
\hline 3 & $.754^{\circ}$ & .569 & .519 & .695 & .025 & 1.316 & 3 & 69 & .276 & 1.812 \\
\hline
\end{tabular}

a. Predictors: (Constant), ZANTI_AMERICANISM, ZINTERNATIONALISM, ZIDEOLOGY

b. Predictors: (Constant), ZANTI_AMERICANISM, ZINTERNATIONALISM, ZIDEOLOGY, ZFILM, ZMISSILEDEF3

c. Predictors: (Constant), ZANTI_AMERICANISM, ZINTERNATIONALISM, ZIDEOLOGY, ZFILM, ZMISSILEDEF3, ZFILMXZINTERNATIONALISM, ZFILMXZANTI_AMERICANISM, ZFILMxZIDEOLOGY

d. Dependent Variable: ZMISSILEDEF4

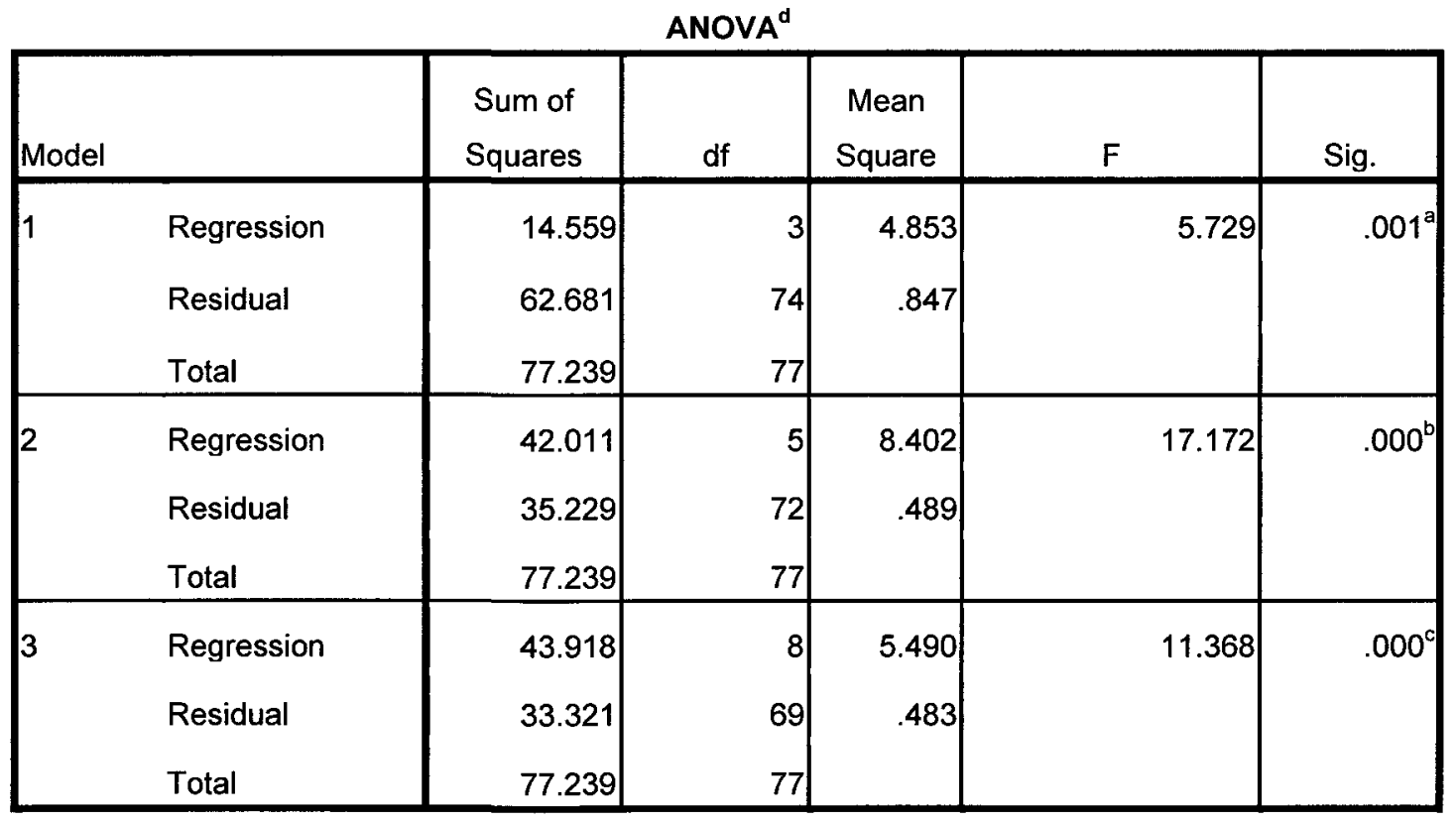

a. Predictors: (Constant), ZANTI_AMERICANISM, ZINTERNATIONALISM, ZIDEOLOGY

b. Predictors: (Constant), ZANTI_AMERICANISM, ZINTERNATIONALISM, ZIDEOLOGY, ZFILM, ZMISSILEDEF3

c. Predictors: (Constant), ZANTI_AMERICANISM, ZINTERNATIONALISM, ZIDEOLOGY, ZFILM, ZMISSILEDEF3, ZFILMXZINTERNATIONALISM, ZFILMXZANTI_AMERICANISM,

ZFILMXZIDEOLOGY 


\begin{tabular}{|c|c|c|c|c|c|c|c|c|c|c|}
\hline \multicolumn{11}{|c|}{ Model Summary ${ }^{d}$} \\
\hline \multirow[b]{2}{*}{ Model } & \multirow[b]{2}{*}{$\mathrm{R}$} & \multirow[b]{2}{*}{$\begin{array}{c}\mathrm{R} \\
\text { Square }\end{array}$} & \multirow[b]{2}{*}{$\begin{array}{c}\text { Adjusted R } \\
\text { Square }\end{array}$} & \multirow[b]{2}{*}{$\begin{array}{l}\text { Std. Error of } \\
\text { the Estimate }\end{array}$} & \multicolumn{5}{|c|}{ Change Statistics } & \multirow[b]{2}{*}{$\begin{array}{l}\text { Durbin- } \\
\text { Watson }\end{array}$} \\
\hline & & & & & $\begin{array}{c}\text { R Square } \\
\text { Change }\end{array}$ & $\begin{array}{c}\mathrm{F} \\
\text { Change }\end{array}$ & df1 & $\mathrm{df2}$ & $\begin{array}{c}\text { Sig. F } \\
\text { Change }\end{array}$ & \\
\hline 1 & $.434^{a}$ & .188 & .156 & .920 & .188 & 5.729 & 3 & 74 & .001 & \\
\hline 2 & $.737^{b}$ & .544 & .512 & .699 & .355 & 28.053 & 2 & 72 & .000 & \\
\hline 3 & $.754^{c}$ & .569 & .519 & .695 & .025 & 1.316 & 3 & 69 & .276 & 1.812 \\
\hline
\end{tabular}

a. Predictors: (Constant), ZANTI_AMERICANISM, ZINTERNATIONALISM, ZIDEOLOGY

b. Predictors: (Constant), ZANTI_AMERICANISM, ZINTERNATIONALISM, ZIDEOLOGY, ZFILM, ZMISSILEDEF3

c. Predictors: (Constant), ZANTI_AMERICANISM, ZINTERNATIONALISM, ZIDEOLOGY, ZFILM, ZMISSILEDEF3, ZFILMxZINTERNATIONALISM, ZFILMxZANTI_AMERICANISM, ZFILMxZIDEOLOGY

d. Dependent Variable: ZMISSILEDEF4 


\section{Coefficients $^{a}$}

\begin{tabular}{|c|c|c|c|c|c|c|c|}
\hline \multirow[b]{2}{*}{ Model } & \multicolumn{2}{|c|}{$\begin{array}{c}\text { Unstandardized } \\
\text { Coefficients } \\
\end{array}$} & \multirow{2}{*}{ Beta } & \multirow[b]{2}{*}{$t$} & \multirow[b]{2}{*}{ Sig. } & \multicolumn{2}{|c|}{$\begin{array}{c}95.0 \% \text { Confidence Interval } \\
\text { for B } \\
\end{array}$} \\
\hline & B & Std. Error & & & & Lower Bound & Upper Bound \\
\hline 1 (Constant) & .011 & .104 & & .103 & .918 & -.197 & .218 \\
\hline ZIDEOLOGY & -.341 & .113 & & & .004 & -.567 & -.116 \\
\hline ZINTERNATIONALISM & -.023 & .111 & & -.203 & .840 & -.245 & .199 \\
\hline ZANTI_AMERICANISM & -.164 & .112 & $\begin{array}{r}- \\
.165\end{array}$ & 1.464 & .148 & -.388 & .059 \\
\hline 2 (Constant) & .009 & .079 & & .114 & .909 & -.149 & .167 \\
\hline ZIDEOLOGY & -.135 & .091 & & & .142 & -.316 & .046 \\
\hline ZINTERNATIONALISM & -.010 & .085 & - & -.112 & .911 & -.179 & .160 \\
\hline ZANTI_AMERICANISM & -.006 & .088 & - & -.066 & .948 & -.181 & .169 \\
\hline ZFILM & .212 & .080 & .211 & 2.636 & .010 & .052 & .372 \\
\hline ZMISSILEDEF3 & .645 & .090 & .649 & 7.153 & .000 & .465 & .824 \\
\hline 3 (Constant) & .002 & .079 & & .031 & .975 & -.155 & .160 \\
\hline ZIDEOLOGY & -.173 & .093 & & & .067 & -.358 & .013 \\
\hline ZINTERNATIONALISM & .026 & .087 & .026 & .304 & .762 & -.147 & .200 \\
\hline ZANTI_AMERICANISM & .032 & .092 & .033 & .350 & .727 & -.152 & .216 \\
\hline ZFILM & .213 & .080 & .212 & 2.663 & .010 & .053 & .372 \\
\hline ZMISSILEDEF3 & .684 & .093 & .688 & 7.316 & .000 & .497 & .870 \\
\hline ZFILMXZIDEOLOGY & -.165 & .094 & & & .083 & -.352 & .022 \\
\hline ZFILMxZINTERNATIONALISM & .119 & .088 & .118 & 1.351 & .181 & -.057 & .294 \\
\hline ZFILMXZANTI_AMERICANISM & .050 & .092 & .050 & .548 & .586 & -.133 & .234 \\
\hline
\end{tabular}

a. Dependent Variable: ZMISSILEDEF4 


\section{Hypothesis $4 b$}

\begin{tabular}{|c|c|c|c|c|c|c|c|c|c|c|}
\hline \multirow[b]{3}{*}{ Model } & \multicolumn{9}{|c|}{ Model Summary ${ }^{d}$} & \multirow[b]{3}{*}{$\begin{array}{l}\text { Durbin- } \\
\text { Watson }\end{array}$} \\
\hline & \multirow[b]{2}{*}{$\mathrm{R}$} & \multirow[b]{2}{*}{$\begin{array}{c}\mathrm{R} \\
\text { Square }\end{array}$} & \multirow[b]{2}{*}{$\begin{array}{c}\text { Adjusted R } \\
\text { Square }\end{array}$} & \multirow{2}{*}{$\begin{array}{c}\text { Std. Error } \\
\text { of the } \\
\text { Estimate }\end{array}$} & \multicolumn{5}{|c|}{ Change Statistics } & \\
\hline & & & & & $\begin{array}{c}\text { R Square } \\
\text { Change }\end{array}$ & $\begin{array}{c}F \\
\text { Change }\end{array}$ & df1 & $\mathrm{df2}$ & $\begin{array}{c}\text { Sig. F } \\
\text { Change }\end{array}$ & \\
\hline 1 & $.476^{a}$ & .227 & .196 & .885 & .227 & 7.325 & 3 & 75 & .000 & \\
\hline 2 & $.703^{b}$ & .494 & .460 & .725 & .268 & 19.312 & 2 & 73 & .000 & \\
\hline 3 & $.711^{\mathrm{C}}$ & .506 & .449 & .732 & .012 & .553 & 3 & 70 & .648 & 1.835 \\
\hline
\end{tabular}

a. Predictors: (Constant), ZANTI_AMERICANISM, ZINTERNATIONALISM, ZIDEOLOGY

b. Predictors: (Constant), ZANTI_AMERICANISM, ZINTERNATIONALISM, ZIDEOLOGY, ZFILM, ZSATTRACKING3

c. Predictors: (Constant), ZANTI_AMERICANISM, ZINTERNATIONALISM, ZIDEOLOGY, ZFILM, ZSATTRACKING3, ZFILMXZINTERNATIONALISM, ZFILMxZIDEOLOGY, ZFILMxZANTI_AMERICANISM

d. Dependent Variable: ZSATTRACKING4

\begin{tabular}{|ll|r|r|r|r|r|}
\hline Model & & Sum of Squares & df & Mean Square & F & \multicolumn{1}{c|}{ Sig. } \\
\hline 1 & Regression & 17.192 & 3 & 5.731 & 7.325 & $.000^{\mathrm{a}}$ \\
& Residual & 58.678 & 75 & .782 & & \\
& Total & 75.870 & 78 & & & \\
\hline $2 \quad 37.496$ & 5 & 7.499 & 14.266 & $.000^{\mathrm{b}}$ \\
& Regression & 38.374 & 73 & .526 & & \\
& Residual & 75.870 & 78 & & & \\
& Total & 38.384 & 8 & 4.798 & 8.959 & $.000^{\mathrm{c}}$ \\
\hline 3 & 37.487 & 70 & .536 & & \\
& Regression & 75.870 & 78 & & & \\
\hline
\end{tabular}

a. Predictors: (Constant), ZANTI_AMERICANISM, ZINTERNATIONALISM, ZIDEOLOGY

b. Predictors: (Constant), ZANTI_AMERICANISM, ZINTERNATIONALISM, ZIDEOLOGY, ZFILM, ZSATTRACKING3

c. Predictors: (Constant), ZANTI_AMERICANISM, ZINTERNATIONALISM, ZIDEOLOGY, ZFILM, ZSATTRACKING3, ZFILMXZINTERNATIONALISM, ZFILMXZIDEOLOGY,

ZFILMXZANTI_AMERICANISM

d. Dependent Variable: ZSATTRACKING4 
Coefficients $^{a}$

\begin{tabular}{|c|c|c|c|c|c|c|c|}
\hline \multirow[b]{2}{*}{ Model } & \multicolumn{2}{|c|}{$\begin{array}{l}\text { Unstandardized } \\
\text { Coefficients }\end{array}$} & $\begin{array}{l}\text { Standardized } \\
\text { Coefficients }\end{array}$ & \multirow[b]{2}{*}{$t$} & \multirow[b]{2}{*}{ Sig. } & \multicolumn{2}{|c|}{$\begin{array}{c}95.0 \% \text { Confidence } \\
\text { Interval for B }\end{array}$} \\
\hline & B & Std. Error & Beta & & & $\begin{array}{l}\text { Lower } \\
\text { Bound }\end{array}$ & $\begin{array}{l}\text { Upper } \\
\text { Bound }\end{array}$ \\
\hline 1 (Constant) & .025 & .100 & & .255 & .799 & -.173 & .224 \\
\hline ZIDEOLOGY & -.329 & .109 & -.334 & $\begin{array}{r}- \\
3.026\end{array}$ & .003 & -.546 & -.113 \\
\hline ZINTERNATIONALISM & .037 & .107 & .037 & .343 & .733 & -.177 & .250 \\
\hline ZANTI_AMERICANISM & -.260 & .108 & -.264 & 2.414 & .018 & -.475 & -.045 \\
\hline 2 (Constant) & .012 & .082 & & .146 & .884 & -.151 & .175 \\
\hline ZIDEOLOGY & -.149 & .094 & -.151 & $\begin{array}{r}- \\
1.581\end{array}$ & .118 & -.336 & .039 \\
\hline ZINTERNATIONALISM & .033 & .088 & .033 & .374 & .709 & -.143 & .209 \\
\hline ZANTI_AMERICANISM & -.144 & .090 & -.146 & & .116 & -.324 & .036 \\
\hline ZFILM & .059 & .083 & .059 & .707 & .482 & -.107 & .224 \\
\hline ZSATTRACKING3 & .566 & .093 & .565 & 6.073 & .000 & .380 & .751 \\
\hline 3 (Constant) & .002 & .083 & & .024 & .981 & -.163 & .167 \\
\hline ZIDEOLOGY & -.163 & .099 & -.165 & & .105 & -.361 & .035 \\
\hline ZINTERNATIONALISM & .048 & .091 & .048 & .522 & .604 & -.134 & .229 \\
\hline ZANTI_AMERICANISM & -.165 & .096 & -.168 & & .088 & -.356 & .025 \\
\hline ZFILM & .061 & .084 & .062 & .724 & .471 & -.106 & .228 \\
\hline ZSATTRACKING3 & .535 & .098 & .534 & 5.471 & .000 & .340 & .730 \\
\hline ZFILMXZIDEOLOGY & -.005 & .097 & -.005 & -.056 & .955 & -.199 & .188 \\
\hline ZFILMXZINTERNATIONALISM & .107 & .094 & .107 & 1.139 & .259 & -.080 & .293 \\
\hline ZFILMXZANTI_AMERICANISM & -.079 & .097 & -.080 & -.819 & $\mid .415$ & -.273 & .114 \\
\hline
\end{tabular}

a. Dependent Variable: ZSATTRACKING4 


\section{Hypothesis 4c}

\begin{tabular}{|c|c|c|c|c|c|c|c|c|c|c|}
\hline \multirow[b]{3}{*}{ Model } & \multicolumn{9}{|c|}{ Model Summary } & \multirow[b]{3}{*}{$\begin{array}{l}\text { Durbin- } \\
\text { Watson }\end{array}$} \\
\hline & \multirow[b]{2}{*}{$\mathrm{R}$} & \multirow[b]{2}{*}{$\begin{array}{c}\mathrm{R} \\
\text { Square }\end{array}$} & \multirow[b]{2}{*}{$\begin{array}{c}\text { Adjusted R } \\
\text { Square }\end{array}$} & \multirow[b]{2}{*}{$\begin{array}{l}\text { Std. Error of } \\
\text { the Estimate }\end{array}$} & \multicolumn{5}{|c|}{ Change Statistics } & \\
\hline & & & & & $\begin{array}{c}\text { R Square } \\
\text { Change }\end{array}$ & $\begin{array}{c}\mathrm{F} \\
\text { Change }\end{array}$ & df1 & df2 & $\begin{array}{c}\text { Sig. F } \\
\text { Change }\end{array}$ & \\
\hline 1 & $.163^{\mathrm{a}}$ & .026 & -.014 & 1.008 & .026 & .660 & 3 & 73 & .579 & \\
\hline 2 & $.803^{\mathrm{b}}$ & .645 & .620 & .617 & .619 & 61.949 & 2 & 71 & .000 & \\
\hline 3 & $.805^{\mathrm{c}}$ & .648 & .606 & .629 & .002 & .143 & 3 & 68 & .934 & 2.377 \\
\hline
\end{tabular}

a. Predictors: (Constant), ZANTI_AMERICANISM, ZINTERNATIONALISM, ZIDEOLOGY

b. Predictors: (Constant), ZANTI_AMERICANISM, ZINTERNATIONALISM, ZIDEOLOGY, ZFILM, ZDEBTRACKING3

c. Predictors: (Constant), ZANTI_AMERICANISM, ZINTERNATIONALISM, ZIDEOLOGY, ZFILM, ZDEBTRACKING3, ZFILMxZINTERNATIONALISM, ZFILMxZANTI_AMERICANISM, ZFILMxZIDEOLOGY

d. Dependent Variable: ZDEBTRACKING4

\begin{tabular}{|c|c|c|c|c|c|c|}
\hline \multicolumn{7}{|c|}{ ANOVA $^{d}$} \\
\hline \multicolumn{2}{|c|}{ Model } & $\begin{array}{l}\text { Sum of } \\
\text { Squares }\end{array}$ & df & $\begin{array}{l}\text { Mean } \\
\text { Square }\end{array}$ & $F$ & Sig. \\
\hline \multirow[t]{3}{*}{1} & Regression & 2.014 & 3 & .671 & .660 & $.579^{\mathrm{a}}$ \\
\hline & Residual & 74.244 & 73 & 1.017 & & \\
\hline & Total & 76.258 & 76 & & & \\
\hline \multirow[t]{3}{*}{2} & Regression & 49.211 & 5 & 9.842 & 25.837 & $.000^{b}$ \\
\hline & Residual & 27.047 & 71 & .381 & & \\
\hline & Total & 76.258 & 76 & & & \\
\hline \multirow[t]{3}{*}{3} & Regression & 49.380 & 8 & 6.173 & 15.617 & $.000^{\circ}$ \\
\hline & Residual & 26.878 & 68 & .395 & & \\
\hline & Total & 76.258 & 76 & & & \\
\hline
\end{tabular}

a. Predictors: (Constant), ZANTI_AMERICANISM, ZINTERNATIONALISM, ZIDEOLOGY

b. Predictors: (Constant), ZANTI_AMERICANISM, ZINTERNATIONALISM, ZIDEOLOGY, ZFILM, ZDEBTRACKING3

c. Predictors: (Constant), ZANTI_AMERICANISM, ZINTERNATIONALISM, ZIDEOLOGY, ZFILM, ZDEBTRACKING3, ZFILMXZINTERNATIONALISM, ZFILMXZANTI_AMERICANISM, ZFILMXZIDEOLOGY 


\begin{tabular}{|c|c|c|c|c|c|c|c|c|c|c|}
\hline \multicolumn{11}{|c|}{ Model Summary ${ }^{d}$} \\
\hline \multirow[b]{2}{*}{ Model } & \multirow[b]{2}{*}{$\mathrm{R}$} & \multirow[b]{2}{*}{$\begin{array}{c}\mathrm{R} \\
\text { Square }\end{array}$} & \multirow[b]{2}{*}{$\begin{array}{c}\text { Adjusted R } \\
\text { Square }\end{array}$} & \multirow[b]{2}{*}{$\begin{array}{l}\text { Std. Error of } \\
\text { the Estimate }\end{array}$} & \multicolumn{5}{|c|}{ Change Statistics } & \multirow[b]{2}{*}{$\begin{array}{l}\text { Durbin- } \\
\text { Watson }\end{array}$} \\
\hline & & & & & $\begin{array}{c}\text { R Square } \\
\text { Change }\end{array}$ & $\begin{array}{c}\mathrm{F} \\
\text { Change }\end{array}$ & df1 & df2 & $\begin{array}{c}\text { Sig. F } \\
\text { Change }\end{array}$ & \\
\hline 1 & $.163^{a}$ & .026 & -.014 & 1.008 & .026 & .660 & 3 & 73 & .579 & \\
\hline 2 & $.803^{b}$ & .645 & .620 & .617 & .619 & 61.949 & 2 & 71 & .000 & \\
\hline 3 & $.805^{c}$ & .648 & .606 & .629 & .002 & .143 & 3 & 68 & .934 & 2.377 \\
\hline
\end{tabular}

a. Predictors: (Constant), ZANTI_AMERICANISM, ZINTERNATIONALISM, ZIDEOLOGY

b. Predictors: (Constant), ZANTI_AMERICANISM, ZINTERNATIONALISM, ZIDEOLOGY, ZFILM, ZDEBTRACKING3

c. Predictors: (Constant), ZANTI_AMERICANISM, ZINTERNATIONALISM, ZIDEOLOGY, ZFILM, ZDEBTRACKING3, ZFILMXZINTERNATIONALISM, ZFILMXZANTI_AMERICANISM, ZFILMxZIDEOLOGY d. Dependent Variable: ZDEBTRACKING4 
Coefficients $^{a}$

\begin{tabular}{|c|c|c|c|c|c|c|c|}
\hline \multirow[b]{2}{*}{ Model } & \multicolumn{2}{|c|}{$\begin{array}{c}\text { Unstandardized } \\
\text { Coefficients } \\
\end{array}$} & \multirow[t]{2}{*}{$\begin{array}{l}\text { Standardized } \\
\text { Coefficients }\end{array}$} & \multirow[b]{2}{*}{$t$} & \multirow[b]{2}{*}{ Sig. } & \multicolumn{2}{|c|}{$\begin{array}{c}95.0 \% \text { Confidence } \\
\text { Interval for B }\end{array}$} \\
\hline & B & Std. Error & & & & $\begin{array}{l}\text { Lower } \\
\text { Bound }\end{array}$ & $\begin{array}{l}\text { Upper } \\
\text { Bound }\end{array}$ \\
\hline 1 (Constant) & -.008 & .115 & & -.073 & .942 & -.238 & .221 \\
\hline ZIDEOLOGY & -.129 & .124 & -.130 & & .302 & -.376 & .118 \\
\hline ZINTERNATIONALISM & .078 & .124 & .078 & .629 & .531 & -.169 & .326 \\
\hline ZANTI_AMERICANISM & -.078 & .123 & -.079 & -.636 & .527 & -.324 & .167 \\
\hline 2 (Constant) & .008 & .070 & & .117 & .907 & -.132 & .149 \\
\hline ZIDEOLOGY & -.029 & .077 & -.030 & -.381 & .704 & -.182 & .123 \\
\hline ZINTERNATIONALISM & .076 & .077 & .076 & .991 & .325 & -.077 & .229 \\
\hline ZANTI_AMERICANISM & .004 & .076 & .004 & .047 & .963 & -.148 & .156 \\
\hline ZFILM & -.326 & .072 & -.326 & & .000 & -.469 & -.183 \\
\hline ZDEBTRACKING3 & .710 & .073 & .704 & 9.691 & .000 & .564 & .857 \\
\hline 3 (Constant) & .003 & .072 & & .042 & .967 & -.141 & .147 \\
\hline ZIDEOLOGY & -.026 & .082 & -.027 & -.320 & .750 & -.190 & .137 \\
\hline ZINTERNATIONALISM & .079 & .080 & .079 & .985 & .328 & -.081 & .238 \\
\hline ZANTI_AMERICANISM & -.008 & .081 & -.008 & -.102 & .919 & -.169 & .153 \\
\hline ZFILM & -.326 & .073 & -.326 & & .000 & -.472 & -.181 \\
\hline ZDEBTRACKING3 & .700 & .077 & .694 & 9.131 & .000 & .547 & .853 \\
\hline ZFILMXZIDEOLOGY & .016 & .083 & .016 & .189 & .850 & -.150 & .181 \\
\hline ZFILMXZINTERNATIONALISM & .035 & .082 & .035 & .433 & .666 & -.127 & .198 \\
\hline ZFILMXZANTI_AMERICANISM & -.045 & .082 & -.045 & -.545 & .588 & -.209 & .119 \\
\hline
\end{tabular}

a. Dependent Variable: ZDEBTRACKING4 


\section{Hypothesis 4d}

\begin{tabular}{|c|c|c|c|c|c|c|c|c|c|c|}
\hline \multirow[b]{3}{*}{ Model } & \multirow[b]{3}{*}{$\mathrm{R}$} & \multicolumn{8}{|c|}{ Model Summary } & \multirow[b]{3}{*}{$\begin{array}{l}\text { Durbin- } \\
\text { Watson }\end{array}$} \\
\hline & & \multirow[b]{2}{*}{$\begin{array}{c}\mathrm{R} \\
\text { Square }\end{array}$} & \multirow[b]{2}{*}{$\begin{array}{c}\text { Adjusted R } \\
\text { Square }\end{array}$} & \multirow[b]{2}{*}{$\begin{array}{l}\text { Std. Error of } \\
\text { the Estimate }\end{array}$} & \multicolumn{5}{|c|}{ Change Statistics } & \\
\hline & & & & & $\begin{array}{c}\text { R Square } \\
\text { Change }\end{array}$ & $\begin{array}{c}F \\
\text { Change }\end{array}$ & df1 & df2 & $\begin{array}{c}\text { Sig. F } \\
\text { Change }\end{array}$ & \\
\hline 1 & $.394^{\mathrm{a}}$ & .155 & .121 & .921 & .155 & 4.523 & 3 & 74 & .006 & \\
\hline 2 & $.705^{b}$ & .497 & .462 & .720 & .342 & 24.511 & 2 & 72 & .000 & \\
\hline 3 & $.734^{\circ}$ & .539 & .486 & .704 & .042 & 2.097 & 3 & 69 & .108 & 2.062 \\
\hline
\end{tabular}

a. Predictors: (Constant), ZANTI_AMERICANISM, ZINTERNATIONALISM, ZIDEOLOGY

b. Predictors: (Constant), ZANTI_AMERICANISM, ZINTERNATIONALISM, ZIDEOLOGY, ZFILM, ZMICROSATS3

c. Predictors: (Constant), ZANTI_AMERICANISM, ZINTERNATIONALISM, ZIDEOLOGY, ZFILM, ZMICROSATS3, ZFILMXZINTERNATIONALISM, ZFILMXZANTI_AMERICANISM, ZFILMXZIDEOLOGY d. Dependent Variable: ZMICROSATS4

ANOVA $^{\mathrm{d}}$

\begin{tabular}{|c|c|c|c|c|c|c|}
\hline & & $\begin{array}{l}\text { Sum of } \\
\text { Squares }\end{array}$ & df & $\begin{array}{l}\text { Mean } \\
\text { Square }\end{array}$ & $\mathrm{F}$ & Sig. \\
\hline 1 & $\begin{array}{l}\text { Regression } \\
\text { Residual } \\
\text { Total }\end{array}$ & $\begin{array}{l}11.512 \\
62.784 \\
74.296\end{array}$ & $\begin{array}{r}3 \\
74 \\
77\end{array}$ & $\begin{array}{r}3.837 \\
.848\end{array}$ & 4.523 & $.006^{a}$ \\
\hline 2 & $\begin{array}{l}\text { Regression } \\
\text { Residual } \\
\text { Total }\end{array}$ & $\begin{array}{l}36.943 \\
37.353 \\
74.296\end{array}$ & $\begin{array}{r}5 \\
72 \\
77 \\
\end{array}$ & $\begin{array}{r}7.389 \\
.519\end{array}$ & 14.242 & $.000^{b}$ \\
\hline 3 & $\begin{array}{l}\text { Regression } \\
\text { Residual } \\
\text { Total }\end{array}$ & $\begin{array}{l}40.065 \\
34.231 \\
74.296\end{array}$ & $\begin{array}{r}8 \\
69 \\
77\end{array}$ & $\begin{array}{r}5.008 \\
.496\end{array}$ & 10.095 & $.000^{c}$ \\
\hline
\end{tabular}

a. Predictors: (Constant), ZANTI_AMERICANISM, ZINTERNATIONALISM, ZIDEOLOGY

b. Predictors: (Constant), ZANTI_AMERICANISM, ZINTERNATIONALISM, ZIDEOLOGY, ZFILM, ZMICROSATS3

c. Predictors: (Constant), ZANTI_AMERICANISM, ZINTERNATIONALISM, ZIDEOLOGY, ZFILM, ZMICROSATS3, ZFILMXZINTERNATIONALISM, ZFILMxZANTI_AMERICANISM, ZFILMXZIDEOLOGY 
Model Summary

\begin{tabular}{|c|c|c|c|c|c|c|c|c|c|c|}
\hline \multirow[b]{2}{*}{ Model } & \multirow[b]{2}{*}{$\mathrm{R}$} & \multirow[b]{2}{*}{$\begin{array}{c}\mathrm{R} \\
\text { Square }\end{array}$} & \multirow[b]{2}{*}{$\begin{array}{c}\text { Adjusted R } \\
\text { Square }\end{array}$} & \multirow[b]{2}{*}{$\begin{array}{l}\text { Std. Error of } \\
\text { the Estimate }\end{array}$} & \multicolumn{5}{|c|}{ Change Statistics } & \multirow[b]{2}{*}{$\begin{array}{l}\text { Durbin- } \\
\text { Watson }\end{array}$} \\
\hline & & & & & $\begin{array}{c}\text { R Square } \\
\text { Change }\end{array}$ & $\begin{array}{c}\mathrm{F} \\
\text { Change }\end{array}$ & df1 & df2 & $\begin{array}{c}\text { Sig. F } \\
\text { Change }\end{array}$ & \\
\hline 1 & $.394^{a}$ & .155 & .121 & .921 & .155 & 4.523 & 3 & 74 & .006 & \\
\hline 2 & $.705^{b}$ & .497 & .462 & .720 & .342 & 24.511 & 2 & 72 & .000 & \\
\hline 3 & $.734^{c}$ & .539 & .486 & .704 & .042 & 2.097 & 3 & 69 & .108 & 2.062 \\
\hline
\end{tabular}

a. Predictors: (Constant), ZANTI_AMERICANISM, ZINTERNATIONALISM, ZIDEOLOGY

b. Predictors: (Constant), ZANTI_AMERICANISM, ZINTERNATIONALISM, ZIDEOLOGY, ZFILM, ZMICROSATS3

c. Predictors: (Constant), ZANTI_AMERICANISM, ZINTERNATIONALISM, ZIDEOLOGY, ZFILM, ZMICROSATS3, ZFILMXZINTERNATIONALISM, ZFILMXZANTI_AMERICANISM, ZFILMXZIDEOLOGY

d. Dependent Variable: ZMICROSATS4 
Coefficients $^{\mathrm{a}}$

\begin{tabular}{|c|c|c|c|c|c|c|c|}
\hline \multirow[b]{2}{*}{ Model } & \multicolumn{2}{|c|}{$\begin{array}{l}\text { Unstandardized } \\
\text { Coefficients }\end{array}$} & $\begin{array}{l}\text { Standardized } \\
\text { Coefficients }\end{array}$ & \multirow[b]{2}{*}{$t$} & \multirow[b]{2}{*}{ Sig. } & \multicolumn{2}{|c|}{$\begin{array}{c}95.0 \% \text { Confidence } \\
\text { Interval for B }\end{array}$} \\
\hline & B & Std. Error & Beta & & & $\begin{array}{l}\text { Lower } \\
\text { Bound }\end{array}$ & $\begin{array}{l}\text { Upper } \\
\text { Bound }\end{array}$ \\
\hline 1 (Constant) & .028 & .104 & & .264 & .793 & -.180 & .235 \\
\hline ZIDEOLOGY & -.323 & .113 & -.331 & - & .006 & -.549 & -.098 \\
\hline ZINTERNATIONALISM & .181 & .112 & .185 & 1.622 & .109 & -.041 & .403 \\
\hline ZANTI_AMERICANISM & -.165 & .112 & -.169 & $\begin{array}{r}- \\
1.472\end{array}$ & .145 & -.389 & .058 \\
\hline 2 (Constant) & .014 & .082 & & 172 & .864 & -.149 & .177 \\
\hline ZIDEOLOGY & -.194 & .091 & -.198 & & .036 & -.374 & -.013 \\
\hline ZINTERNATIONALISM & .235 & .088 & .241 & 2.670 & .009 & .060 & .411 \\
\hline ZANTI_AMERICANISM & -.074 & .089 & -.076 & -.836 & .406 & -.251 & .103 \\
\hline ZFILM & -.006 & .083 & -.006 & -.068 & .946 & -.171 & .160 \\
\hline ZMICROSATS3 & .622 & .089 & .623 & 6.979 & .000 & .444 & .799 \\
\hline 3 (Constant) & -.002 & .080 & & -.022 & .983 & -.162 & .158 \\
\hline ZIDEOLOGY & -.233 & .094 & -.239 & & .015 & -.420 & -.046 \\
\hline ZINTERNATIONALISM & .273 & .088 & .280 & 3.110 & .003 & .098 & .449 \\
\hline ZANTI_AMERICANISM & -.084 & .090 & -.086 & -.934 & .354 & -.263 & .095 \\
\hline ZFILM & -.004 & .081 & -.004 & -.048 & .962 & -.166 & .158 \\
\hline ZMICROSATS3 & .578 & .089 & .579 & 6.506 & .000 & .401 & .755 \\
\hline ZFILMXZIDEOLOGY & -.118 & .094 & -.120 & & .211 & -.305 & .069 \\
\hline ZFILMXZINTERNATIONALISM & .199 & .090 & .201 & 2.205 & .031 & .019 & .379 \\
\hline ZFILMxZANTI_AMERICANISM & -.095 & .091 & -.097 & $\begin{array}{r}- \\
1.048\end{array}$ & .298 & -.276 & .086 \\
\hline
\end{tabular}

a. Dependent Variable: ZMICROSATS4 


\section{Hypothesis 5}

\section{Model Summary ${ }^{d}$}

\begin{tabular}{|c|c|c|c|c|c|c|c|c|c|c|}
\hline \multirow[b]{2}{*}{ Model } & \multirow[b]{2}{*}{$\mathrm{R}$} & \multirow[b]{2}{*}{$\begin{array}{c}\mathrm{R} \\
\text { Square }\end{array}$} & \multirow[b]{2}{*}{$\begin{array}{c}\text { Adjusted R } \\
\text { Square }\end{array}$} & \multirow[b]{2}{*}{$\begin{array}{l}\text { Std. Error of } \\
\text { the Estimate }\end{array}$} & \multicolumn{5}{|c|}{ Change Statistics } & \multirow[b]{2}{*}{$\begin{array}{l}\text { Durbin- } \\
\text { Watson }\end{array}$} \\
\hline & & & & & $\begin{array}{c}\text { R Square } \\
\text { Change }\end{array}$ & $\begin{array}{c}F \\
\text { Change }\end{array}$ & df1 & df2 & $\begin{array}{c}\text { Sig. F } \\
\text { Change }\end{array}$ & \\
\hline 1 & $330^{\mathrm{a}}$ & .109 & .073 & .969 & .109 & 3.006 & 3 & 74 & .036 & \\
\hline 2 & $.736^{b}$ & .542 & .510 & .705 & .433 & 34.014 & 2 & 72 & .000 & \\
\hline 3 & $.752^{\circ}$ & .565 & .515 & .701 & .023 & 1.234 & 3 & 69 & .304 & 2.043 \\
\hline
\end{tabular}

a. Predictors: (Constant), ZANTI_AMERICANISM, ZINTERNATIONALISM, ZIDEOLOGY

b. Predictors: (Constant), ZANTI_AMERICANISM, ZINTERNATIONALISM, ZIDEOLOGY, ZFILM, ZSPACEPOLICY

c. Predictors: (Constant), ZANTI_AMERICANISM, ZINTERNATIONALISM, ZIDEOLOGY, ZFILM, ZSPACEPOLICY, ZFILMXZANTI_AMERICANISM, ZFILMXZINTERNATIONALISM, ZFILMXZIDEOLOGY

d. Dependent Variable: ZSPACEPOLICY2

ANOVA $^{\mathrm{d}}$

\begin{tabular}{|c|c|c|c|c|c|c|}
\hline & & $\begin{array}{l}\text { Sum of } \\
\text { Squares }\end{array}$ & df & $\begin{array}{l}\text { Mean } \\
\text { Square }\end{array}$ & $F$ & Sig. \\
\hline 1 & $\begin{array}{l}\text { Regression } \\
\text { Residual } \\
\text { Total }\end{array}$ & $\begin{array}{r}8.474 \\
69.523 \\
77.996 \\
\end{array}$ & $\begin{array}{r}3 \\
74 \\
77 \\
\end{array}$ & $\begin{array}{r}2.825 \\
.939\end{array}$ & 3.006 & $.036^{\mathrm{a}}$ \\
\hline 2 & $\begin{array}{l}\text { Regression } \\
\text { Residual } \\
\text { Total }\end{array}$ & $\begin{array}{l}42.249 \\
35.747 \\
77.996\end{array}$ & $\begin{array}{r}5 \\
72 \\
77 \\
\end{array}$ & $\begin{array}{r}8.450 \\
.496\end{array}$ & 17.019 & $.000^{\mathrm{b}}$ \\
\hline 3 & $\begin{array}{l}\text { Regression } \\
\text { Residual } \\
\text { Total }\end{array}$ & $\begin{array}{l}44.069 \\
33.928 \\
77.996\end{array}$ & $\begin{array}{r}8 \\
69 \\
77\end{array}$ & $\begin{array}{r}5.509 \\
.492\end{array}$ & 11.203 & $.000^{\circ}$ \\
\hline
\end{tabular}

a. Predictors: (Constant), ZANTI_AMERICANISM, ZINTERNATIONALISM, ZIDEOLOGY

b. Predictors: (Constant), ZANTI_AMERICANISM, ZINTERNATIONALISM, ZIDEOLOGY, ZFILM, ZSPACEPOLICY

c. Predictors: (Constant), ZANTI_AMERICANISM, ZINTERNATIONALISM, ZIDEOLOGY, ZFILM, ZSPACEPOLICY, ZFILMXZANTI_AMERICANISM, ZFILMXZINTERNATIONALISM,

ZFILMXZIDEOLOGY 


\begin{tabular}{|c|c|c|c|c|c|c|c|c|c|c|}
\hline \multirow[b]{3}{*}{ Model } & \multicolumn{9}{|c|}{ Model Summary ${ }^{d}$} & \multirow[b]{3}{*}{$\begin{array}{l}\text { Durbin- } \\
\text { Watson }\end{array}$} \\
\hline & & & & & \multicolumn{5}{|c|}{ Change Statistics } & \\
\hline & $\mathrm{R}$ & $\begin{array}{c}R \\
\text { Square }\end{array}$ & $\begin{array}{c}\text { Adjusted R } \\
\text { Square }\end{array}$ & $\begin{array}{l}\text { Std. Error of } \\
\text { the Estimate }\end{array}$ & $\begin{array}{c}\text { R Square } \\
\text { Change }\end{array}$ & $\begin{array}{c}F \\
\text { Change }\end{array}$ & df1 & df2 & $\begin{array}{c}\text { Sig. F } \\
\text { Change }\end{array}$ & \\
\hline 1 & $.330^{\mathrm{a}}$ & .109 & .073 & .969 & .109 & 3.006 & 3 & 74 & .036 & \\
\hline 2 & $.736^{\mathrm{b}}$ & .542 & .510 & .705 & .433 & 34.014 & 2 & 72 & .000 & \\
\hline 3 & $.752^{c}$ & .565 & .515 & .701 & .023 & 1.234 & 3 & 69 & .304 & 2.043 \\
\hline
\end{tabular}

a. Predictors: (Constant), ZANTI_AMERICANISM, ZINTERNATIONALISM, ZIDEOLOGY

b. Predictors: (Constant), ZANTI_AMERICANISM, ZINTERNATIONALISM, ZIDEOLOGY, ZFILM, ZSPACEPOLICY

c. Predictors: (Constant), ZANTI_AMERICANISM, ZINTERNATIONALISM, ZIDEOLOGY, ZFILM, ZSPACEPOLICY, ZFILMXZANTI_AMERICANISM, ZFILMXZINTERNATIONALISM, ZFILMXZIDEOLOGY

d. Dependent Variable: ZSPACEPOLICY2 
Coefficients $^{a}$

\begin{tabular}{|c|c|c|c|c|c|c|c|}
\hline \multirow[b]{2}{*}{ Model } & \multicolumn{2}{|c|}{$\begin{array}{l}\text { Unstandardized } \\
\text { Coefficients }\end{array}$} & $\begin{array}{l}\text { Standardized } \\
\text { Coefficients }\end{array}$ & \multirow[b]{2}{*}{$t$} & \multirow[b]{2}{*}{ Sig. } & \multicolumn{2}{|c|}{$\begin{array}{l}95.0 \% \text { Confidence } \\
\text { Interval for B }\end{array}$} \\
\hline & B & Std. Error & Beta & & & $\begin{array}{l}\text { Lower } \\
\text { Bound }\end{array}$ & $\begin{array}{l}\text { Upper } \\
\text { Bound }\end{array}$ \\
\hline 1 (Constant) & .002 & .110 & & .018 & .985 & -.217 & .221 \\
\hline ZIDEOLOGY & -.351 & .119 & -.351 & -2.942 & .004 & -.588 & -.113 \\
\hline ZINTERNATIONALISM & .131 & .117 & .131 & 1.119 & .267 & -.103 & .365 \\
\hline ZANTI_AMERICANISM & .032 & .118 & .032 & .274 & .785 & -.203 & .268 \\
\hline 2 (Constant) & .003 & .080 & & .039 & .969 & -.156 & .162 \\
\hline ZIDEOLOGY & -.325 & .087 & -.325 & -3.734 & .000 & -.499 & -.152 \\
\hline ZINTERNATIONALISM & .041 & .086 & .041 & .471 & .639 & -.131 & .212 \\
\hline ZANTI_AMERICANISM & .100 & .087 & .100 & 1.151 & .253 & -.073 & .273 \\
\hline ZFILM & .503 & .084 & .500 & 5.983 & .000 & .336 & .671 \\
\hline ZSPACEPOLICY & 319 & .084 & .320 & 3.787 & .000 & .151 & .487 \\
\hline 3 (Constant) & .013 & .080 & & .161 & .873 & -.147 & .172 \\
\hline ZIDEOLOGY & -.304 & .091 & -.304 & -3.341 & .001 & -.486 & -.123 \\
\hline ZINTERNATIONALISM & .008 & .087 & .008 & .087 & .931 & -.167 & .182 \\
\hline ZANTI_AMERICANISM & .094 & .091 & .094 & 1.031 & .306 & -.088 & .275 \\
\hline ZFILM & .510 & .084 & .507 & 6.053 & .000 & .342 & .679 \\
\hline ZSPACEPOLICY & .299 & .090 & .301 & 3.310 & .001 & .119 & .479 \\
\hline ZFILMxZIDEOLOGY & .115 & .098 & .114 & 1.172 & .245 & -.081 & .310 \\
\hline ZFILMxZINTERNATIONALISM & -.130 & .089 & -.129 & -1.468 & .147 & -.308 & .047 \\
\hline ZFILMxZANTI_AMERICANISM & .067 & 091 & .066 & .736 & .464 & -.114 & .247 \\
\hline
\end{tabular}

a. Dependent Variable: ZSPACEPOLICY2 